UNIVERSIDADE DE SÃO PAULO

ESCOLA DE ENFERMAGEM

EUGÊNIA ZILIOLI DE ALMEIDA

AS CONCEPÇÕES DO AGENTE COMUNITÁRIO DE SAÚDE SOBRE PROMOÇÃO DA SAÚDE

SÃO PAULO

2008 


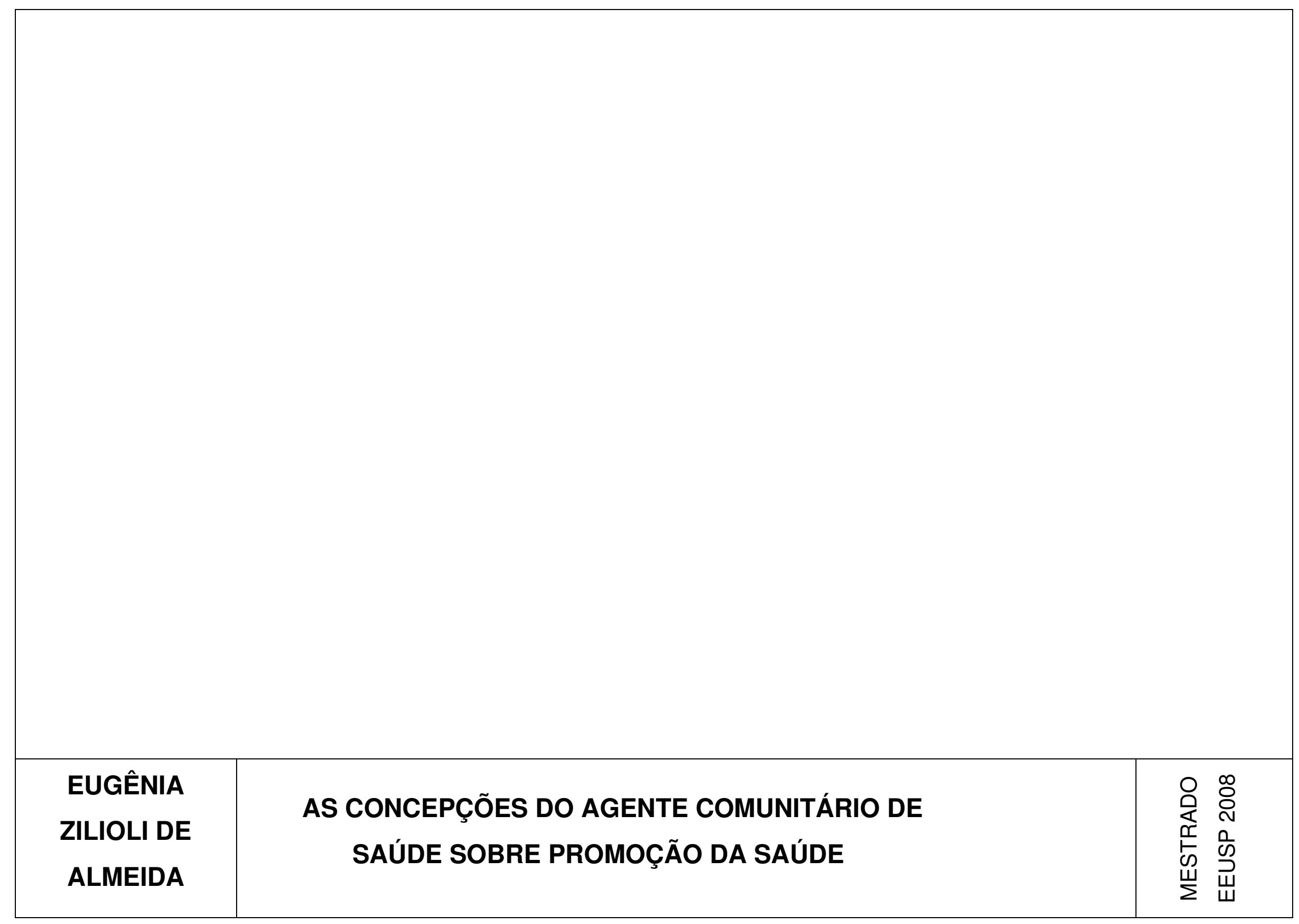




\section{AS CONCEPÇÕES DO AGENTE COMUNITÁRIO DE SAÚDE SOBRE PROMOÇÃO DA SAÚDE}

Dissertação de Mestrado apresentada ao Departamento de Saúde Coletiva da Escola de Enfermagem da Universidade de São Paulo para obtenção de grau de Mestre

Orientadora:

Prof ${ }^{a}$ Dra Lislaine Aparecida Fracolli 
AUTORIZO A REPRODUÇÃO E DIVULGAÇÃO TOTAL OU PARCIAL DESTE TRABALHO, POR QUALQUER MEIO CONVENCIONAL OU ELETRÔNICO, PARA FINS DE ESTUDO E PESQUISA, DESDE QUE CITADA A FONTE.

FICHA CATALOGRÁFICA

Almeida, Eugênia Zilioli de

As concepções do agente comunitário de saúde sobre promoção da saúde./ Eugênia Zilioli de Almeida. - São Paulo, 2008.

$117 \mathrm{p}$.

Dissertação (Mestrado) - Escola de Enfermagem da Universidade de São Paulo.

Orientadora: $\operatorname{Prof}^{\underline{a}} \operatorname{Dr}^{\underline{a}}$ Lislaine Aparecida Fracolli

1. Agente Comunitário de Saúde 2. Promoção da Saúde 3. Saúde Coletiva 
Nome: Eugênia Zilioli de Almeida

Título: As concepções do agente comunitário de saúde sobre promoção da saúde.

Dissertação de Mestrado apresentada ao Departamento de Saúde Coletiva da Escola de Enfermagem da Universidade de São

Paulo para obtenção de grau de Mestre.

Aprovado em:

Banca examinadora:

Prof. Dr. Instituição:

Julgamento: Assinatura:

Prof. Dr. Instituição:

Julgamento: Assinatura:

Prof. Dr. Instituição:

Julgamento: Assinatura:

Prof. Dr. Instituição:

Julgamento: Assinatura: 


\section{DEDICATÓRIA}

Ao meu querido Pai, em memória, por proporcionar meu ingresso aos estudos e esforçar-se para efetivar meu valor.

À minha Mãe, que se dedicou a conduzir-me para o crescimento profissional.

Ao Saulo, esposo querido, companheiro de todos os momentos, pela compreensão, companheirismo e carinho ao longo do período de elaboração deste trabalho.

A minha filha querida Marina, presença diária de amor e motivação.

Aos meus irmãos Estêvão, Geraldinho e Paulo e minhas irmãs Márcia, Luck, Dani e Soninha, juntamente com minha cunhada Gláucia e cunhados Serginho, Rogério, Cleber e Carlos, por compreenderem minhas faltas neste longo período de dedicação aos estudos.

A todos os meus queridos sobrinhos, alegria da minha vida. 


\section{AGRADECIMENTOS}

À orientadora e amiga, Prof. ${ }^{a}$ Dr. ${ }^{\underline{a}}$ Lislaine Aparecida Fracolli, pela competência e respeito com que conduziu este processo, do alvorecer da idéia até a sua síntese.

As Professoras Dra..$^{-}$, Renata Ferreira Takahashi e Dr. ${ }^{a}$ Maria De La Ó Veríssimo, pelas valiosas contribuições no Exame de Qualificação.

À Prof. a Anna Maria Chiesa, que carinhosamente me mostrou o caminho da pesquisa em enfermagem.

Aos meus queridos amigos, que acompanharam e tornaram possível minha trajetória desde muito: Ricardo Vilela e Eduardo Jorge de Sousa Cruz.

Ao amigo Tony Wendell Paulino da Fonseca pelo carinho e dedicação com que se dispões a transmitir e auxiliar seus conhecimentos na parte computacional.

A todos os colegas de trabalho das equipes de PSF da UBS Humaitá, em especial aos Agentes Comunitários de Saúde, que gentilmente participaram desta pesquisa.

À Supervisão de Saúde Sé do município de São Paulo, pelo apoio fundamental prestado a minha pesquisa.

Aos familiares, amigos e todos aqueles que estiveram enviando apoio e energia positiva, além da paciência em entender e aceitar tantos momentos ausentes. 
O homem se modifica por não ser uma mônada: ele é aberto. Por ser aberto é capaz de responder, ao invés de simplesmente reagir. O reagir é um ato que se localiza na esfera do biológico. O responder, contudo, pertence a esfera da liberdade. O homem responde por que descobre o seu mundo como se fosse uma mensagem a ele endereçada, como um horizonte em direção ao qual pode se projetar. $E$ ao responder, o mundo torna-se diferente: torna-se histórico.

Rubem Alves (1987) 
Almeida EZ. As concepções do Agente Comunitário de Saúde sobre Promoção da Saúde. [dissertação]. São Paulo: Escola de Enfermagem, Universidade de São Paulo: 2008.

\section{RESUMO}

Esta pesquisa compreende um estudo de caso do tipo descritivo, que pretende fazer uma abordagem quanti-qualitativa das ações de Promoção da Saúde do Agente Comunitário de Saúde (ACS). Teve como objetivos: descrever e analisar as ações do ACS, buscando identificar as concepções de promoção da saúde que dão suporte as mesmas. A pesquisa foi realizada na cidade de São Paulo, em uma Unidade Básica de Saúde localizada na região central deste município. Foram sujeitos do estudo 16 ACS que atuam na região. Os dados quantitativos foram coletados através de um Formulário, baseado na proposta do Ministério da Saúde para os eixos de Competências do ACS quais sejam aqui citados como: A integração da equipe com a população, Planejamento e avaliação, Promoção da Saúde, Prevenção e monitoramento de risco ambiental e sanitário e a grupos específicos e morbidades. Estes dados foram organizados segundo o programa EXCEL. Os dados qualitativos foram coletados por meio da técnica de Grupo Focal (GF) e visavam aprofundar os dados obtidos com o inquérito. As discussões das ações de promoção da saúde no GF foram analisadas pelo método do Discurso do Sujeito Coletivo (DSC). Foi possível a constatação de que o ACS investigado tinha mais habilidade com as ações de promoção da saúde que se dispunham informar a família sobre o comportamento adequado à saúde e, pouquíssimo domínio, em desenvolver a autonomia da população para tomada de decisão em relação as suas necessidades de saúde, e revelaram três Discursos Centrais: O trabalho do ACS, O desenvolvimento de atividades inter-setoriais na comunidade para o ACS e A valorização das ações do ACS para a comunidade. A análise destes discursos mostrou que as práticas de promoção da saúde do ACS, estão centradas numa visão higienista e não de empowerment. Os resultados mostram que a capacitação contínua, não considerou o embasamento teórico do novo modelo da Promoção da Saúde. Com isso, o ACS não compreendeu ainda qual é seu real papel e tão pouco desempenhou ações que auxiliassem no desenvolvimento da autonomia da população. A proposta deste trabalho é que sejam garantidos momentos de discussão entre as equipes de PSF, baseados teoricamente nos eixos de competências dos ACS e com isso, este profissional (ACS) terá a possibilidade de compreender seu real papel e poderá desenvolver ações cotidianas que capacitem e estimulem a população a participar no levantamento de suas necessidades e na organização de propostas para solucionar seus problemas de saúde.

Unitermos: Agente Comunitário de Saúde, Promoção da Saúde, Saúde Coletiva. 
Almeida EZ. Conceptions of health's community Work concerning Health Promotion. [dissertação]. São Paulo: Escola de Enfermagem, Universidade de São Paulo: 2008.

\section{ABSTRACT}

This research comprises a descriptive case study which intends to make a quantitative and qualitative approach of health promotion actions of community health Work (CHW). It aims to describe and analyze their actions, trying to identify the conceptions of health promotion which support them. The research took place in a Basic Health located downtown in Sao Paulo city and sixteen (16) community health work have been subject of study. Quantitative data were collected through a special form based on the proposal by Health Ministry to the axes of competences of CHW, such as the integration of the team with population, planning and evaluation, health promotion, prevention and monitoring of environmental and sanitary risk and to specific groups and illnesses. These data were organized by using the EXCEL program. Qualitative data were collected by using a focal group technique and aimed to deepen the results obtained with the investigation. The discussions on health promotion actions in the focal group were analyzed through the colective subject discourse method. According to the results, it was possible to verify that the analyzed workers had more ability to deal with health promotion actions which aimed to inform the family about a proper behavior related to health and very little competence in developing population autonomy regarding their health necessities. The discussion revealed three central discourses: the work of health's community work, the development of inter-sectoral activities in the community for the CHW, and the valuation of their actions for the community. The analysis of these discourses showed that the practices of health promotion of health's community work are focused on an hygienist view and not empowerment. The results have shown that the training of health's community work did not consider the theoretical basis of the new model of health promotion. Thus, the community health work have not understood what their real role is, and either have performed actions which promote the autonomy of the population. The purpose of this work is guarantee moments of discussion among the Family Health Program teams, theoretically based on the axes of competence of health's community work, in order to give to these professionals an opportunity to understand they real role, as well as to develop daily actions which allow population a greater participation in knowing their needs and organize proposals to solve their health problems.

Key Words: Health Community Agent, Health Promotion, Collective Health 


\section{LISTA DE ILUSTRAÇÕES}

Gráfico 1 - Faixa etária dos sujeitos desta pesquisa (ACS) . ..................................40

Gráfico 2 - Escolaridade dos sujeitos desta pesquisa (ACS). ............................... 40

Gráfico 3 - Renda familiar do sujeito desta pesquisa (ACS) . ................................. 44

Gráfico 4 - Pessoas que vivem com a renda familiar do ACS.................................. 45

Gráfico 5 - $O$ conjunto de ações de integração da equipe com a população local.(1 ${ }^{\circ}$ eixo de competências do ACS)....................................................................... 49

Gráfico 6 - Refere-se a ação de expor a opinião do ACS nas reuniões em equipe (esta ação pertence ao $1^{\circ}$ eixo de competências do ACS).

Gráfico 7 - O conjunto de ações de Planejamento e avaliação (2º eixo de competências do ACS).

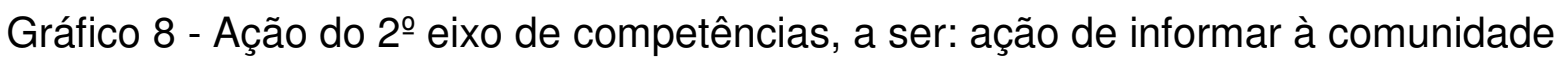
os resultados obtidos no levantamento sobre a saúde da população.

Gráfico 9 - Conjunto de ações de Promoção da Saúde (3ํexo de competências do ACS).

Gráfico 10 - 1aㅗ Ação de Promoção da Saúde: identifica a relação entre problemas de saúde e condição de vida.

Gráfico 11 - $2^{\mathrm{a}}$ ação de Promoção da Saúde: identifica exemplos positivos que promovem a saúde da comunidade.

Gráfico 12 - $3^{\mathrm{a}}$ ação de Promoção da Saúde: realiza atividades educativas para a comunidade (palestras, campanhas, mutirões, etc) juntamente com o enfermeiro... 56 Gráfico 13 - 4⿳a ação de Promoção da Saúde: realiza atividades educativas com outro ACS.

Gráfico 14 - 5a ação de Promoção da Saúde: realiza atividades educativas para a comunidade sozinho.

Gráfico 15 - 6ª ação de Promoção da Saúde: utiliza recursos de informação e comunicação (faixas, panfletos, etc) adequados à realidade local.

Gráfico 16 - 7ª ação de Promoção da Saúde: estimula os indivíduos e comunidade a refletirem sobre as suas condições de saúde e doença.

Gráfico 17 - 8ª ação de Promoção da Saúde: orienta os indivíduos quanto ao auto cuidado 
Gráfico 18 - 9aa ação de Promoção da Saúde: orienta quanto a medidas de proteção à saúde(alimentação, higiene pessoal, limpeza, acondicionamento e destino do lixo, cuidados com a água e dejetos, e outros.

Gráfico 19 - 10ª ação de Promoção da Saúde: orienta indivíduos e família quanto as medidas de prevenção de acidades domésticos.

Gráfico 20 - 11aㅡ ação de Promoção da Saúde: propõem ações que utilizem as diversas secretarias existentes no município.

Gráfico 21 - 12ª ação de Promoção da Saúde: executa ações que atuam em parceria com outras Secretarias existentes no município.

Gráfico 22 - 13ª ação de Promoção da Saúde: estabelece parcerias com creches, asilos, escolas, comércios, grupos sociais e outros.

Gráfico 23 - 14ª ação de Promoção da Saúde: orienta a família e ou portador de necessidades especiais quanto às medidas facilitadoras para a sua máxima inclusão social.

Gráfico 24 - 15a ação de Promoção da Saúde: apóia ações de alfabetização de crianças, adolescentes, jovens e adultos.

Gráfico 25 - 16 ação de Promoção da Saúde: participa de reuniões do conselho local de saúde ou de outro conselho local.

Gráfico 26 - 4ํㅡㄹ Eixo de Competência do ACS: Prevenção e monitoramento de risco ambiental e sanitário.

Gráfico 27 - 1aa ação do $4^{\circ}$ eixo de Competências do ACS: identificam as condições ambientais e sanitárias que provoquem riscos para a saúde da comunidade. Gráfico 28 - $2^{\underline{a}}$ ação do $4^{\circ}$ eixo de competências do ACS: informa à equipe de saúde sobre a ocorrência de situação de risco, na micro-área de atuação.

Gráfico 29 - 3ํaa aço do $4^{\circ}$ eixo de competência do ACS: informa à população sobre a ocorrência de situações de risco, na micro-área de atuação.

Gráfico 30 - 4ª ação do 4ํㅜㄹ eixo de competências do ACS: orienta indivíduos e grupos quanto a medidas de redução ou prevenção de riscos ambientais e sanitários em saúde. 74

Gráfico 31 - 5o Eixo de Competência do ACS: Prevenção e monitoramento a grupos específicos e morbidades.

Gráfico 32 - 1aa ação do 5ำ eixo de competências do ACS: identifica indivíduos ou grupos que demandem cuidados especiais de saúde. 
Gráfico 33 - 2 $2^{\mathrm{a}}$ ação do $4^{\circ}$ eixo de competências do ACS: orienta a comunidade sobre os sinais que indicam problemas de saúde.

Gráfico 34 - $3^{\text {a }}$ ação do $5^{\circ}$ eixo de competências do ACS: comunica à equipe sobre os casos existentes de indivíduos ou grupos que necessitam de cuidados especiais ("grupos de risco", portadores de necessidades especiais e outros). 78 Gráfico 35 - 4⿳亠丷a ação do $5^{\circ}$ eixo de competências do ACS: ao identificar um problema de saúde nos indivíduos ou grupos, encaminha à UBS para atendimento. 79 Gráfico 36 - 5aa ação do $5^{\circ}$ eixo de competência do ACS: agenda ou remarca consultas para a comunidade

Gráfico 37 - 6⿳a ação do 5o eixo de competência do ACS: leva medicação (conforme prescrição médica ou de enfermagem) para alguém da população.

Gráfico 38 - $7^{a}$ ação do 6ํe eixo de competências do ACS: sensibiliza os familiares e seu grupo social para a convivência com os indivíduos que necessitem de cuidados especiais. 82

Gráfico 39 - 8a ação do $5^{\circ}$ eixo de competências do ACS: estimula indivíduos, familiares e grupos a participarem de programas sociais locais que envolvam orientação e prevenção da violência intra e inter-familiar. 83 Gráfico 40 - 9ª ação do $5^{\circ}$ eixo de competências do ACS: orienta as gestantes sobre os cuidados relativos à gestação. .84 


\section{LISTA DE SIGLAS}

OMS

Organização Mundial da Saúde

PACS

Programa de Agentes Comunitários da Saúde

MS

Ministério da Saúde

UTGSF

Unidade de Treinamento e Prestação de Serviços da Escola de Saúde Pública.

ACS

Agente Comunitário de Saúde

PSF

Programa Saúde da Família

UNICEF

Fundo das Nações Unidas para a Infância

DEGES

Departamento de Gestão da Educação na Saúde

ABRASCO

Associação Brasileira de Saúde Coletiva

SUS

Sistema Único de Saúde

PNPS

Política Nacional de Promoção da Saúde

SMADS

Secretaria Municipal de Assistência e Desenvolvimento Social

IC

Idéia Central

Ex-Ch

Expressão Chave

DSC

Discurso do Sujeito Coletivo 


\section{SUMÁRIO}

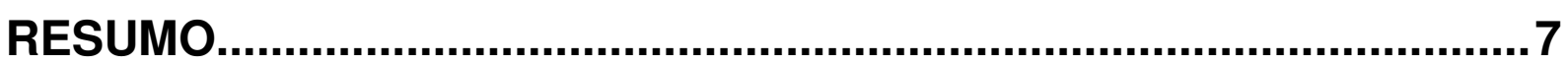

ABSTRACT

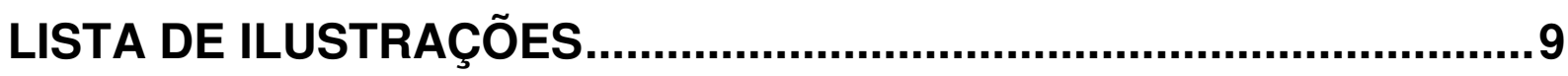

LISTA DE SIGLAS

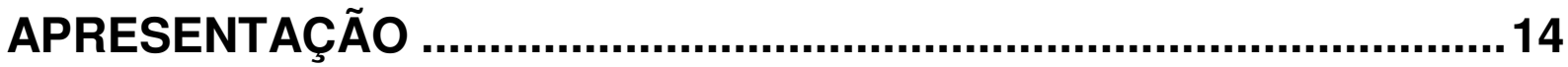

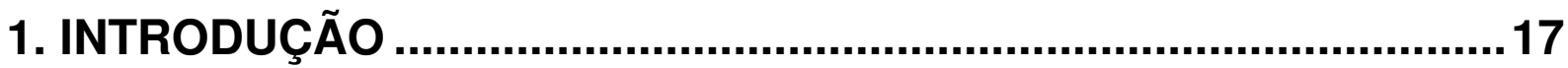

1.1 O PSF E SUAS CONTRIBUIÇÕES PARA O TRABALHO DO ACS........ 17

1.2 A REGULAMENTAÇÃO DA PRÁTICA DO ACS..................................... 20

2 OBJETIVOS

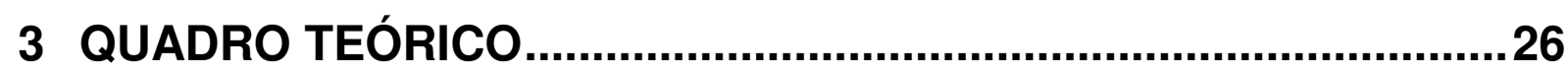

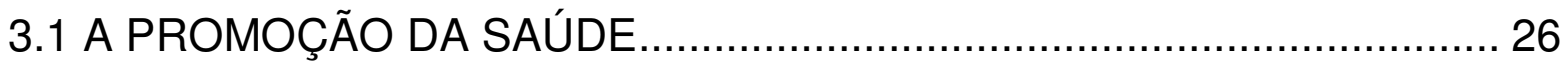

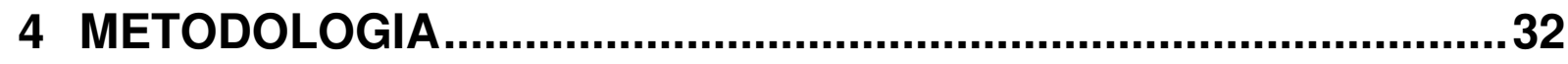

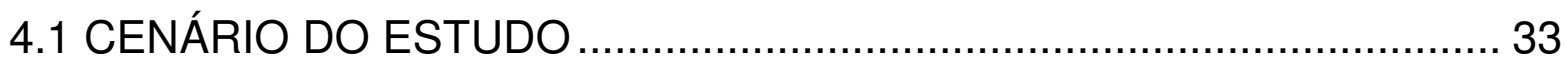

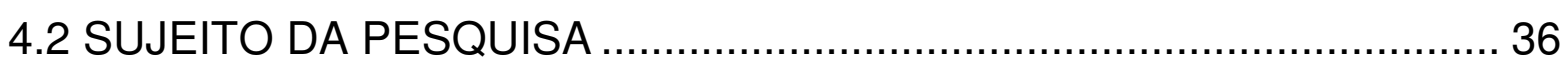

4.3 PROCEDIMENTO ÉTICO LEGAL........................................................ 36

4.4 ANÁLISE DOS DADOS ................................................................. 37

4.5 PROCEDIMENTOS E INSTRUMENTOS PARA A COLETA DE

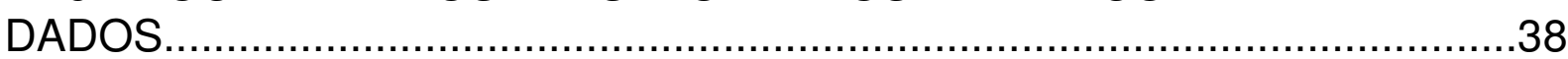

5 RESULTADOS E DISCUSSÃO....................................................40

5.1 O ACS NA UNIDADE BÁSICA DE SAÚDE: UMA BREVE CARACTERIZAÇÃO

5.2 AS COMPETÊNCIAS MAIS PRESENTES NO COTIDIANO DO ACS ... 48

5.3 AS PERCEPÇÕES DOS ACS SOBRE SUAS AÇÕES DE PROMOÇÃO DA SAÚDE

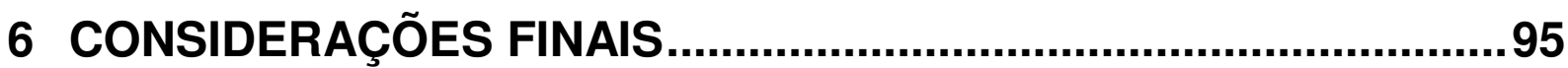

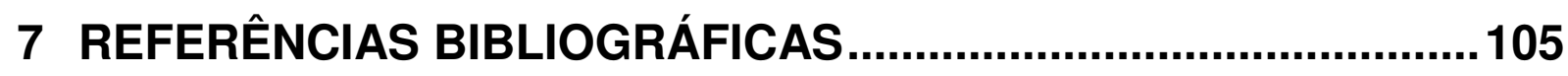

ANEXOS 


\section{APRESENTAÇÃO}

As primeiras experiências com o Programa Saúde da Família (PSF) se iniciaram no município de São Paulo, somente após seis anos da sua implantação no âmbito nacional. Tinha por desafio a reformulação do modelo tradicional de assistência à saúde junto a uma rede de aproximadamente 400 Unidades Básicas de Saúde (UBS), como também áreas descobertas de qualquer tipo de equipamento público ${ }^{(1)}$.

O PSF de São Paulo contava, em 2004, com 730 equipes e aproximadamente 4500 agentes comunitários de Saúde, o que tornava imprescindível o desenvolvimento de tecnologias que fortalecessem a atenção básica que estava sendo construída ${ }^{(1)}$.

A necessidade de dispor de instrumentos que auxiliassem o desenvolvimento de ações de promoção da saúde impulsionou técnicos e coordenadores do PSF do Município de São Paulo, a implantar o Projeto: "Nossas Crianças: Janelas de Oportunidades", apoiado pelo Fundo das Nações Unidas para a Infância (UNICEF) (2).

Tal Projeto teve como objetivo geral fortalecer as ações de promoção do desenvolvimento de crianças de 0 a 6 anos de idade, por meio da qualificação dos cuidados familiares. O envolvimento das equipes de Saúde da Família tornou possível a execução desse Projeto a partir de uma nova abordagem do tema.

A primeira Oficina, destinada à apresentação inicial do Projeto, aconteceu em abril de 2002, quando se estabeleceu também um marco para a meta de construção de parceria com os Distritos de Saúde. Nessa Oficina ocorreram exposições e debates sobre promoção da saúde e desenvolvimento infantil com a participação dos representantes das Equipes de Saúde da Família do município, indicados pelos seus gerentes $^{(3)}$.

Nessa ocasião houve ainda a apresentação dos elementos que comporiam o marco conceitual desse Projeto, quais sejam: Promoção da Saúde; Família; Rede social de apoio; Desenvolvimento Infantil: com enfoque nas oportunidades e conquistas e Competências Familiares/UNICEF, traçando, desta forma, uma 
trajetória que envolveria a constituição do grupo técnico, o alinhamento conceitual e a opção pela construção coletiva do trabalho.

Como critério para a escolha das regiões do município de São Paulo onde o projeto seria implantado, buscou-se as localidades que apresentavam um contingente maior de riscos sócio-econômicos para crianças menores de cinco anos. Promulgaram-se, então, critérios para a seleção baseados nos seguintes índices:

- $\quad$ Maior contingente de crianças menores de cinco anos;

- $\quad$ Maior incidência de partos prematuros;

- Maior incidência de gravidez na adolescência;

- Maior concentração de famílias com renda precária;

- $\quad$ Regiões de localização dos parceiros do projeto.

Na segunda Oficina foram apresentados os instrumentos do Projeto "Janelas", quais sejam: a Cartilha - "Toda Hora é Hora de Cuidar" e a Ficha de Acompanhamento. Esses materiais foram apresentados e discutidos entre os representantes do Programa Saúde da Família, os quais levantaram críticas e sugestões ${ }^{(3)}$.

Na terceira oficina fez-se o lançamento oficial desses produtos, ocasião essa em que também se formou a "rede de multiplicadores", grupo de profissionais responsáveis por "multiplicar" essa proposta para os demais membros da equipe Saúde da Família das regiões escolhidas. Esse grupo, em sua maioria, era composto, por enfermeiros e agentes comunitários indicados pelos coordenadores regionais de saúde. Para a implantação do projeto, foram capacitados ao todo 130 multiplicadores das UBS das regiões Sul, Centro-Norte e Leste da cidade de São Paulo, por meio dos quais a proposta do "Janelas" foi repassada às demais UBS da rede $^{(3)}$.

Como enfermeira e multiplicadora do "Janelas", fui responsável por implantar, em 2004, este Projeto junto às três equipes de Saúde da Família da UBS-Humaitá, região central do município de São Paulo.

Ao integrar o grupo de multiplicadores desse Projeto, pude compreender a importância das ações de promoção da saúde, como meio de mudança do 
paradigma da atual saúde pública. Mudança essa que o modelo de trabalho que eu vivencio (PSF) deve fazer, mas, que na prática, possui suas limitações.

Por meio da minha experiência como enfermeira do Programa de Saúde da Família da UBS-Humaitá, e multiplicadora do referido Projeto, foi possível observar que apesar do Agente Comunitário de Saúde (ACS) ter entrado em contato com a teoria sobre os conceitos e ações de promoção da saúde durante a capacitação para o Projeto, na prática esse profissional não incorporou essa nova visão.

Baseado na constatação desse problema foi desenhado o objeto dessa pesquisa. 
INTRODUÇÃO 


\section{INTRODUÇÃO}

\subsection{O PSF E SUAS CONTRIBUIÇÕES PARA O TRABALHO DO ACS}

Ao refletir sobre o trabalho do Agente Comunitário de Saúde no Brasil foi possível observar que, ao longo do tempo, ocorreram modificações no direcionamento de suas ações, determinadas especialmente por questões socioculturais e econômicas das diferentes regiões do país.

Em 1978, a Organização Mundial de Saúde (OMS), na Conferência Internacional sobre os Cuidados Primários de Saúde em Alma-Ata, propõem a Atenção Primária de Saúde, "como estratégia mundial para o alcance da meta de saúde para todos no ano 2000". Surge nesse cenário, o agente comunitário de saúde, considerado "o primeiro elemento deste sistema" ${ }^{4)}$.

Em 1991, o Ministério da Saúde (MS) criou o Programa de Agentes Comunitários de Saúde (PACS) e, pela primeira vez na história no Brasil, são enfocas ações à família e não mais ao indivíduo, introduzindo também a noção de área de cobertura, ou seja, o mapeamento da população local ${ }^{(5)}$.

Institucionaliza-se, assim, o trabalho do ACS, por meio do Ministério da Saúde, tendo como modelo as experiências práticas com ACS no estado do Maranhão (em 1979) e no estado do Ceará com o Programa de Agentes de Saúde, considerado a primeira iniciativa estadual formalizada. Existem ainda registros de práticas com ACS nos estados do Paraná e Mato Grosso do Sul (5).

Inicialmente o PACS tinha como objetivo central contribuir para a redução da mortalidade infantil e materna, principalmente nas regiões Norte e Nordeste, estendendo a cobertura dos serviços de saúde para as áreas mais pobres e desvalidas. A partir da experiência acumulada pelo estado do Ceará, com o programa dos Agentes de Saúde, o MS percebeu que o agente poderia também ser peça importante para a reorganização do serviço básico de saúde municipal ${ }^{(5)}$.

No que se refere às dimensões do trabalho do agente comunitário de saúde, Nogueira (2002) discute duas linhas, a dimensão comunitarista e a universalista. $\mathrm{Na}$ primeira as ações do ACS se desenvolvem de acordo com os problemas vividos e 
referidos pelas famílias, já a dimensão universalista pretende usar a figura do ACS como um dos eixos estratégicos de reorganização dos serviços básicos de saúde do SUS. O ACS do PACS foi instruído, inicialmente, na visão comunitarista, mantendo um relacionamento estreito com o projeto Comunidade Solidária ${ }^{(6)}$.

Outra experiência, anterior à implantação nacional do PACS e envolvendo o trabalho de agentes comunitários, aconteceu na favela de Manguinhos (RJ). Um grupo de jovens ligados à Campanha da Fraternidade dessa comunidade, no ano de 1982, solicitou à UTGSF (Unidade de Treinamento e prestação de serviços da Escola de Saúde Pública) treinamento para execução de ações de saúde junto a essa população. Iniciou-se um trabalho voluntário que durou cerca de três anos. No final de 1985, com o apoio da UNICEF, formalizou-se o trabalho desses agentes, em regime de quarenta horas semanais e com remuneração. A comunidade, intermediada pelo ACS, passou a participar do levantamento das suas necessidades de saúde ${ }^{(7)}$.

No PACS há trinta ACS, para cada enfermeiro, este atua como instrutorsupervisor, tendo também o papel de capacitar o grupo de ACS, de acordo com as necessidades identificadas na comunidade. É importante citar que o trabalho do ACS, neste Programa, é voltado exclusivamente para as ações de prevenção e promoção da Saúde ${ }^{(8)}$.

Segundo Silva (2002), o trabalho do ACS no início da reforma sanitária, não foi para compor o processo de redemocratização do País, e sim, para "atender as necessidades de amenizar os efeitos deletérios à saúde, gerados pelo modelo hegemônico, centrado na figura do médico e em altas tecnologias e equipamentos que elevam os custos de sua manutenção" ${ }^{(9)}$.

Na medida em que o trabalho do ACS no Brasil é analisado, torna-se possível observar que sua chegada está vinculada a um momento de desenvolvimento de estratégias para conter o caos do Setor Sanitário do País e auxiliar no processo de redemocratização.

Contudo, é importante apontar que as atribuições do seu trabalho são construídas sem uma orientação operacional muito clara, causando divergências entre suas ações práticas e a proposta do programa.

Segundo documento do MS (1991), o ACS tem as seguintes atribuições: 
[...] "Cadastrar as famílias por ele atendidas; diagnosticar suas condições de saúde e moradia; atualizar estes dados permanentes, para o Sistema de Informação da Atenção Básica (SIAB); mapear, o mais detalhadamente possível, a comunidade na qual atua; identificar as micro-áreas de risco, inclusive buscando soluções para os problemas identificados junto às autoridades locais; realizar visitas domiciliares, em função da situação de saúde da família; atuar como animador do desenvolvimento coletivo da comunidade; atuar nas áreas de educação, identificando crianças fora da escola; atuar em ações humanitárias e solidárias, na busca de alternativas para geração de empregos, em situação de seca, enchente, no combate a violência etc" $[\ldots]^{(10)}$.

Silva (2002) critica o perfil exigido na contratação do ACS em relação às suas atribuições: "saber ler e escrever, ter mais de dezoito anos e ter disponibilidade para exercer tais atividades”. Sem dúvida, constata o autor, que as atribuições destacadas anteriormente "transcendem a sua formação profissional" (9).

O acompanhamento, treinamento e orientação permanente do ACS é responsabilidade do enfermeiro ${ }^{(10)}$. Se esse profissional, de um modo geral, carregar em seu arcabouço teórico uma visão hegemônica do fazer saúde, centrado em medidas medicalizantes, esse poderá se distanciar da nova concepção de saúde proposta pela reforma sanitária, identificado pela Carta de Ottawa (1986) como: "o processo de capacitação da comunidade para atuar na melhoria de sua qualidade de vida, incluindo uma maior participação no controle deste processo" (11).

No Brasil, o Programa Saúde da Família (PSF) foi concebido pelo Ministério da Saúde em 1994, contando atualmente com 27.100 equipes implantadas, sendo considerado um fenômeno irreversível pela conotação de sua aceitação em território nacional. O total de municípios em que foi implantado o PSF é de 5.110, contando com 219.400 ACS que cobrem uma população de 109 milhões e 600 mil pessoas ${ }^{(12)}$.

Segundo o MS, o PSF é entendido como estratégia de reorganização do modelo assistencial, mediante o trabalho em equipe multiprofissional em Unidades Básicas de Saúde. A equipe é responsável por um número definido de famílias, localizadas em uma determinada área geográfica. "As equipes atuam com ações de promoção da saúde, prevenção, recuperação, reabilitação de doenças e agravos mais freqüentes, e na manutenção da saúde desta comunidade" (12). 
O ACS tem participação direta na equipe de saúde, composta por médico de família, enfermeiro e auxiliar de enfermagem, o que diferencia esse Programa do PACS ${ }^{(12)}$.

Outra pesquisa, realizada em Porto. Alegre, demonstra que a principal atividade do agente comunitário de saúde, é a visita domiciliaria, fato relatado por 2/3 dos ACS pesquisados, que afirmam ser o período da tarde o de maior freqüência para realização dessa tarefa., a segunda ação mais desenvolvida pelos ACS é a educação em saúde. Apesar da visita domiciliaria ser citada como a principal atividade do agente comunitário, a observação do trabalho do ACS demonstrou que o período da tarde, relatado acima como sendo o mais usado para as visitas domiciliarias, era ocupado empiricamente por atividades administrativas, revelando divergência entre o depoimento dos ACS e o observado pelo pesquisador ${ }^{(13)}$.

De acordo com a ótica da equipe de PSF, da comunidade e dos próprios agentes, em Porto Alegre, papel do ACS foi percebido de diferentes formas nos três universos investigados, sendo os principais deles: o de "educador em saúde", o "elo entre a equipe de saúde e a comunidade" e "vigilância em saúde das famílias" (13).

Embora constatado que um dos papeis fundamentais do ACS seja o de educador, o desenvolvimento de ações de promoção da saúde ainda é escasso. As equipes de PSF, apesar desta nova proposta do setor saúde, continuam a usar de tecnologias (saberes e práticas) do modelo anterior da atenção básica à saúde ${ }^{(1)}$.

\subsection{A REGULAMENTAÇÃO DA PRÁTICA DO ACS}

A profissão de ACS é criada pela Lei $n^{\circ} 10.507$ de 10 de julho de 2002 e pelo Decreto $n^{\circ}$ - 3.189/99, que fixam as diretrizes para o exercício profissional deste trabalhador ${ }^{(14)}$.

O DEGES, (Departamento de Gestão da Educação na Saúde), com a intenção de analisar e reinterpretar as atribuições relatadas na Portaria/GM 1886, de 18 de dezembro de 1997, reestruturou o trabalho do ACS, identificando cinco eixos que deram origem às cinco competências deste profissional ${ }^{(14)}$. 
Sendo responsável pela proposição e formulação de políticas relativas à formação e educação permanente de trabalhadores da saúde, o DEGES propôs o Perfil de Competências do Agente Comunitário de Saúde com a finalidade subsidiar as instituições formadoras ${ }^{(14)}$.

Considerando que o preparo dos profissionais deveriam se adequar às propostas do SUS, mudanças na organização da formação desses trabalhadores emergiam como um grande desafio.

Descrevem-se abaixo as cinco competências propostas pelo DEGES:

[...] "Competência 1: desenvolvimento de ações que integram as equipes de saúde e as populações adscritas; competência 2: participação do ACS juntamente com a equipe, do planejamento e avaliação das ações de saúde; competência 3: desenvolvimento de ações de promoção da saúde por meio de atividades educativas, da participação social e do trabalho intersetorial; competência 4: desenvolvimento de ações de prevenção e monitoramento de situações de risco para a população; competência 5: dirige estas ações de prevenção e monitoramento aos grupos específicos e às doenças prevalentes" $[\ldots]^{(14)}$.

Embora essas competências sejam previstas pelo MS, na prática, o ACS desenvolve ações diversas, as quais nem sempre contemplam as diretrizes oficiais, como observado em pesquisa realizada em Porto Alegre ${ }^{(11)}$.

Com a realização de uma revisão bibliográfica identificaram-se 229 trabalhos, nas bases de dados Scielo e Lilacs, sobre o trabalho do ACS, durante os anos de 1989 a 2007.

Na base Scielo foram encontrados 15 trabalhos por intermédio do descritor Agente Comunitário de Saúde e 57 com o descritor Programa Saúde da Família. Na base Lilacs, encontraram-se 85 trabalhos por meio dos descritores Programa Saúde da Família e Promoção da Saúde, 105 pelo descritor Agente Comunitário de Saúde e 39 pelos descritores: Agente Comunitário de Saúde e Promoção da Saúde.

A leitura integral dos resumos projetou uma seleção de 52 trabalhos que se aproximavam do objeto de pesquisa, retirando-se os textos repetidos.

Nos textos lidos, o grupo temático de maior destaque foi o da análise do papel do ACS, entre os quais foram apontados os de busca ativa de agravos à saúde; aplicação de instrumentos com o propósito de melhorar os indicadores de saúde; 
relação com os usuários; percepção das ações do ACS por meio dos enfermeiros, médicos e famílias cadastradas. Os textos abordavam, em sua maioria, o papel desse profissional de transmitir informações de prevenção de doenças com o intuito de melhorar as condições de saúde. Nessas análises, somente 2 textos resgatavam ações de promoção da saúde como estratégia principal do trabalho do ACS, e mesmo assim, em um deles concluiu-se que as ações de promoção são raras entre os ACS, apontando uma visão medicalizante da saúde e um posicionamento biologicista ainda em destaque ${ }^{(15)}$.

A caracterização do trabalho do ACS foi o segundo objetivo majoritário dos textos analisados. Os textos descreveram as ações mais praticadas e suas implicações. Concluíram ainda que o ACS necessita de capacitação, com base teórico-prático no novo modelo da Atenção Básica, priorizando ações de prevenção e promoção da saúde.

Verificou-se menor interesse por parte dos pesquisadores no que se refere ao impacto do trabalho do ACS e sua equipe de PSF ou Unidade de Saúde, no caso do PACS. Esses trabalhos pretenderam medir, por meio de indicadores de saúde, a atuação dos ACS, que segundo todos os textos, desencadearam melhora mesmo em pequena proporção.

Bezerra (2005) analisa as concepções que predominam entre os ACS no que se refere ao processo de envelhecimento, onde as falas dos sujeitos (ACS) reproduzem uma visão formal do conceito de envelhecer ${ }^{(16)}$.

Conforme Noronha (2006), o uso da resiliência, como forma de desenvolver as ações de promoção da saúde pelos membros da equipe de PSF, auxilia na reorganização das práticas de assistência da atenção básica à saúde. Entretanto, essa reflexão precisa ser discutida entre todos da equipe e relacionada à sua prática cotidiana, superando a forma hegemônica, centrada na assistência médica, hospitalar e nas ações curativas ${ }^{(17)}$.

Santos (2005) pretende verificar se as competências propostas pelo Ministério da Saúde, a saber, Promoções da saúde, prevenção de doenças e monitoramento de risco ambiental e sanitário, contribuem para que os indivíduos aumentem o controle sobre suas vidas, baseado na perspectiva do empowerment. A partir dessa análise conclui que as ações do ACS, identificadas na pesquisa, são basicamente ações de 
educação em saúde, pautadas na transmissão de informações que segue o modelo higienista que pouco ou nada tem a ver com empowerment ${ }^{(18)}$.

Com o objetivo de analisar as concepções dos ACS em relação às práticas educativas e caracterizar suas ações com base na categoria práxis, Trapé (2007) explora as atividades cotidianas desses trabalhadores por meio de entrevistas individuais e técnica de grupo focal. Traça duas linhas de atividades que predominam entre os ACS estudados. A primeira é baseada na práxis criadora, que promove ação transformadora com criatividade, sem seguimento permanente de uma norma pré estabelecida. A segunda é baseada na práxis reiterativa, predominante entre os sujeitos analisados. É aquela que se volta para a educação prescritiva, reproduzindo sem reflexão um conhecimento acumulado, não há por parte do ACS a participação no processo de construção desse conhecimento ${ }^{(15)}$.

Dentre os trabalhos analisados não se verificou a presença de nenhum estudo que investigasse as concepções do ACS sobre promoção da saúde e suas ações. Contudo, presume-se que essa perspectiva poderia auxiliar na construção de uma prática moldada nos pressupostos da nova Saúde Pública.

O trabalho do enfermeiro no PSF demanda várias ações, entre as quais está a de supervisionar as práticas do ACS e também, de forma direta, capacitá-los.

Observa-se, na prática, que durante a capacitação rotineira do Agente Comunitário de Saúde não são seguidos, obrigatoriamente, os conceitos de promoção da saúde, apesar do Ministério da Saúde preconizá-los na proposta dos cinco eixos de competências do ACS. Nota-se que o profissional técnico responsável por capacitá-lo, tende para o modelo hegemônico, anterior à nova proposta (promoção da saúde) da atenção básica à saúde.

A questão norteadora desta pesquisa se baseia na constatação de que mesmo tendo sido capacitados em bases teórico-conceituais para operar na perspectiva da promoção da saúde, durante a capacitação para o projeto: "Nossas Crianças: Janelas de Oportunidade", na prática, o que se observa é que o ACS continuava a operar numa perspectiva de transmissão de informações para as famílias, perdendo a oportunidade de investir no fortalecimento familiar e na comunidade. A partir disso, foram formuladas questões que orientarão a pesquisa, as quais vão a seguir: 
1 Quais são as ações de promoção da saúde praticadas pelo ACS?

2 Quais são as concepções do ACS sobre promoção da saúde?

3 Em que entendimento de promoção da saúde se baseiam as concepções do ACS?

4 Qual a relação entre as concepções do ACS sobre promoção da saúde e sua prática cotidiana?

Abre-se, então, a oportunidade de investigar quais são as concepções do ACS frente ao proposto trabalho de promoção da saúde e se há coerência entre essas concepções e sua prática cotidiana. 
OBJETIVOS 


\section{OBJETIVOS}

O objetivo geral é descrever e analisar as ações de promoção da saúde realizadas pelo ACS e correlacioná-las aos conceitos teóricos relativos à Promoção da Saúde, com base nos cinco eixos da Carta de Ottawa.

Tendo-se como objetivos específicos:

1. Identificar e descrever as ações do ACS;

2. Analisar as ações do ACS, buscando identificar as concepções que dão suporte a essas ações. 
QUADRO TEÓRICO 


\section{QUADRO TEÓRICO}

\subsection{A PROMOÇÃO DA SAÚDE}

Segundo Terris (1992) apud Souza e Grundy (2004), a expressão "Promoção da Saúde" foi usada pela primeira vez no ano de 1945 por Henry Sigerist. Historiador e médico acreditava que sua prática envolvia quatro grandes princípios: a promoção da saúde, a prevenção de agravos à saúde, e o tratamento seguido da reabilitação (19).

Anterior ao enfoque moderno dado à promoção da saúde, Leavell \& Clark (1976), a entendiam como:

[...] "medidas para desenvolver uma saúde geral melhor, protegendo o
homem contra os agentes patológicos, sendo a educação em saúde um
elemento importante para esse objetivo. Um bom padrão de nutrição
ajustado às várias fases do desenvolvimento humano; aconselhamento e
educação adequada aos pais; educação sexual, aconselhamento pré-
nupcial; moradia adequada, recreação e condições agradáveis no lar e no
trabalho e aconselhamento para a saúde no contato médico paciente,
componentes da promoção" [...] ${ }^{(20)}$.

De acordo com Buss (2000), essa definição além de ser limitada, pois focaliza o indivíduo com projeção à família, denota ações de mudanças comportamentais, não se estendendo às doenças não transmissíveis, como por exemplo, as doenças crônicas ${ }^{(20)}$.

Formalmente, o movimento de promoção da saúde surgiu no Canadá, no ano de 1974, com a divulgação do informe Lalonde, tendo como motivação central o enfrentamento dos custos crescentes da assistência médica e o questionamento dos limites da abordagem exclusivamente médica para doenças crônicas ${ }^{(20)}$.

A Carta de Ottawa, estabelecida no ano de 1986 é o termo de referência básico e fundamental do desenvolvimento das idéias de promoção da saúde em todo o mundo definidas, segundo Buss, (2000) e Carvalho, (1996), pela primeira vez, em termos de políticas e estratégia ${ }^{(21)}$.

Na mesma proporção, para a América Latina, está a Declaração de Bogotá (1992). De acordo com este último documento, "a promoção de saúde na América 
Latina não pode estar descontextualizada da necessidade de transformação de uma realidade desigual e marcada por crises econômicas e políticas" (21).

A Carta de Ottawa propõe cinco campos centrais de ações ${ }^{(21)}$, a saber:

- a elaboração de políticas públicas saudáveis;

- a criação de ambientes favoráveis à saúde;

- o incremento do "poder técnico e políticos da comunidade" nos processos decisórios para se alcançar melhores níveis de saúde;

- o desenvolvimento de habilidades e atitudes pessoais favoráveis à saúde;

- a reorientação dos serviços.

É possível observar diferentes perspectivas para promoção da saúde nas quais, segundo Czeresnia e Freitas (2003), a saúde ganha uma conotação semelhante a elementos do desenvolvimento econômico, "atribuindo-lhe um valor de mercado, associando-se a isso a idéia de saúde como um recurso pessoal, que pode ser utilizado para se obter bons lucros". De acordo com essa perspectiva, os problemas de saúde não podem ser enfrentados e remediados pelo Estado, pois sua lógica é voltada à responsabilização individual, atribuindo às pessoas "a tarefa de promover sua saúde", usando da informação como instrumento para a mudança de comportamentos e estilos de vida. Ampliando essa visão, sem desconsiderar esta participação individual na busca por soluções dos problemas de saúde, mas a expandindo, encontra-se a outra perspectiva que, além de possibilitar o desenvolvimento das habilidades individuais e coletivas, integra-as às idéias dos diversos setores, "tais como a saúde pública, a educação em saúde e as políticas públicas" (21).

As idéias de promoção da saúde na América Latina são contextualizadas na Conferência Internacional sobre Promoção de Saúde nas Américas: Declaração de Santa Fé de Bogotá (Colômbia) no ano de 1992. Essa Conferência compreendeu a importante tarefa de incorporar às ações propostas pela Carta de Ottawa a diferente situação econômica e social dos paises em desenvolvimento, a qual, por sua vez, gera diferentes problemas de saúde ${ }^{(21)}$.

Os conceitos modernos de promoção da saúde, oriundos das Conferências da década de 80 , os quais foram iniciados e baseados no Canadá, por meio da Carta 
de Ottawa, embasaram-se na determinação multifatorial como forma de interpretação do processo saúde-doença, expandindo o aspecto biológico e a abordagem exclusivamente médica, como medidas de enfrentamento dos problemas de saúde das sociedades ${ }^{(20)}$.

Ao aproximar-se do primeiro campo de ação proposto na Carta de Ottawa, a elaboração de políticas públicas saudáveis, é possível observar que a saúde deve tornar-se prioridade entre políticos e dirigentes de todos os setores e níveis do Estado e este último deve ser responsável pelas "conseqüências das políticas sobre a saúde da população" (20).

A segunda ação refere-se à criação de ambientes favoráveis à saúde. $A$ análise deste campo deixa claro que para essa ação tornar-se possível é importante a ligação e dependência entre os diferentes setores de um Estado. Somente com o envolvimento coletivo dos diferentes setores é que os ambientes de trabalho, escola, família, ou seja, da vida social em geral, podem ser dirigidos para as mudanças que favoreçam a saúde ${ }^{(21)}$.

O acréscimo do poder técnico e político das comunidades, decidindo por maiores níveis de saúde, compreendem a terceira ação do movimento de Promoção da Saúde. Essa ação traz consigo a garantia de um aprendizado contínuo das comunidades sobre as questões de saúde que lhes afetam. As comunidades informadas sobre seus problemas de saúde, podem decidir pelo alcance de bons níveis de saúde, o que é conhecido também como empowerment comunitário ${ }^{(21) .}$

O quarto campo de ação da Promoção da Saúde tem o seu destaque na educação em saúde. A capacitação individual e coletiva é considerada para desenvolver habilidades e atitudes que favoreçam a saúde. Uma educação em saúde voltada para a reflexão sobre as idéias de saúde, nas diferentes etapas da vida e diferentes ambientes da vida social, pode ser uma importante contribuição para o empowerment individual ${ }^{(21)}$.

O quinto e último campo proposto na Carta de Ottawa, implica em um novo direcionamento dos serviços de saúde, superando assim o modelo biomédico, centrado na doença. Entende-se que a ocorrência desta superação, deva estar relacionada ao financiamento, bem como às práticas e formação dos profissionais (21). 
Segundo Buss (2000), na América Latina, que possui um diferencial econômico em relação aos paises desenvolvidos, torna-se necessário considerar as desigualdades econômicas e sociais, para então desenvolver ações de Promoção da Saúde ${ }^{(20)}$.

Para os paises da América Latina, a Declaração de Bogotá foi o marco do desenvolvimento das idéias de Promoção da Saúde. Segundo o seu primeiro princípio é necessário superar as diversas desigualdades, de ordem social, ambiental, econômica, cultural, não se esquecendo de estender quantitativamente e qualitativamente os serviços de saúde existentes ${ }^{(20)}$.

Em conseqüência desta diferenciação sócio-econômica dos países da América Latina, a segunda ação de Promoção da Saúde diz respeito aos programas de saúde pública, que devem equilibrar as atividades voltadas ao combate de doenças causadas pela pobreza e atraso com aquelas decorrentes da vida social urbanizada e industrializada ${ }^{(20)}$.

A terceira ação proposta na declaração de Bogotá, reenfoca as dimensões do sistema democrático na sociedade. O Estado deve ser governado pelo povo e o poder ser distribuído equitativamente. A equidade é conquistada, identificando os fatores que desencadeiam a iniqüidade, juntamente com propostas para amenizar seus efeitos, atuando na transformação dos dirigentes e da população ${ }^{(20)}$.

Como proposta final da declaração de Bogotá está o desenvolvimento das pessoas e da sociedade de forma integral, evitando sua dicotomização.

Ao observar as idéias de Promoção da Saúde adaptadas aos paises da América Latina, nota-se como núcleo norteador o equilíbrio entre os interesses econômicos e as propostas sociais decorrentes de seus problemas de saúde, colaborando para o desenvolvimento da solidariedade e equidade ${ }^{(20)}$.

As idéias da Promoção da Saúde estão presentes no campo da Saúde Coletiva, tornando assim, imprescindível uma breve explanação sobre sua conceituação e suas formas de expressão.

Pensar saúde de forma ampliada, considerando os determinantes econômicos da doença e do sistema de saúde, leva estudiosos do Brasil e de países da América Latina a refletirem sobre o modelo biomédico usado para resolver as questões de saúde da população ${ }^{(22)}$. 
Em 27 de setembro de 1979, o campo da Saúde Coletiva é institucionalizado no plano nacional por meio da criação da ABRASCO. Em 1982 publicam-se seus princípios básicos:

[...] "aprimoramento do ensino e da pesquisa, intensificação do intercâmbio entre as instituições, obtenção de apoio financeiro e técnico, cooperação entre instituições de ensino, valorização dos programas de ensino, promoção e disseminação dos conhecimentos da saúde coletiva. Não se trata de uma perspectiva exclusiva de assuntos referentes ao ensino, mas de participação efetiva na definição e implementação de uma política de recursos humanos em saúde coletiva, associada a uma análise das condições de saúde da população e de incentivo à pesquisa. Assume uma posição política e técnica, ou seja, a necessidade de reformulação do setor saúde e a concepção da saúde como um direito do cidadão e dever do Estado" [...] ${ }^{(22)}$.

É possível dividir o campo da Saúde Coletiva em três grandes disciplinas: "as ciências sociais e humanas, a epidemiologia e a política e o planejamento" (22).

O fortalecimento deste movimento se dá por sua atuação tanto nas questões políticas da assistência à saúde, como também nos Cursos de graduação, especialização, residência, pós-graduação, nos Congressos, onde são evidenciados trabalhos científicos que comprovam sua "extensão, profundidade e vitalidade" e nas Publicações em revistas especializadas na temática ${ }^{(22)}$.

Cria-se então um verdadeiro movimento sanitário, em que o curso dos debates recriados em novos moldes (Saúde Coletiva) dá vazão a Reforma Sanitária no Brasil.

Com a Reforma Sanitária cria-se o SUS, Sistema Único de Saúde, um "arranjo organizacional do Estado brasileiro que dá suporte as efetivações da política de saúde no Brasil e traduz em ações os princípios e diretrizes desta política" (23).

Em setembro de 2005 foi definida a Agenda de Compromisso pela Saúde. Um de seus eixos agrega o Pacto pela Vida, apresentado como: Política Nacional de Promoção da Saúde (PNPS) ${ }^{(24)}$.

Seu objetivo geral é:

[...] "Promover a qualidade de vida e reduzir vulnerabilidade e riscos à saúde relacionados aos seus determinantes e condicionantes - modos de viver, condições de trabalho, habitação, ambiente, educação, lazer, cultura, acesso a bens e serviços essenciais." [...] ${ }^{(24)}$.

Os objetivos específicos da Política Nacional de Promoção da Saúde voltamse para a implantação/implementação das ações de promoção da saúde na Atenção 
Básica e para a ampliação da autonomia dos indivíduos e coletividades no que se refere ao cuidado integral de sua saúde, diminuindo assim as "desigualdades de toda e qualquer ordem" ${ }^{(24)}$.

Foram priorizadas as ações voltadas a:

[...] "Divulgação e implementação da PNPS, Alimentação Saudável, Prática corporal/atividade física, Prevenção e controle do tabagismo, Redução da morbimortalidade em decorrência do uso abusivo de álcool e outras drogas, Redução da morbimortalidade por acidentes de trânsito, Prevenção da violência e estímulo à cultura de paz e Promoção de desenvolvimento sustentável" [...] ${ }^{(24)}$.

Tem-se, a partir deste momento, uma pactuação entre as três esferas políticas: municipal, estadual e federal no que se refere à promoção da saúde, traçando suas vias, objetivos, diretrizes, estratégias de implementação e ações específicas de promoção da saúde, principalmente no campo da Atenção Básica (24).

O conjunto de ações de Promoção da Saúde envolve a capacitação dos indivíduos e coletividades, para o desenvolvimento de sua autonomia e participação política, com o objetivo de melhorar a qualidade de vida e saúde ${ }^{(25)}$.

A prática do ACS que apreende essas ações de promoção da saúde pode facilitar os acessos à participação social, objetivando o desenvolvimento de políticas de saúde mais justas, necessárias e eficientes. 
METODOLOGIA 


\section{METODOLOGIA}

Esta pesquisa compreende um estudo de caso do tipo descritivo, que pretende fazer uma abordagem quanti-qualitativa das ações de promoção da saúde do ACS e correlacioná-las aos conceitos de Promoção da Saúde, com base nos cinco eixos da Carta de Ottawa, considerando o método do materialismo histórico e dialético. Tal método acredita no papel do homem como transformador e não apenas como receptor das influências sociais. Segundo Marx apud Fonseca (2004), as idéias submetidas à prática é que transformam o mundo e não somente as idéias ${ }^{(26)}$.

De acordo com Marx apud Fonseca (2004), o trabalho é responsável pelo surgimento da organização social, diferenciando o homem, que trabalha por meio da consciência, do animal, que trabalha movimentado pelo instinto ${ }^{(26)}$.

Este estudo se desenvolve, portanto, respaldado por esse método de pesquisa, que vê as idéias submetidas à prática (consciência/conhecimento).

A estratégia operacional desta pesquisa está baseada na pesquisa CIPESC (2000) ${ }^{(27)}$ e, o instrumento para coletar os dados quantitativos foi baseado na pesquisa de Santos (2005), em que, primeiramente, aplica-se um questionário para caracterização do perfil do ACS e, posteriormente, um Formulário de Atividades (ANEXO-I) do ACS, construído de acordo com as cinco competências propostas pelo Ministério da Saúde, por meio do DEGES ${ }^{(18)}$.

Os dados são organizados e apresentados sob a forma de gráficos e analisados conforme a freqüência de suas respostas, observando-se as ações de Promoção da Saúde, Prevenção e monitoramento de risco ambiental e sanitário e de prevenção e monitoramento a grupos específicos e morbidades, ações estas consideradas por esta pesquisa como ações de promoção da saúde.

O Grupo Focal teve como objetivo acrescentar qualidade ao dado quantitativo. Desta forma, foram selecionados e apresentados alguns gráficos, sobre as ações de promoção da saúde e de prevenção e monitoramento dos riscos ambientais e sanitários mais frequentemente realizados pelos ACS pesquisados. A partir desses dados iniciava-se a discussão entre os ACS participantes desta investigação, sobre 
suas concepções de promoção da saúde e como entendiam que essas deveriam ser colocadas em prática.

\subsection{CENÁRIO DO ESTUDO}

O cenário de estudo desta pesquisa foi a UBS Humaitá - Dr. João de Azevedo Lage, localizada no bairro da Bela Vista, região Central do município de São Paulo, pertencente à Coordenadoria Regional de Saúde Centro-Oeste. A Figura (1) nos mostra a localização das Coordenadorias Regionais de Saúde do Município de São Paulo

Esta UBS é considerada de atuação mista, pois contempla dois modelos de assistência básica à saúde: o tradicional, que conta com atendimento médico clínico, pediátrico e ginecológico e a Estratégia Saúde da Família, com três equipes montadas, contendo um médico generalista, um enfermeiro, dois auxiliares de enfermagem e seis agentes comunitários de saúde cada uma.

Cada uma das três equipes de PSF possui em média 930 famílias e, aproximadamente 2.675 pessoas, somando um total geral entre todas as equipes de 2.792 famílias e 8.023 pessoas. Na área adscrita da UBS Humaitá estão computadas um total de 73.000 pessoas, mais os trabalhadores da região, que também podem ser atendidos. É importante considerar que as três equipes de PSF, cobrem em média, 30\% da área adscrita da UBS em questão ${ }^{(28)}$. 
COORDENADORIA REGIONAL DE SAÚDE E SUPERVISÃo TÉCNICA DE SAÚDE MUNICIPIO DE SÃo PAULO

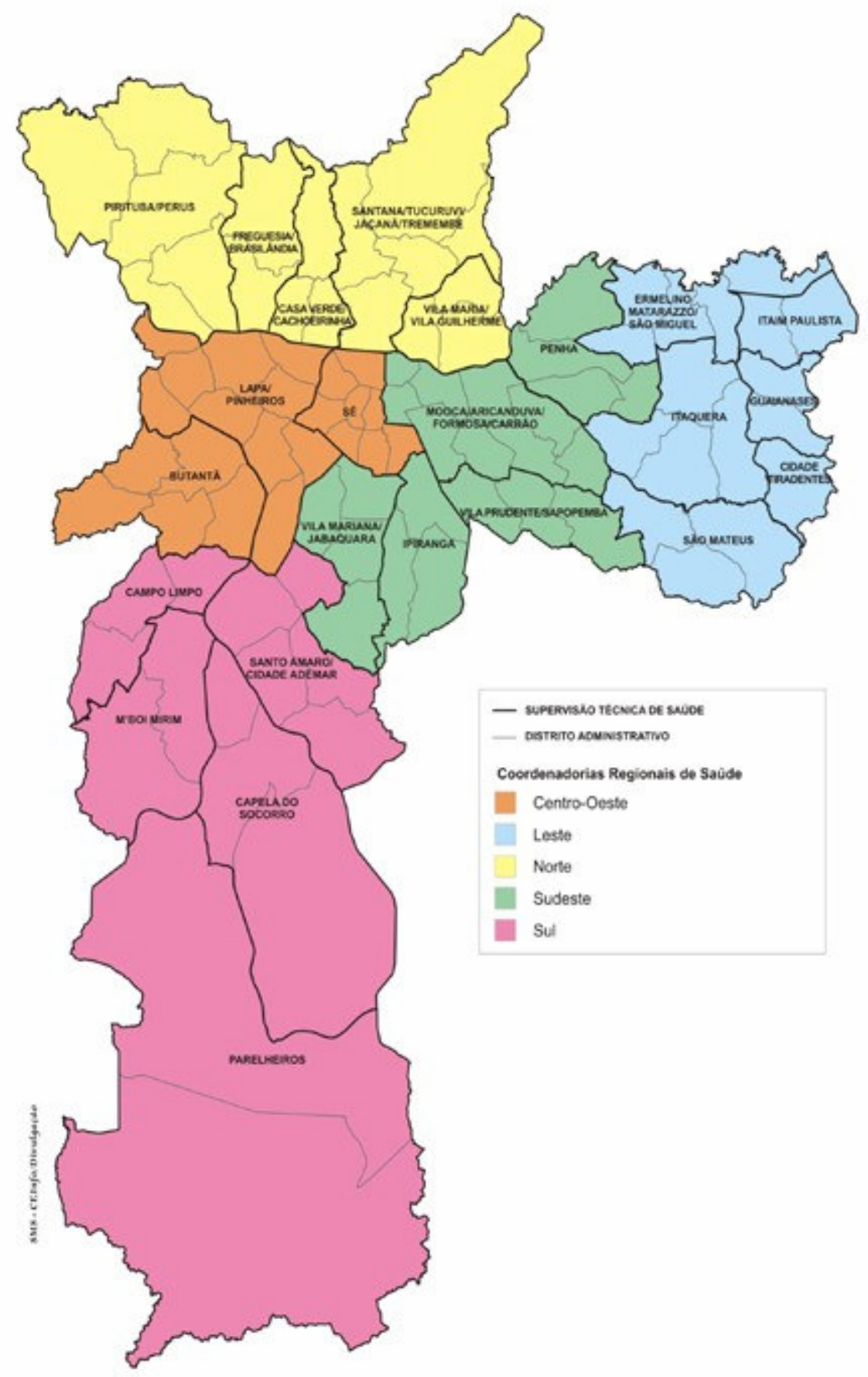

Figura 1 - Mapa das coordenadorias regionais do município de São Paulo-2007

Fonte: SMS. CEInfo Divulgação

A região Centro-Oeste conta com uma população de 1.231.249 habitantes, com uma taxa anual de crescimento da população de $-1,2 \%$. O índice de crianças menores de dez anos nessa população é de $11,3 \%$, o de adolescente é de $11,9 \%$, já 
o de idosos é de 16\%. A taxa bruta de natalidade (por 1000 hab.) é de 15,9 e a de mortalidade (por 1000 hab.) é de 7,8. $O$ índice de população que não possui plano ou convênio de saúde é de $39,2 \%{ }^{(29)}$.

Os dados sócio-econômicos indicam 99,0\% de cômodos abastecidos de água em rede, $96,7 \%$ de coletas de esgoto em rede, $97,4 \%$ de lixo coletado, $43,8 \%$ dos chefes de família com 12 anos ou mais de estudo e 21,5\% da população com renda familiar abaixo de $\mathrm{R} \$ 400,00^{(29)}$.

Os dados de mortalidade mostram que a primeira causa de morte ocorre por Doenças Isquêmicas do coração, a segunda se dá por Doenças Cérebro-Vasculares e a terceira, por Pneumonia ${ }^{(29)}$.

Em relação aos dados de nascidos vivos observamos que $74,0 \%$ dos prénatais são quantitativamente adequados (sete e mais consultas), 9,2\% dos recém nascidos com baixo peso ao nascer, $58 \%$ de partos cesarianas e $10,2 \%$ de mães adolescentes (menores de 20 anos) ${ }^{(29)}$.

De acordo com os dados de estrutura de Serviços, a região Centro-Oeste conta com 19 hospitais que atendem pelo SUS (incluindo os públicos), 31 UBS, 21 Unidades Especializadas Municipais. O Programa Saúde da Família possui uma cobertura de $11,1 \%$ da população e o PACS corresponde a $4 \%{ }^{(29)}$.

A porcentagem de Unidades de Saúde com Conselho Gestor constituído representa 83,9\%, apontando aderência maioral das unidades desta região em relação às demais regiões do município ${ }^{(29)}$.

De acordo com a Base de Equipamentos da Secretaria Municipal de Assistência e Desenvolvimento Social (SMADS) de fevereiro a outubro de 2006, as instituições sociais presentes na região da UBS Humaitá- Dr. João de Azevedo Lage são ${ }^{(30)}$ :

- Dois Núcleos Sócio-Educacionais para crianças e adolescentes.

- Uma Casa de Acolhida/Passagem para crianças e jovens

- Um Abrigo para Adultos sob Cuidados Especiais

- Um Núcleo de Defesa e Convivência da Mulher

- Um projeto FUMCAD- Proteção Básica

- Quatro Albergues

- Três Moradias Provisórias

- Dois Núcleos de Atendimento e Trabalho sócio-educativo com Famílias. 
- Um Núcleo de Serviços de Convivência para População em Situação de Rua

De acordo com documento adquirido no estabelecimento da Unidade Básica Humaitá- Dr. João de Azevedo Lage, as instituições de ensino público da região são: duas EMEF (Escola Municipais de Ensino Fundamental), duas EMEI (Escola Municipal de Ensino Infantil), duas EEEF (Escola Estadual de Ensino Fundamental), duas EEEM (Escola Estaduais de Ensino Médio) e oito creches municipais ${ }^{(31)}$.

Considerando o índice de exclusão/inclusão social nos bairros da Bela Vista e Liberdade, área de abrangência da UBS-Humaitá, encontram-se,, segundo pesquisa de Aldaíza Sposati, os seguintes dados: no primeiro bairro citado, o índice de exclusão/inclusão é de 0,30 à 0,60 e no segundo, de $-0,30$ a $-0,01$. É possível interpretar que no bairro da Bela Vista existe um baixo índice de inclusão social e, na Liberdade, um baixo índice de exclusão social, de acordo com a autora ${ }^{(32)}$.

\subsection{SUJEITO DA PESQUISA}

Foram sujeitos dessa pesquisa dezesseis (16) ACS da UBS-Humaitá. O critério para seleção dos sujeitos consistiu na aceitação voluntária em participar da pesquisa. Durante o grupo focal participaram dez (10) ACS, compondo um número mínimo para o desenvolvimento do método qualitativo.

\subsection{PROCEDIMENTO ÉTICO LEGAL}

O presente projeto passou por avaliação do Comitê de Ética em Pesquisa da Prefeitura do município de São Paulo, tendo o parecer de aprovação de № 0088/07CEP/SMS CAAE № 0028/07. Após, iniciou-se a coleta de dados em campo onde, através do termo de consentimento, os Agentes Comunitários de Saúde receberam todas as orientações, tiraram suas dúvidas e por livre e espontânea vontade, participaram da pesquisa, sem que isso acarretasse nenhum tipo de prejuízo ao mesmo. 
O termo de consentimento livre e esclarecido (Anexo-II) foi feito em duas via. Com linguagem acessível, conteve: justificativa, objetivos, procedimentos, riscos possíveis e benefícios esperados e garantia de esclarecimentos antes e durante a pesquisa, sem prejuízo ou constrangimento, garantia de sigilo assegurando a privacidade dos sujeitos, confiabilidade dos dados, nome do pesquisador responsável e contato.

\subsection{ANÁLISE DOS DADOS}

O Discurso do Sujeito Coletivo (DSC) é uma metodologia que prepara a matéria prima dos depoimentos para revelar o que pensam as coletividades e sobre este material preparado, procurar dar explicação do porque pensam assim as coletividades pesquisadas ${ }^{(34)}$.

Após a transcrição das falas do grupo focal, foi realizada a análise, que seguiu as seguintes etapas ${ }^{(35)}$ :

Primeira Etapa - Após a transcrição literal das falas, foram resgatadas as representações do indivíduo para cada questão proposta, descrevendo as idéias centrais e respectivas expressões-chave ${ }^{(35)}$.

Segunda Etapa - Nesta etapa foram listadas todas as idéias centrais com suas respectivas expressões-chave.

Terceira Etapa - A listagem das Expressões Chaves foi transformada em um discurso, como se houvesse apenas um indivíduo falando, sendo portador de um discurso-síntese de todos os componentes do sujeito coletivo.

Para a análise dos discursos foram empregadas três figuras metodológicas: a Idéia Central; as Expressões-Chave e o Discurso do Sujeito Coletivo.

Segundo os criadores desta metodologia (Simioni e col 1997; Lefévre e Lefévre, 1998; Lefévre e col 2000; Lefévre, 2003), a Idéia Central pode ser entendida como a síntese do conteúdo discursivo explicitado pelos sujeitos, estando presente nas afirmações, negações e nos juízos de valor a respeito da realidade institucional bem como do contexto social no qual os sujeitos estão envolvidos ${ }^{\left({ }^{(3)}\right)}$. 
Os trechos selecionados dos discursos que servem para ilustrar as Idéias Centrais são definidos como Expressões-Chave. A literalidade das falas deve ser aqui resgatada, sendo as mesmas consideradas uma espécie de "prova-discursivaempírica" da "verdade" das Idéias Centrais.

O DSC é uma estratégia metodológica que objetiva tornar mais claro o pensamento de uma dada representação social. É uma forma discursiva de apresentação e de tratamento dos depoimentos que compõem o substrato de uma representação social. Em síntese, O DSC é como se o discurso de todos fosse o discurso de um só ${ }^{(34)}$.

\subsection{PROCEDIMENTOS E INSTRUMENTOS PARA A COLETA DE DADOS}

$O$ instrumento para a coleta de dados quantitativos foi baseado na pesquisa de Santos (2005), com a aplicação de um questionário para a caracterização do ACS e em seguida "um formulário de atividades (Anexo-I) que busca identificar as ações que este profissional realiza, bem como a freqüência com a qual executa tais ações" (18).

As informações foram processadas em um banco de dados no programa computacional EXCEL e organizadas sob a forma de gráficos. A seguir, com base na análise da freqüência dos dados, selecionaram-se alguns gráficos para orientar a discussão do grupo focal.

O interesse pela técnica do grupo focal, bastante utilizado nas áreas de Mercadologia e Educação em Saúde, vem crescendo no campo de investigação da Enfermagem. Segundo Dall'Agnol e Trench (1999), os diferentes pontos de vista dos sujeitos presentes, auxiliam na elaboração de certas percepções de um fenômeno. A passagem da fase dessas percepções adquiridas para a elaboração-expressão ocorre no processo de interação de um grupo ${ }^{(33)}$.

Para uma melhor compreensão da técnica de Grupo Focal, é necessário, primeiramente, realizar a conceituação de grupo. A abordagem que se dá a um grupo pode manifestar-se por meio de duas vertentes principais. Uma pautada na concepção linear-tradicional e outra na perspectiva dialética ${ }^{(33)}$. 
A primeira tem o intuito de conduzir os participantes, evitando assim situações conflitantes, geralmente os sentimentos são reprimidos. Refere-se neste caso ao Grupo Objeto, onde estão presentes as modalidades de "serialidade, indivíduos justaposto sob uma capa de coerência e, de tarefismo que, segue o estilo taylorista de organização de trabalho, onde, cada um tem o seu lugar" $\left.{ }^{(33}\right)$.

Já a perspectiva dialética de abordagem de grupo, de acordo com Dall'Agnol e Trench (1999), elegeu o Grupo Operativo de Pichon-Revière (1991, p. 177) apud Dall'Agnol e Trench (1999) que define grupo como "um conjunto de pessoas ligadas entre si por constantes de tempo e espaço e articuladas por sua mútua representação interna, que propõe explícita e implicitamente uma tarefa, o que constitui sua finalidade" ${ }^{(33)}$

O grupo focal desta pesquisa foi conduzido e possui características que se aproximam dessa segunda abordagem. As "falas" do grupo focal foram registradas por áudio e escrita, preservando os comportamentos sinalizados que não foram verbalizados.

Os discursos colhidos no grupo focal foram analisados por meio do método de análise do Discurso do Sujeito Coletivo (DSC) ${ }^{(34)}$. 
RESULTADOS E DISCUSSÃO 


\section{RESULTADOS E DISCUSSÃO}

\subsection{O ACS NA UNIDADE BÁSICA DE SAÚDE: UMA BREVE CARACTERIZAÇÃO}

Apresenta-se aqui a caracterização dos ACS entrevistados bem como o tipo e a freqüência de suas competências, seguindo-se os mesmos passos de uma análise descritiva.

Com relação ao sexo, é possível observar que 100\% (16) dos ACS entrevistados são do sexo feminino e por este fator, considerar-se-á, nas próximas análises, a questão de gênero. Com relação a faixa etária, o gráfico um demonstra que dez (10) ACS, (62\%), estão entre quarenta e cinqüenta e nove anos de idade e seis (6) (38\%) entre vinte e trinta e nove anos de idade.

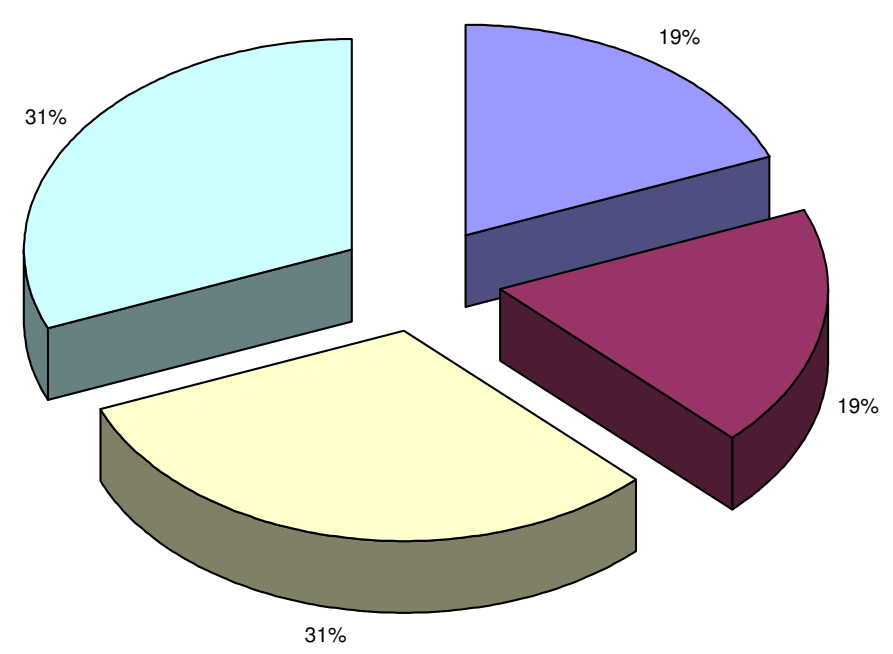

$\square 20$ a 29 anos $\square 30$ a 39 anos $\square 40$ a 49 anos $\square 50$ a 59 anos

\section{Gráfico 1 - Faixa etária dos sujeitos desta pesquisa (ACS).}

Com relação à cor, verificou-se que a parda encontra-se em destaque, com sete (7) dos ACS inclusos (44\%), seguido de cinco (5) brancos (31\%) e de quatro (4) pretos (25\%). Observa-se que os brancos estão em menor número e que os pardos compreendem quase metade do total dos ACS. 
Em termos de região de nascimento, quinze (15) dos ACS entrevistados (94\%) nasceram na região sudeste e somente $6 \%$, ou seja, um único componente deste grupo nasceu na região nordeste. Diante dessa informação, acredita-se que a maioria dos ACS provém de uma mesma cultura regional, o que poderia ou não facilitar no enfrentamento de situações culturais diferentes entre seus cadastrados.

Em relação à origem do ACS, quatorze (14) são nascidos na zona urbana (87\%) em comparação com doze (12), nascidos em zona rural (13\%). Essa baixa porcentagem de originários rurais revela uma pequena taxa de migração do campo para os centros urbanos por parte destes profissionais.

No que se refere ao estado civil, sete (7) dos ACS são solteiros (47\%), desta forma é possível supor que esses ACS, todos do sexo feminino, não possuam companheiros para dividir as despesas e atividades da casa, acumulando várias funções, inclusive a de mantenedores (as) do lar. Seis (6) são unidos (40\%) e dois (2) são separados (13\%). $60 \%$ do grupo investigado, nove (9) ACS declaram viver sozinho, ou melhor, sem companheiro.

O gráfico a seguir refere-se a escolaridade dos sujeitos.

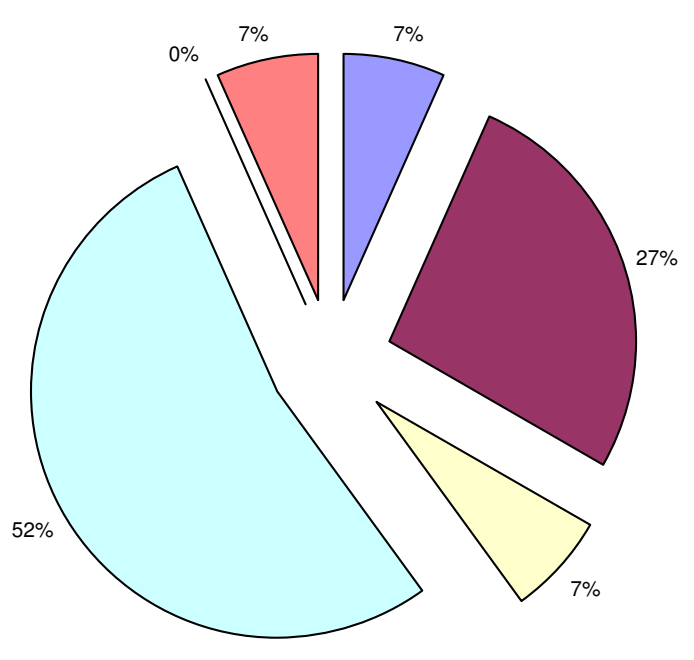

$\square 1^{\circ}$ grau Incompleto

Gráfico 2 - Escolaridade dos sujeitos desta pesquisa (ACS). 
A escolaridade é um índice usado para medir o nível de desenvolvimento pessoal de uma determinada população, isto mostra que, quanto maior for a escolaridade, maior a chance de ocorrer este desenvolvimento. No gráfico acima oito (8) ACS entrevistados concluíram o ensino médio (52\%), Quatro (4), o ensino fundamental (27\%), 7\% (Um ACS) possui ensino médio incompleto, 7\% (Um ACS) não concluiu o ensino fundamental e $7 \%$, ou seja, um ACS possui ensino superior completo. Um ACS não se manifestou sobre essa freqüência. A ocorrência da escolaridade média representada por mais da metade dos ACS, auxiliará na compreensão das dificuldades de interpretação sobre as ações descritas no formulário ${ }^{(32)}$.

Quase dois terços dos ACS, onze (11), relataram que não realizaram curso profissionalizante (69\%) e cinco (5) relataram que o fizeram (39\%). A tabela abaixo aponta os cursos profissionalizantes realizados pelos entrevistados: 
Tabela -1 Descrição do curso profissionalizante realizado por ACS e sua distribuição.

\begin{tabular}{lc}
\hline Curso profissionalizante & № \\
\hline $\begin{array}{l}\text { Auxiliar de enfermagem } \\
\text { Técnico de enfermagem e auxiliar de }\end{array}$ & 1 \\
$\begin{array}{l}\text { enfermagem } \\
\text { Vigilante }\end{array}$ & 1 \\
\begin{tabular}{ll} 
Informática, Recursos humanos, & 1 \\
contabilidade, administração e corretor & \\
\hline
\end{tabular}
\end{tabular}

A maior parte dos cursos vincula-se à área da saúde, sendo que $60 \%$ dos cursos profissionalizantes relatados referem-se a auxiliar de enfermagem, dois (2) ACS e um (1) técnico de enfermagem e os demais $40 \%$, a cursos de vigilante, um (1) ACS, informática, um (1) ACS, recursos humanos, um (1) ACS, contabilidade, um (1) ACS, administração, um (1) ACS e corretor, um (1) ACS.

Com relação ao número de filhos, verificou-se que sete (7) dos ACS pesquisados possuem dois filhos (43\%), cinco (5) um filho (31\%), dois (2) não possuem filhos (13\%) e dois (2) três filhos (13\%). É possível constatar, portanto, que o tamanho das famílias dos ACS entrevistados, distribui-se entre famílias medianas a pequenas. Com exceção de uma parcela diminuída de $13 \%$, ou seja, dois casos relatados com três filhos.

Com relação à renda, o gráfico 3 permite uma comparação com os dados anteriormente discutidos. 


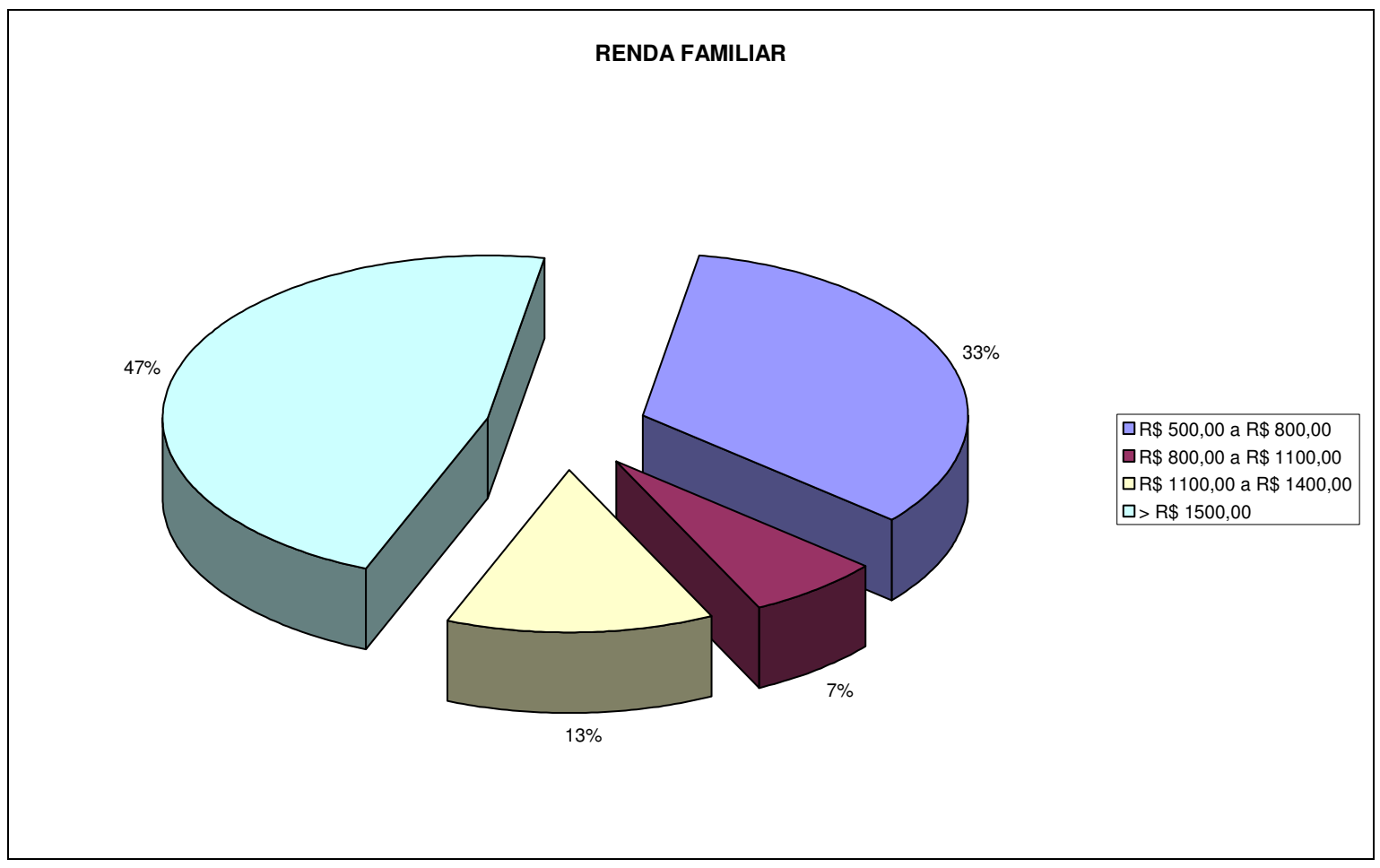

Gráfico 3 - Renda familiar do sujeito desta pesquisa (ACS).

Ao fazer-se essa comparação, nota-se uma disposição similar entre seus índices. O índice referente a dois filhos (43\%), que representa sete (7) ACS equiparase com o da renda familiar acima de $R \$ 1500,00$ (47\%), que representa sete (7) ACS. Da mesma forma quando se compara que cinco (5) ACS (31\%) com um único filho com cinco (5) ACS (33\%) com renda entre $R \$ 500,00$ e $R \$ 800,00$. Seguindo esta mesma lógica tem-se dois (2) ACS (13\%) com três filhos e dois (2) ACS (13\%) vivendo com uma renda familiar entre $R \$ 1100,00$ a $R \$ 1400,00$. E por fim, os profissionais sem filhos que somam 13\% do total, ou seja, dois (2) ACS se relacionam com a renda familiar entre $R \$ 800,00$ a $R \$ 1100,00$, um (1) ACS (7\% do total dos profissionais investigados). 


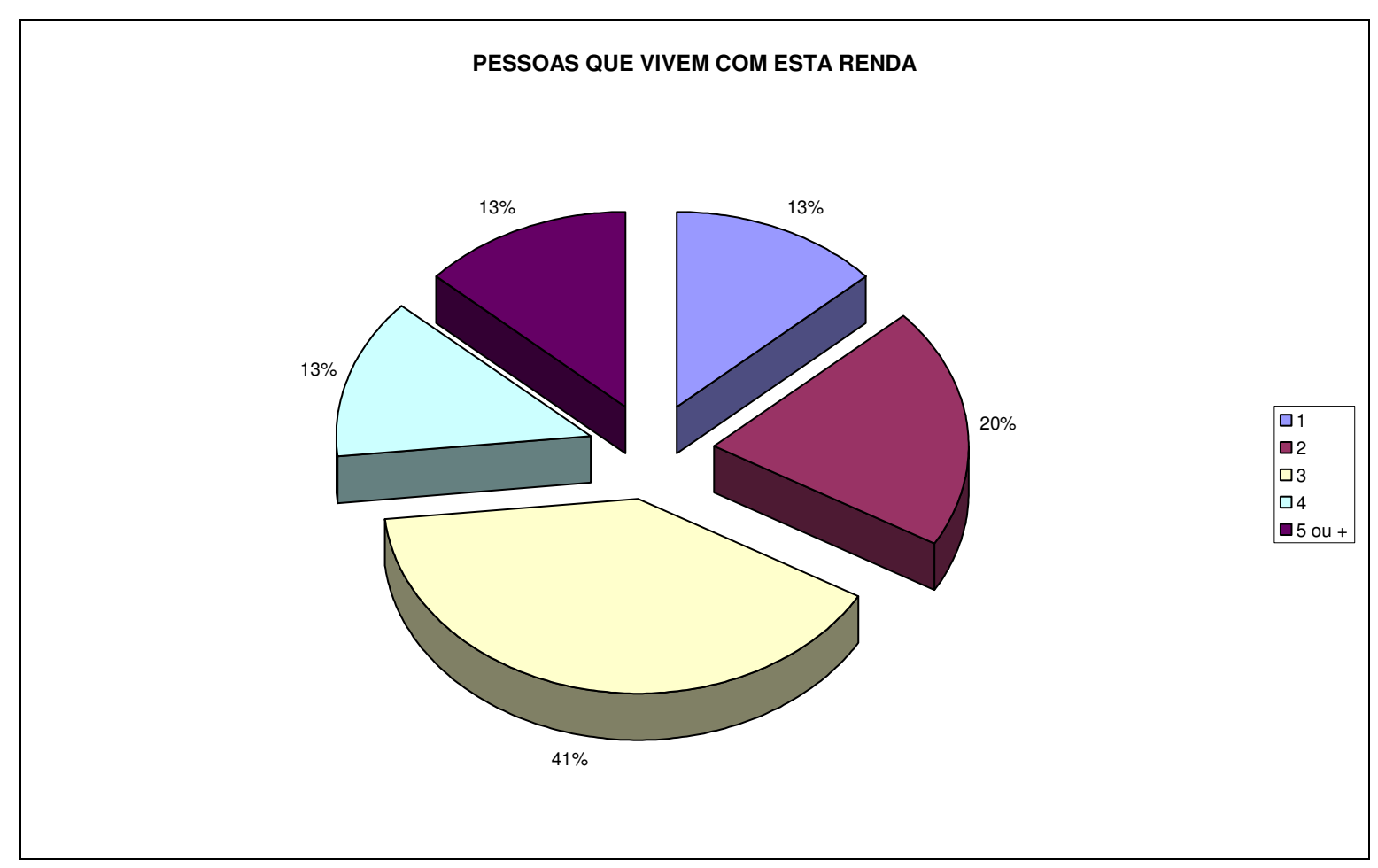

Gráfico 4 - Pessoas que vivem com a renda familiar do ACS.

O gráfico acima indica quantas pessoas, incluindo o próprio ACS, vivem com o rendimento familiar. O resultado da pesquisa mostrou que para seis (6) ACS, três (3) pessoas vivem com esta renda (41\%), para três (3) ACS, duas pessoas vivem com esta renda (20\%), para um (1) ACS, apenas uma pessoa vive com esta renda (13\%), para um (1) ACS outras quatro pessoas vivem com esta renda (13\%) e ainda para um (1) ACS, cinco ou mais pessoas vivem com este rendimento (13\%).

Esse gráfico permitiu observar que apenas $26 \%$, ou seja, quatro (4) ACS possuem famílias com quatro, cinco ou mais pessoas, apontando planejamento familiar entre a maioria dos ACS, característica importante para quem lida com os vários aspectos da saúde familiar.

Com relação à moradia, cinco (5) ACS (31\%) indicaram possuir casa própria, dez (10) encontram-se em moradias alugadas (63\%) e $6 \%$, ou seja, um ACS relata viver em moradia cedida.

Sabe-se que o valor do aluguel na região da Bela Vista, por tratar-se de uma região central e por contar com vários benefícios como escolas, creches, hospitais, postos de saúde e oferta de emprego, ultrapassa geralmente o valor do salário mínimo. Considerando que o ACS receba por volta de dois salários mínimos, 
supõem-se, então, que dez (10) ACS (63\%) consumam em média $50 \%$ do seu rendimento com a moradia alugada, limitando os demais tipos de consumo como alimentação, escola, transporte, laser e etc, aos $50 \%$ restantes.

Com relação ao tempo de moradia no bairro, dez (10) ACS entrevistados, (63\%), disseram morar há mais de quinze anos, quatro (4) entre onze e quinze anos, (25\%), um (1) entre seis a dez anos, (6\%), e um (1) entre dois e cinco anos, (6\%). Esses dados confirmam que, durante a seleção de ACS desta UBS, o quesito tempo mínimo de dois anos de moradia no bairro foi preservado, 100\%, ou seja, dezesseis (16) ACS investigados relatam serem moradores do bairro onde trabalham. Tal quesito é condição primordial para manter uma das características fundamentais desse tipo de trabalho: a proximidade aos valores e hábitos da comunidade.

Quando questionados sobre a ocupação que possuíam antes de se tornarem ACS, o rol de respostas apresentadas foram: Do lar (2), babá (1), auxiliar de escritório (2), atividade religiosa (1), trabalho em escola(1), costureira (1), secretária(2), auxiliar administrativo (1), vendedora (1), oficial da câmara da justiça (1), doméstica (1), auxiliar do desenvolvimento infantil (1), auxiliar de cozinha (1), auxiliar de serviços gerais (1) e professor (1).

Entre as dezesseis diferentes ocupações exercidas pelos ACS, lembrando o fato de que alguns declararam ter realizado mais do que uma ocupação, destaca-se a área administrativa com um índice de $31,2 \%$, ou seja, cinco (5) referências, em seguida, 12,5\% para Do lar, 18,7\% para ocupações voltadas ao cuidado com crianças, 6,2\% para Doméstica, 6,2\% para professor, 6,2\% para auxiliar de serviços gerais, $6,2 \%$ para auxiliar de cozinha e $6,2 \%$ para a ocupação relacionada com a holística, acreditando ser essa última manifestação de âmbito religioso. Nota-se que o ACS, de maneira geral, esteve presente no mercado de trabalho com funções pouco relacionadas à sua profissão atual.

Com relação a sua inserção formal no mercado de trabalho, 87\%, quatorze (14) ACS, referiram possuir carteira de trabalho assinada nas ocupações anteriores e apenas dois (2) negam esta ocorrência (13\%). Com isso, entende-se que o trabalho formal é uma prática comum entre a maioria dos entrevistados, o que os tornam familiarizados às metas de produtividade e responsabilidade inerentes ao trabalho formal. 
A maioria dos entrevistados, quinze (15) ACS preferem não realizar outra atividade remunerada concomitante (94\%), já que o tempo oferecido ao trabalho de Agente Comunitário de Saúde é integral, ou seja, quarenta horas semanais. Apenas $6 \%$ dos ACSs, numericamente traduzido para um único profissional, possui outra atividade remunerada.

Quanto à motivação inicial em ser um ACS, dez (10) ACSs, (62\%), viram nessa função uma oportunidade de um emprego, dado que superou todas as demais alternativas. A área de saúde e a apreciação por trabalhar com pessoas, também demonstram destaque, $13 \%$ de cada motivo citado, ou seja, dois (2) ACS para a primeira e dois para a segunda citação. Restaram os motivos em colaborar com a comunidade, com $6 \%$, um (1) ACS e outros motivos, igualmente com $6 \%$. A opção "Conhecia o trabalho", não obteve nenhuma indicação, apontando que este trabalho não trouxe aos atuais ACS referências profissionais anteriores.

Ao perguntar se o entrevistado gosta de trabalhar como ACS, obteve-se $100 \%$ das respostas afirmativas, apontando, sem indicar profundidade, que o profissional, de maneira geral, está satisfeito com seu trabalho.

O gráfico demonstra que $50 \%$ dos ACS pesquisados, oito (8), trabalham no Programa Saúde da Família num período entre quatro e seis anos, 25\% destes profissionais, quatro (4) ACS, entre um e dois anos e igualmente a esse, trabalham a menos de seis meses. O tempo de trabalho é um importante dado para compreender dificuldades enfrentadas por alguns ACS no preenchimento do Formulário de atividades (ANEXO-I) que, serão descritas adiante, de forma mais detalhada.

É importante lembrar que o treinamento para execução das funções de Agente Comunitário de Saúde no município de São Paulo, intitulado como "momento I", acontece após seis meses ou mais de contratação. Outros treinamentos junto à equipe de saúde são graduais, executados em períodos semanais, que duram pouco mais de duas horas. Com isso, ao voltar os olhos novamente ao gráfico 6 , é possível notar que mais de $1 / 3$ dos ACS, 37\%, possuem menos de um ano de trabalho, Informação que será considerada na análise das ações referidas pelo ACS.

É possível constatar que mais da metade dos ACS, 57\%, está vinculado a atividades com igrejas. Este dado é justificado pela forte tradição do bairro, formado inicialmente por imigrantes italianos, que confessavam sua fé nas doutrinas da igreja 
católica. Atualmente estas igrejas possuem grande atuação no campo do assistencialismo, por meio de projetos de alfabetização de jovens e adultos, cursos profissionalizantes, doação de cestas básicas, etc. Por este fato, o envolvimento dos moradores do bairro nos eventos religiosos muitas vezes não se justifica exclusivamente pela concordância doutrinária, mas sim, pelos benefícios sociais oferecidos.

Outro dado que chama a atenção é não haver referência alguma à participação do ACS no Conselho Tutelar, apenas 7\%, ou seja, um (1) ACS à participação em Associação de Bairro e novamente 7\% em Associação de Pais, refletindo, talvez, as características sócio-econômicas da Região Central do município, em que a maior parte dos membros familiares está inserida no mercado de trabalho, restando pouco tempo para outras atividades, a considerar as participações em instituição da comunidade.

Destaca-se, ainda, com três dos ACS entrevistados, referência a outras atividades na comunidade, entre as quais está filiação partidária política (delegada de rua) com uma (1) referência, participação em grupo comunitário relacionado à saúde com uma (1) referência e dirigente de grupo familiar (Testemunha de Jeová) com igual referência. Três ACS se abstiveram de responder a questão, indicando um índice de $18,7 \%$ do total dos investigados.

\subsection{AS COMPETÊNCIAS MAIS PRESENTES NO COTIDIANO DO ACS}

Nesta etapa do trabalho utilizou-se o instrumento desenvolvido por Santos (2005), construído sobre as competências/habilidades propostas pelo Ministério da Saúde desenvolvidas pelo ACS:

[...] "O instrumento de coleta de dados baseou-se nas competências/habilidades esperadas do ACS, segundo o proposto pelo Ministério da Saúde. As habilidades foram decodificadas em ações pela pesquisadora a fim de facilitar a leitura pelos ACS e buscar respostas mais objetivas, haja vista que há interfaces entre as ações descritas como integrantes de uma competência que poderiam causar certa dificuldade nas respostas. Cada ação foi baseada no item citado no documento, não tendo a pesquisadora interferência na distribuição das ações por categoria" $[. . .]^{(18)}$. 
As competências propostas pelo Ministério da Saúde ${ }^{(14)}$ aos ACS são:

- Integração da equipe com a população local (Categoria A)

- Planejamento e avaliação (Categoria B)

- Promoção da Saúde (Categoria C)

- Prevenção e monitoramento de risco ambiental e sanitário (Categoria D)

- Prevenção e monitoramento a grupos específicos e morbidades (Categoria E)

Para cada competência, a autora desse instrumento descreveu determinadas ações que pudessem explorar o dia a dia de trabalho do ACS. Na competência de Integração da equipe com a população local, por exemplo, foram decodificadas dez atividades. Atividades essas que, segundo Santos (2005):

[...] "Estão relacionadas principalmente com as ações relativas ao comportamento da equipe, a integração entre os "componentes" e com a comunidade, bem como o desenvolvimento de ações relacionadas ao preenchimento de instrumentos de trabalho (Ficha $A, B$, e C) e orientações dadas" $[\ldots]^{(18)}$.

O gráfico a seguir mostra o conjunto de ações de Integração da equipe com a população local. 


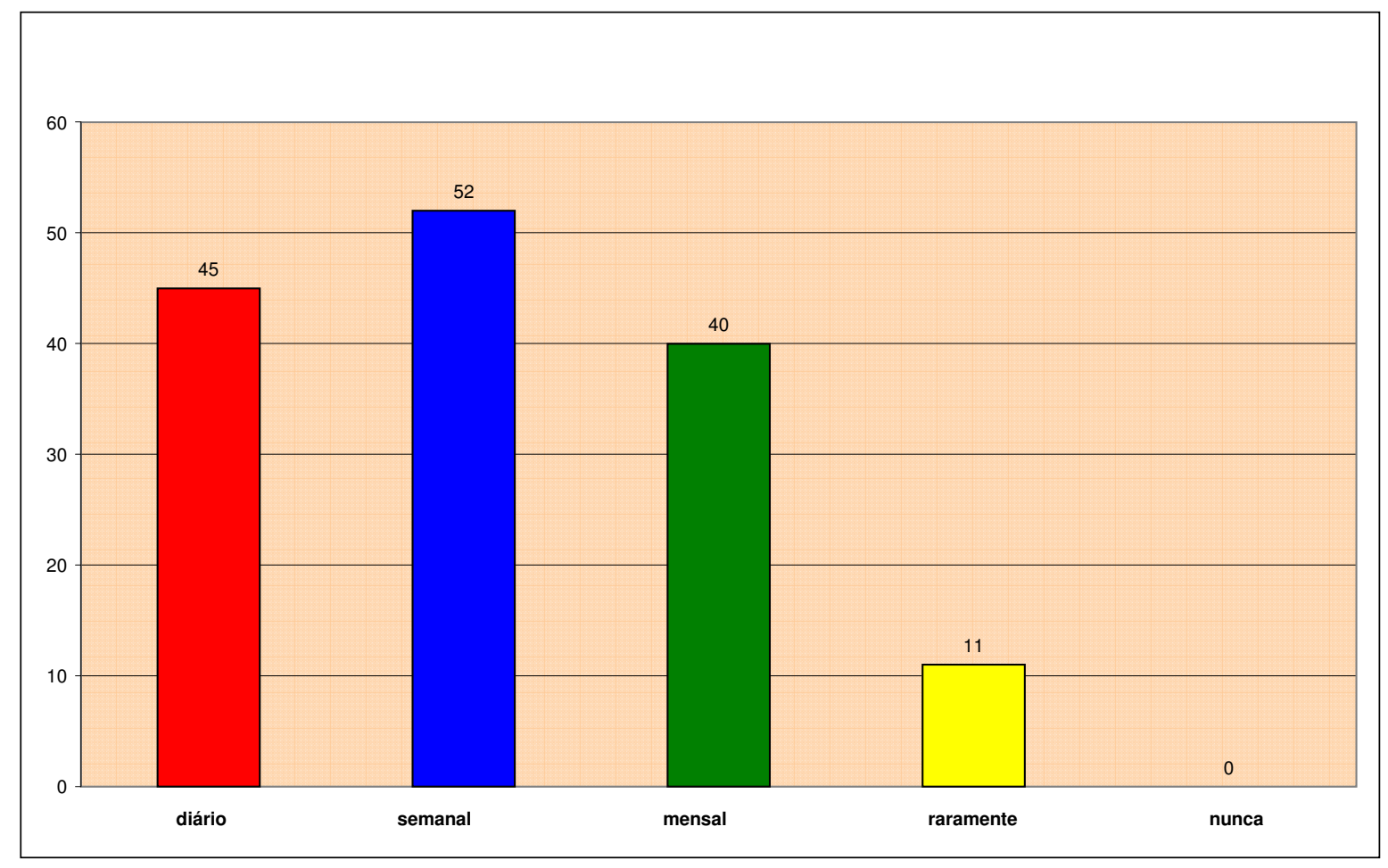

Gráfico 5 - 0 conjunto de ações de integração da equipe com a população local. (1ำ eixo de competências do ACS).

Com relação a esta competência, o gráfico 5 expõe que semanalmente, 35,1\% das ações vinculadas à competência INTEGRAÇÃO DA EQUIPE COM A POPULAÇÃO LOCAL são realizadas pelo ACS. Algumas ações relacionadas à sexta competência, esperava-se que ocorresse na freqüência semanal e mensal. 30,4\% das ações descritas são realizadas diariamente, e $27 \%$ das ações são realizadas mensalmente. Chamam à atenção, mesmo com uma pequena parcela de $7,4 \%$, as atividades raramente realizadas, entre as quais está a de expor suas opiniões nas reuniões de equipe.

O gráfico a seguir refere-se a uma ação do eixo de competência, integração da equipe com a população local: expor a opinião (do ACS) nas reuniões em equipe. 


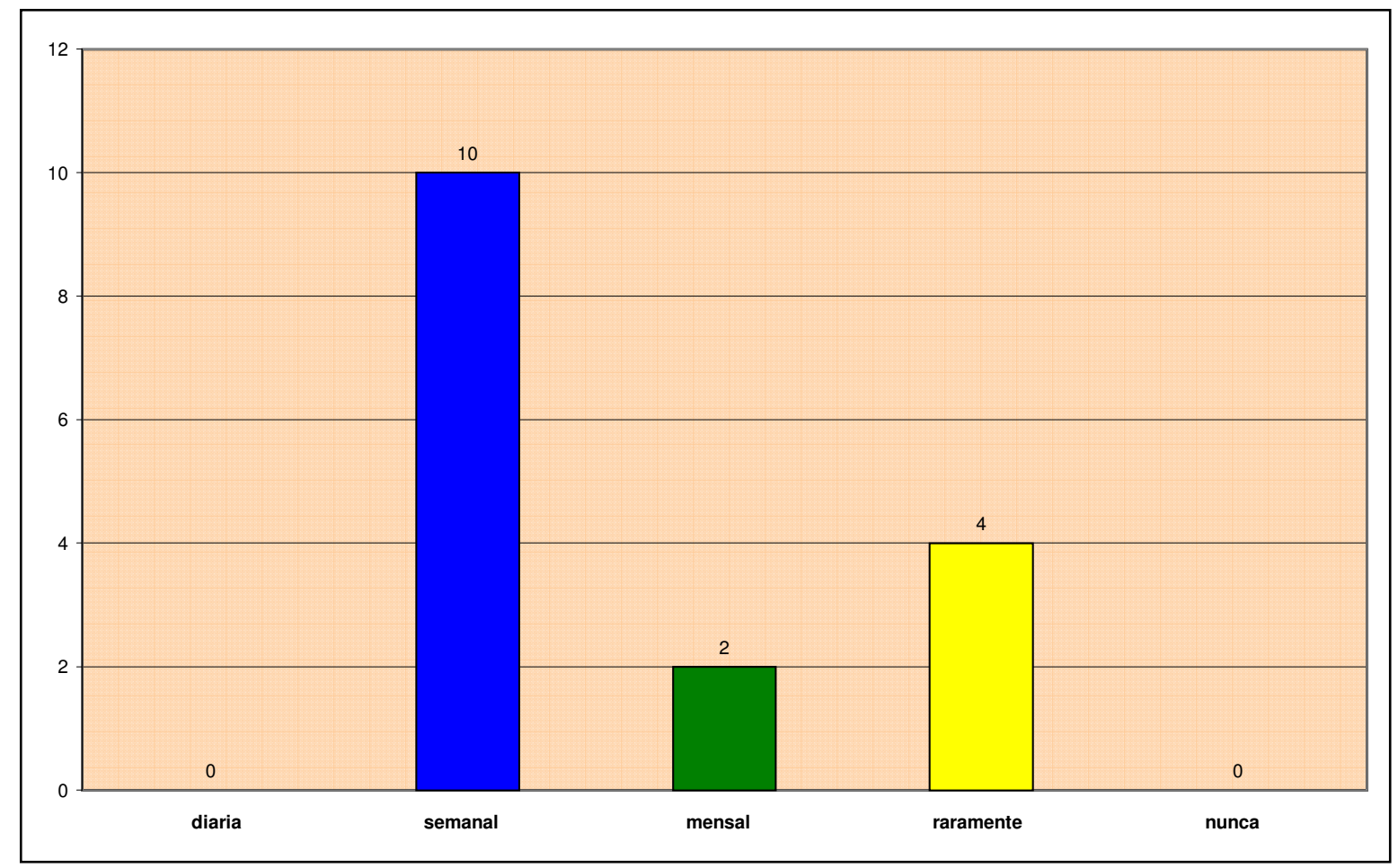

Gráfico 6 - Refere-se a ação de expor a opinião do ACS nas reuniões em equipe (esta ação pertence ao $1^{\circ}$ eixo de competências do ACS).

No que se refere à participação dos ACS na exposição de suas idéias pode-se observar que dez (10) ACS, (62,5\%), referiram realizá-la semanalmente, quatro (4) relataram que raramente (25\%) a realizam e $12,5 \%$, ou seja, dois (2) dos investigados, mensalmente o faziam. Com isso é possível constatar que a maioria dos ACS acredita expor sua opinião em reuniões de equipe.

Tomando-se como base que as atividades de INTEGRAÇÃO DA EQUIPE COM A POPULAÇÃO LOCAL podem estar distribuídas entre as freqüências diária, semanal e mensal, conclui-se, então, que a maioria dessas atividades, é frequentemente realizada pelo ACS, apesar de ter-se observado que determinadas ações raramente são realizadas.

A próxima competência a ser relatada, refere-se ao Planejamento e Avaliação.

Num total de treze atividades de PLANEJAMENTO E AVALIAÇÃO descritas por Santos (2005), essas atividades estão vinculadas à: observação crítica e alerta do profissional (ACS) sobre o território de sua micro-área, sobre os riscos sociais, sobre os riscos ambientais e sobre os dados do cadastramento; o estabelecimento de 
ações conjuntas a sua comunidade e sua equipe, bem como o uso de meios de avaliação das ações ${ }^{(18)}$.

O gráfico a seguir mostra o conjunto das ações de planejamento e avaliação.

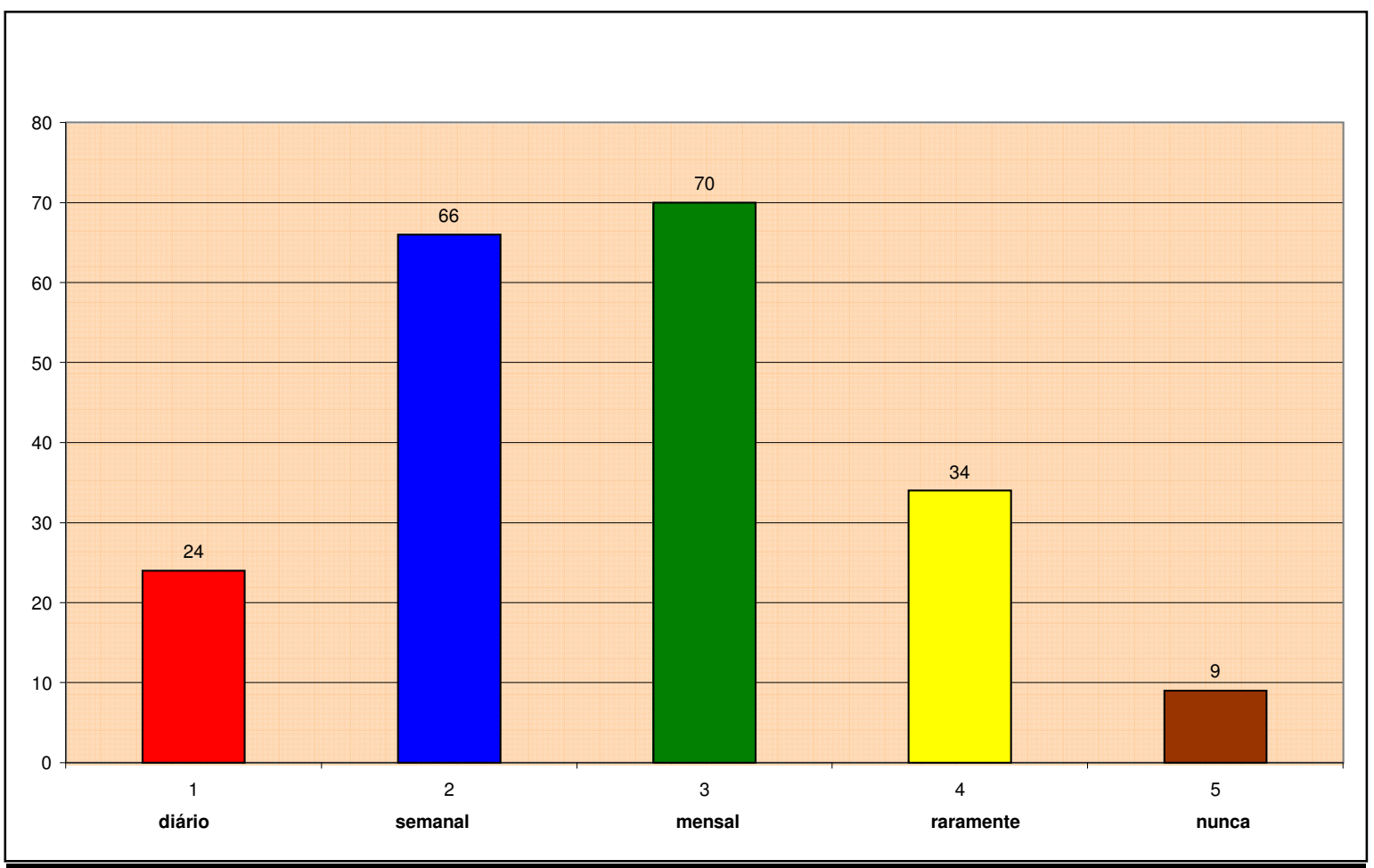

Gráfico 7 - $O$ conjunto de ações de Planejamento e avaliação ( $2^{\circ}$ eixo de competências do ACS).

O gráfico 7 demonstra que $34,4 \%$ das atividades de planejamento e avaliação são realizadas pelos ACS mensalmente, 32,5\% semanalmente, 16,7\% raramente, $11.8 \%$ diariamente e $4,4 \%$ das atividades nunca são realizadas. A partir dessa informação se faz necessária uma avaliação mais atenta dos resultados desse gráfico no que se refere às respostas raramente e nunca, buscando suas causas.

O gráfico a seguir mostra uma ação do segundo eixo de competência do ACS (Planejamento e avaliação): informar à comunidade os resultados obtidos no levantamento sobre a saúde da população. 


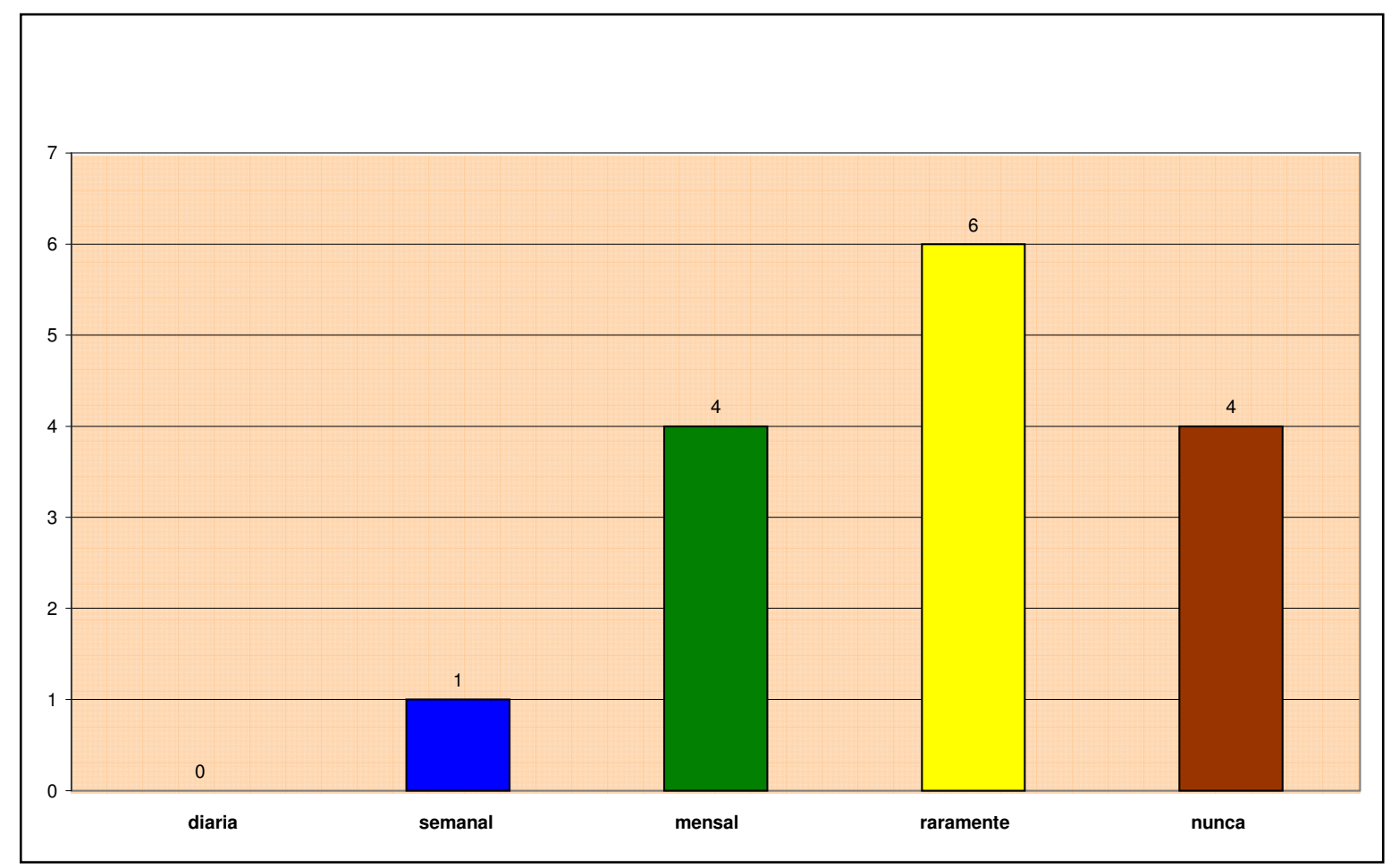

Gráfico 8 - Ação do $2^{\circ}$ eixo de competências: informa à comunidade os resultados obtidos no levantamento sobre a saúde da população.

Em relação à divulgação dos resultados do levantamento de saúde da população, observa-se que $40 \%$ dos ACS, raramente informam à comunidade, seis ACS, e 26,6\% nunca informam quatro ACS. Fazendo parte de um grupo menor, quatro ACS (26,6\%), mensalmente informam e $6,6 \%$, ou seja, um ACS informa semanalmente. Fica claro que essa é uma atividade pouco realizada pelo ACS, já que mais da metade dos profissionais referiram que raramente ou nunca a praticaram. Esse dado demonstra que apesar da maioria das atividades da competência: PLANEJAMENTO E AVALIAÇÃO serem realizadas mensal, semanal e diariamente, os dados obtidos, fruto do trabalho do ACS, não são compartilhados com a comunidade, retratando que a estratégia de aproximar os índices de saúde aos usuários é pouco aplicada entre estes profissionais.

O próximo gráfico refere-se ao terceiro eixo de competência do ACS: conjunto de ações de Promoção da Saúde 


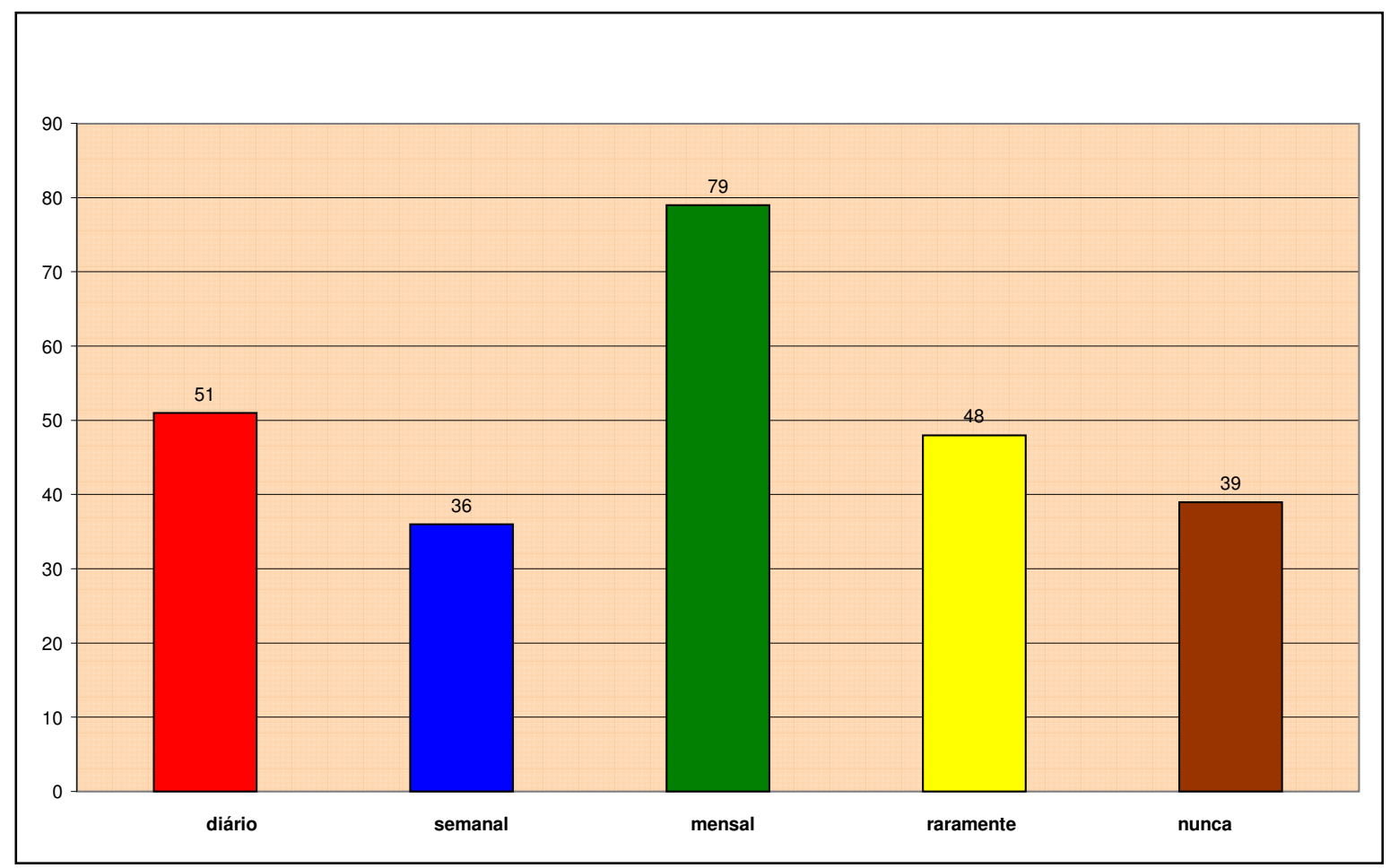

Gráfico 9 - Conjunto de ações de Promoção da Saúde (3ํeำo de competências do ACS)

No que se refere às ações de PROMOÇÃO DA SAÚDE, observa-se aqui a freqüência mensal de 31,22\% e 20,15\%, de freqüência diária. Logo após, encontramse as ações de promoção da saúde que raramente são realizadas, com 18,97\%, as nunca realizadas, com $15,41 \%$ e com menor freqüência as ações semanalmente praticadas, com 14,22\%. Nota-se, com exceção da freqüência mensal, que ocorre uma distribuição quase uniforme das atividades de Promoção da Saúde entre as freqüências diária, semanal, raramente e nunca, apontando que o ACS pratica $34,38 \%$ das ações diária ou semanalmente e $34,38 \%$ raramente ou nunca praticam as expostas ações de promoção.

Por ser esta competência a que mais interessa a essa pesquisa, apresentarse-á, a seguir, a freqüência com que as ações que constituem esta competência, ocorrem na perspectiva dos ACS, assim o gráfico a seguir nos mostra a ação de identificar a relação entre os problemas de saúde e condições de vida. 


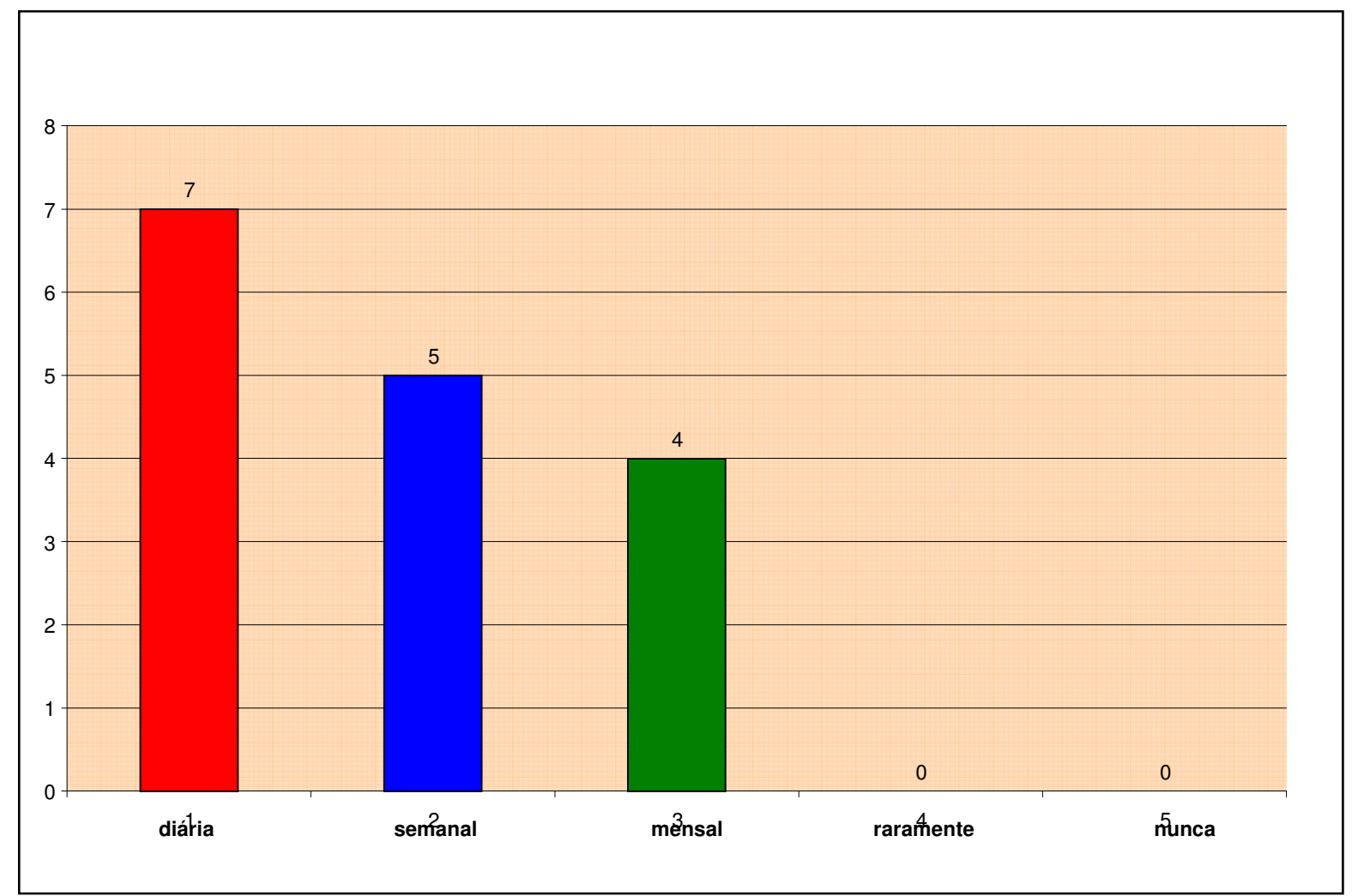

Gráfico 10 - 1ª Ação de Promoção da Saúde: identifica a relação entre problemas de saúde e condição de vida.

O gráfico 10 revela que a ação de promoção da saúde a qual identifica a relação dos problemas de saúde com as condições de vida é valorizada. Aponta para a freqüência diária, como a mais indicada pelo ACS com sete (7) indicações, obtendo um percentual de 43,7\%, sendo que semanal, esta ação, consta com cinco (5) indicações, ou seja, 31,2\% e a mensal com quatro indicações, (25\%). Observa-se, portanto, que essa ação é frequentemente realizada, o que é corroborado pelo dado de que essa ação é raramente ou nunca é realizada pelos ACS. Desta forma, supõese que o ACS, por acreditar que há relação entre os problemas de saúde e as condições de vida, claramente observa na comunidade em que trabalha e vive a interligação entre essas duas situações.

O gráfico a seguir refere-se a segunda ação de Promoção da Saúde: identifica exemplos positivos que promovam a saúde da comunidade. 


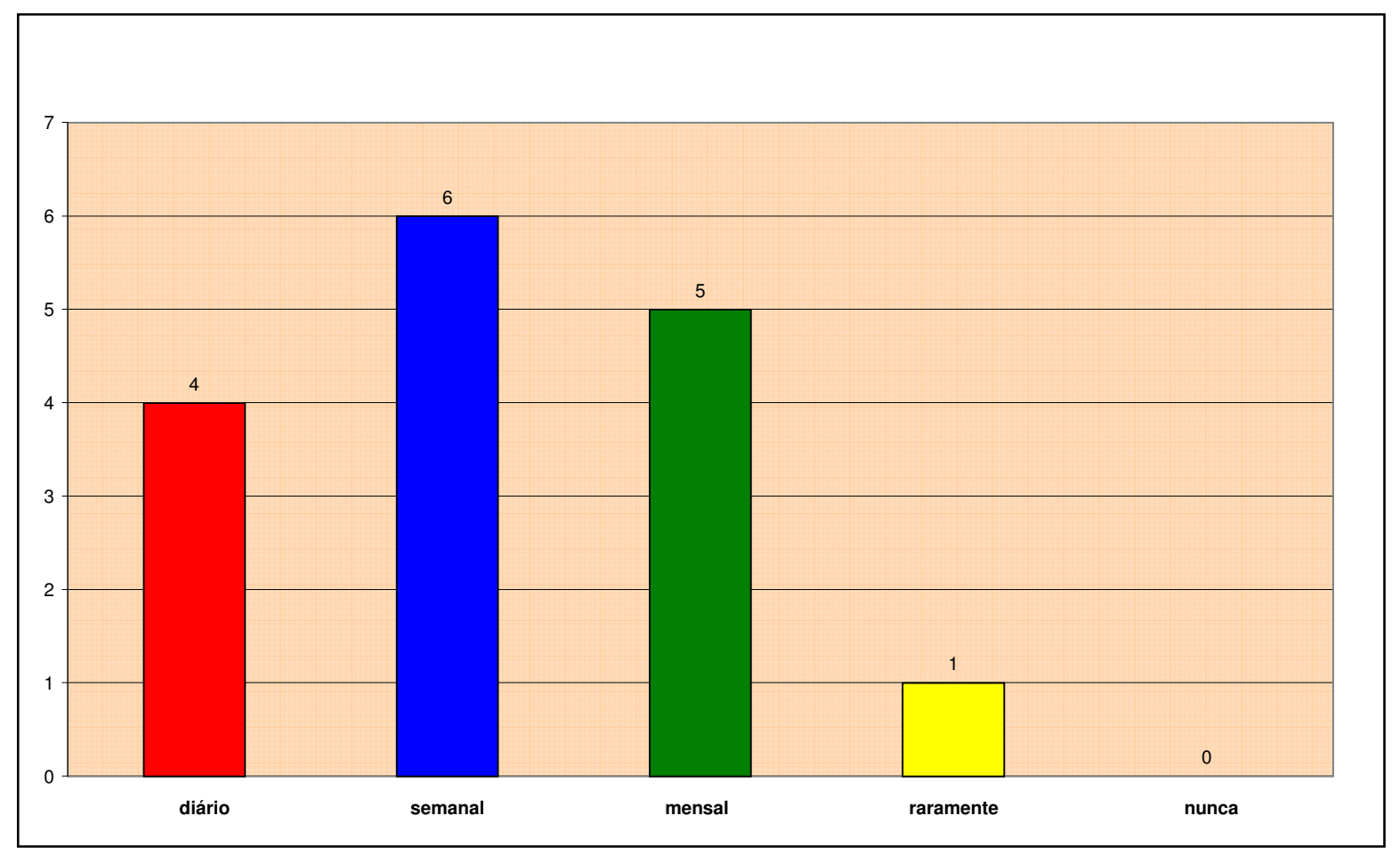

Gráfico 11 - 2a ação de Promoção da Saúde: identifica exemplos positivos que promovem a saúde da comunidade.

No próximo gráfico 11 é possível notar que a ação semanal do ACS voltada para identificação de exemplos positivos que promovem a saúde da comunidade consta de $37,5 \%$ do total das indicações, com seis indicações. A freqüência mensal vem em seguida com 31,2\% mostrando que cinco ACS executam essa ação de promoção apenas uma vez ao mês. A freqüência diária encontra-se com a baixa indicação de $25 \%$, quatro ACS e 6,2\%, ou seja, um (1) ACS diz que raramente realiza tal ação. A expectativa para esta ação é que seja realizada diariamente, já que o campo de ocorrência é a visita domiciliar e essa ocorre todos os dias.

O gráfico a seguir representa a terceira ação de Promoção da Saúde: realiza atividades educativas para a comunidade (palestra, campanhas, mutirões, etc.) juntamente com o enfermeiro. 


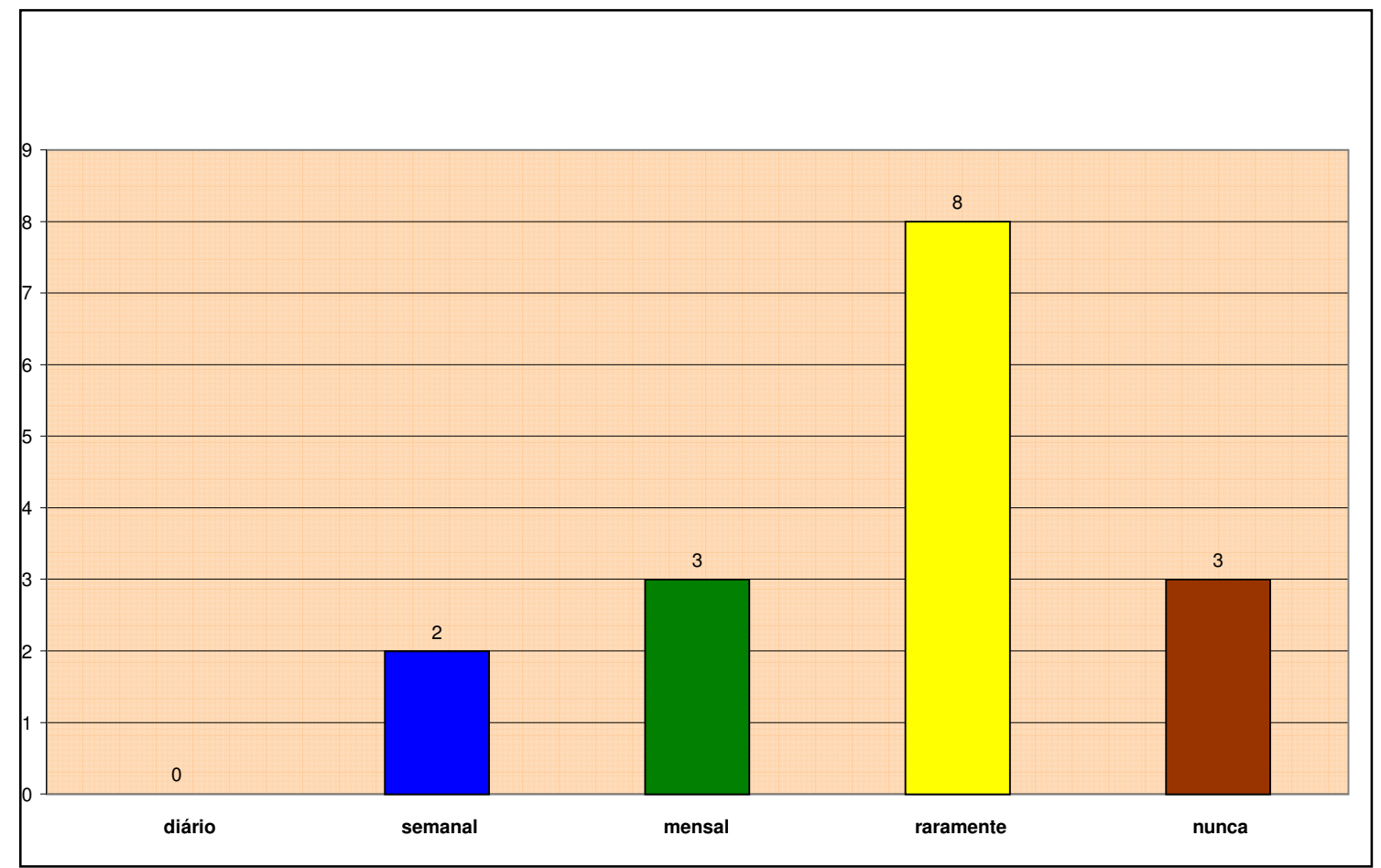

Gráfico 12 - 3a ação de Promoção da Saúde: realiza atividades educativas para a comunidade (palestras, campanhas, mutirões, etc) juntamente com o enfermeiro.

Ao analisar o gráfico 12 nota-se que 50\%, dos ACS, oito (8) indicações, raramente realizam atividades educativas com o enfermeiro, constata-se também que $18,7 \%$, três ACS, nunca realizam tal tarefa. Por ser uma atividade esperada com maior freqüência mensal, a indicação de quase $70 \%$ dos ACS não praticarem ou raramente praticarem essa ação revela um importante dado para a investigação qualitativa. Três ACS relatam que mensalmente executam esta ação, (18,7\%) e, dois ACS, (12,5\%) realizam-na semanalmente.

O próximo gráfico refere-se à quarta ação de Promoção da Saúde: realiza atividades educativas com outro ACS. 


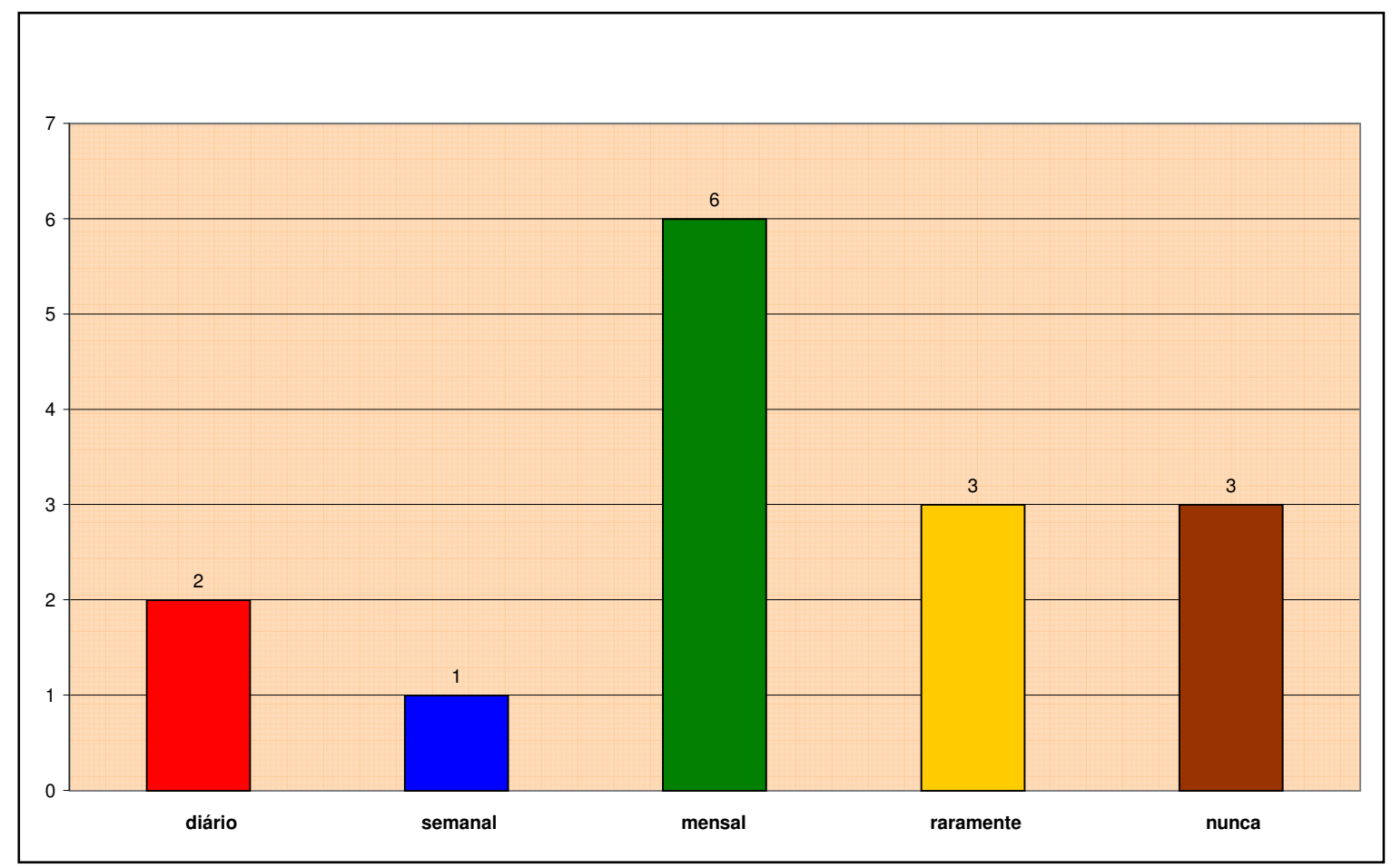

Gráfico 13 - 4⿳a ação de Promoção da Saúde: realiza atividades educativas com outro ACS.

Este gráfico 13 revela que $40 \%$ praticam atividade educativa com outros ACS mensalmente, ou seja, seis (6) ACS, mas para 20\%, três (3) ACS essa prática é raramente realizada e outros $20 \%$, três (3) ACS indicam que nunca o fazem. A atividade educativa por meio de palestras ou grupos educativos é esperada com maior freqüência mensal, o que está representado neste gráfico. Entretanto há uma incoerência nos dados no que se refere à freqüência diária de 13,3\% e a semanal de $6,6 \%$. Como é possível realizar todas as visitas domiciliares às famílias, se diariamente é praticada a atividade educativa, a qual consome um tempo considerável, impossibilitando, talvez, que todas as famílias sejam visitadas no mês.

O gráfico a seguir refere-se a quinta ação de Promoção da Saúde: realiza atividades educativas para a comunidade sozinho. 


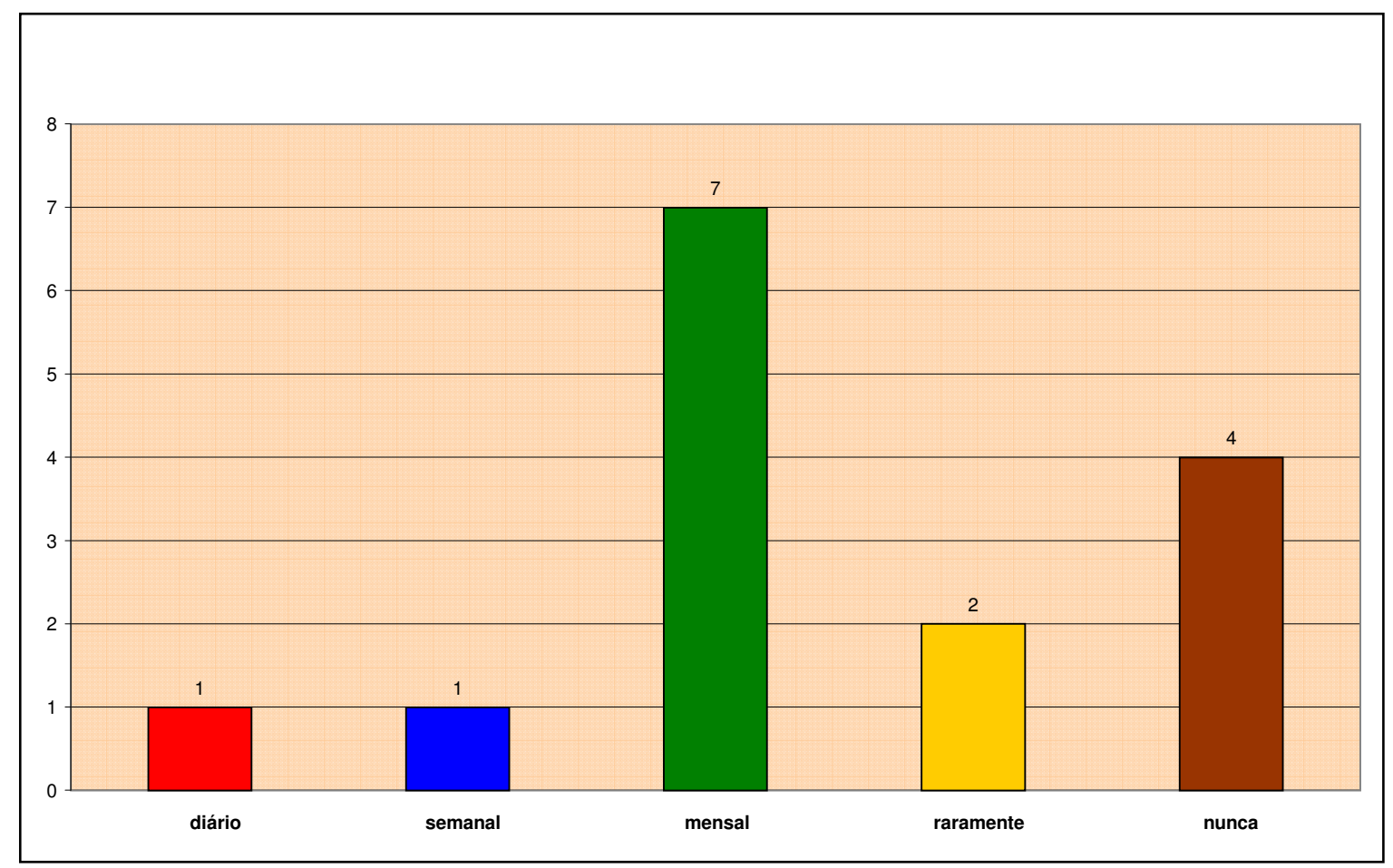

Gráfico 14 - 5a ação de Promoção da Saúde: realiza atividades educativas para a comunidade sozinho.

Ao comparar o gráfico 14 com o anterior, nota-se que a freqüência mensal e a freqüência nunca realizada obtiveram um pequeno aumento, respectivamente $46,6 \%$, sete (7) ACS e 26,6\%, quatro (4) ACS. Esse fato revela que é mais freqüente o ACS realizar atividade educativa com a comunidade sozinho, do que com o enfermeiro ou outro ACS. No gráfico 14, a maior parte dos ACS mensalmente realiza, individualmente, atividades educativas com a comunidade, mas $40 \%$ do total do grupo, seis (6) ACS, raramente ou nunca executam tal atividade, apontando a formação de dois pólos: os que realizam atividade educativa sozinho (60\%) sejam essas diária, semanal ou mensalmente, e os que raramente ou nunca realizam (40\%).

Uma outra ação de Promoção da Saúde é a de utilizar recursos de informação e comunicação adequados á realidade local e, pode ser visualizado no gráfico a seguir. 


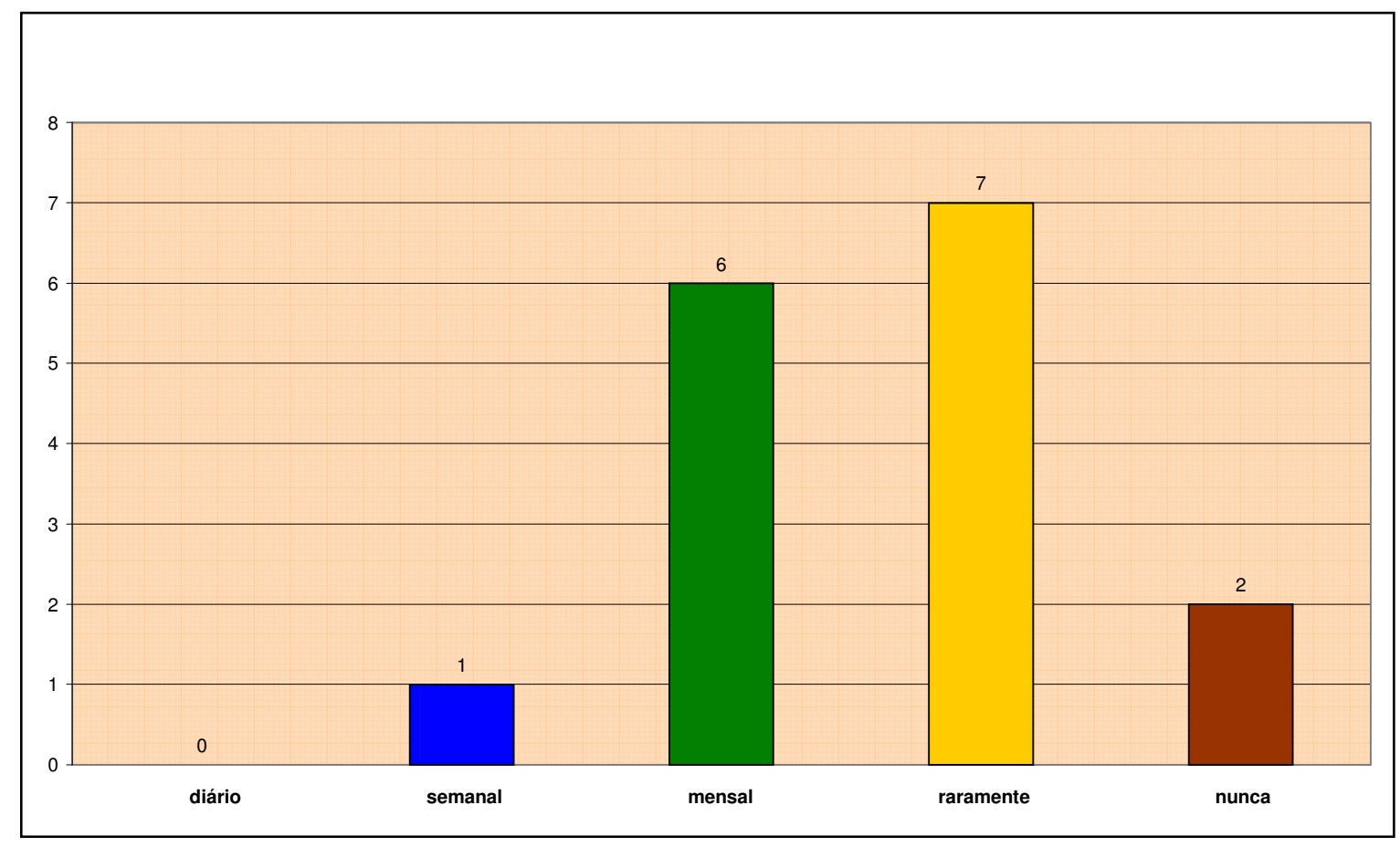

Gráfico 15 - 6ª ação de Promoção da Saúde: utiliza recursos de informação e comunicação (faixas, panfletos, etc) adequados à realidade local.

Este gráfico 15 traz importante revelação: há um baixo aproveitamento dos recursos disponíveis para auxiliar na atividade educativa, pois $43,7 \%$ dos ACS, sete (7) referências, raramente utilizam recursos de informação e comunicação adequados à realidade local e 12,5\%, duas referências, nunca o usam, Em contra partida, observa-se que $37,5 \%$, ou seja, seis (6) ACS usam mensalmente desses recursos e $6,25 \%$, um único ACS, o utilizam semanalmente. Novamente dois pólos são formados, 56,3\% dos ACS, raramente ou nunca utilizam os recursos existentes para fazer educação em saúde e 43,7\% mensalmente ou semanalmente fazem uso destes recursos.

Com relação a sétima ação de Promoção da Saúde: estimula os indivíduos e comunidade a refletirem sobre sua condições de saúde e doença, o gráfico a seguir nos mostra o forma de sua ocorrência. 


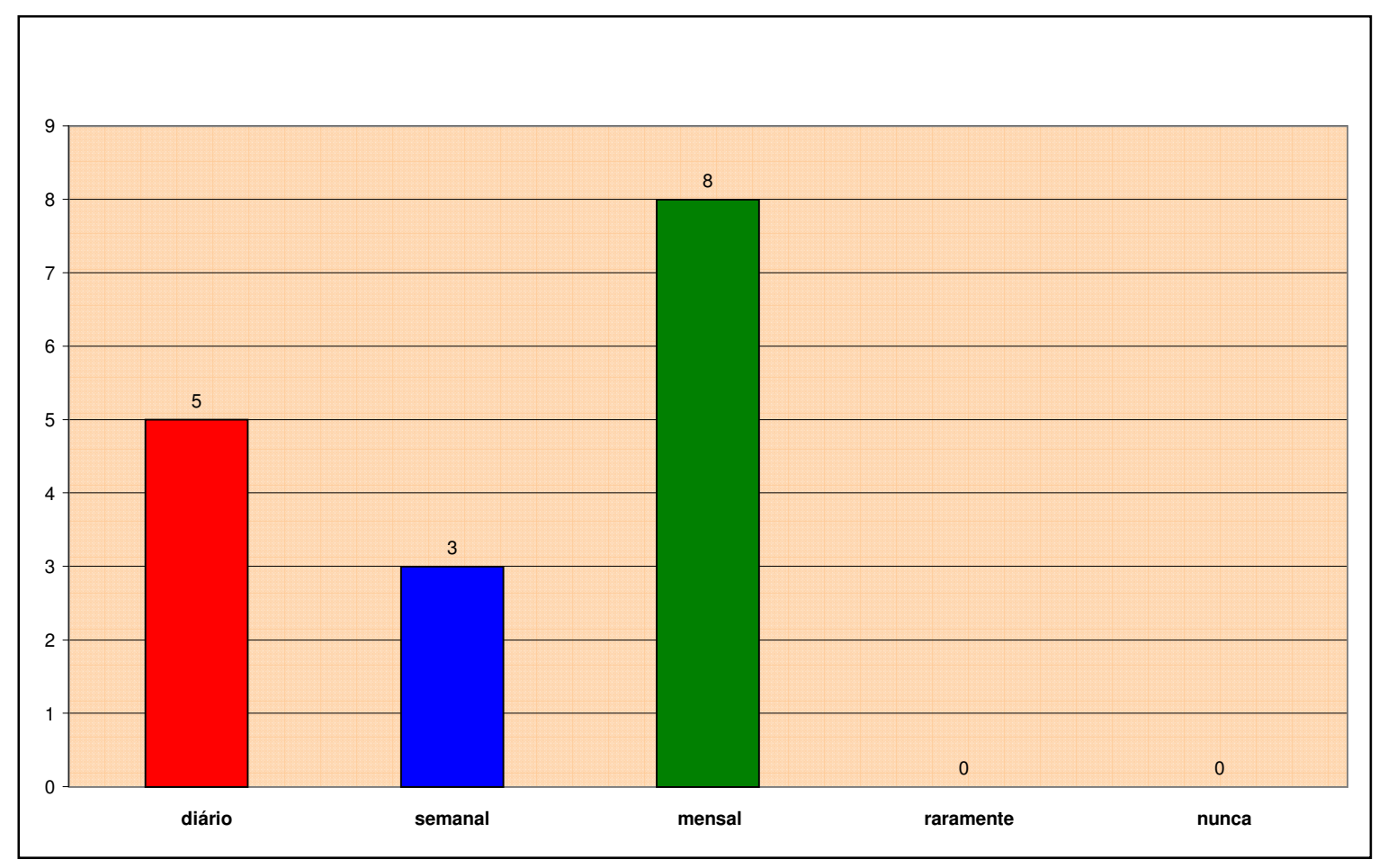

Gráfico 16 - 7ª ação de Promoção da Saúde: estimula os indivíduos e comunidade a refletirem sobre as suas condições de saúde e doença.

A metade dos entrevistados, oito (8) ACS, revelam que mensalmente estimulam os indivíduos e comunidade a refletirem sobre as suas condições de saúde e doença. 31,2\%, cinco (5) ACS, realizam essa ação diariamente e 18,7\%, três (3) ACS, semanalmente, apontando para uma ação praticada por todos os profissionais, seja esta diária, semanal ou mensalmente. O que chama a atenção é que com a freqüência mensal para esta ação, considerando que este profissional possui em média 150 famílias, levará em média seis meses para refletir sobre as condições de saúde e doença em todos os domicílios, já que ele realiza teoricamente, no mínimo uma visita mensal para cada família.

Uma outra questão a ser formulada é de que forma o ACS encaminha essa reflexão sobre a condição de saúde, se numa perspectiva crítica no sentido de levar as pessoas a correlacionarem as condições de vida e trabalho ao seu perfil de saúdedoença, ou se numa perspectiva mais idealista de identificar fatores de risco e, culpabilizar as famílias pelas condições das mesmas.

Com relação a oitava ação de Promoção da Saúde: orienta os indivíduos quanto ao auto cuidado, o gráfico a seguir esclarece como se dá o perfil de sua realização. 


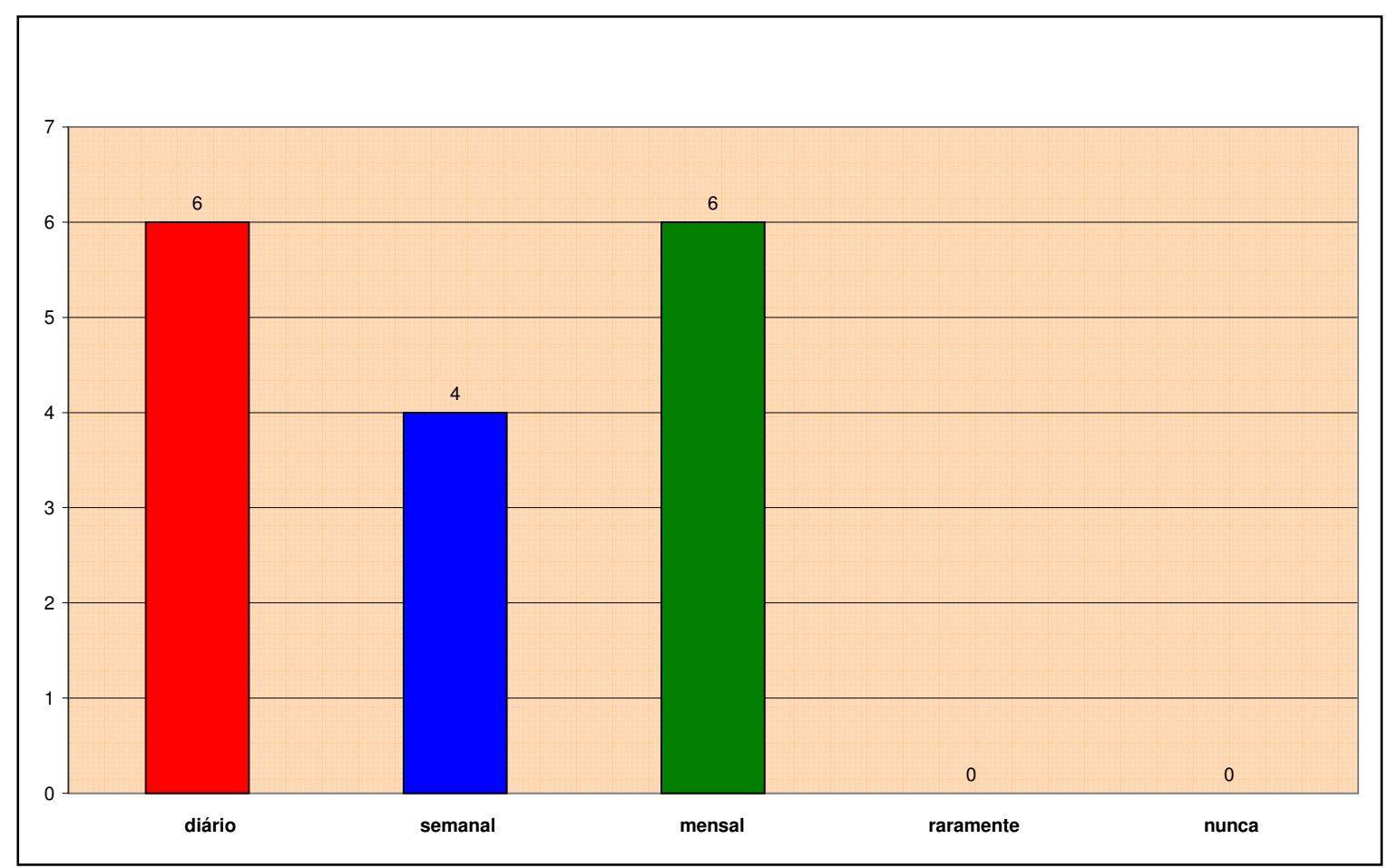

Gráfico 17 - 8a ação de Promoção da Saúde: orienta os indivíduos quanto ao auto cuidado.

Este gráfico 17 também chama a atenção para a freqüência, em que seis (6) ACS $(37,5 \%)$ relatam a orientação aos indivíduos quanto ao auto cuidado apenas uma vez ao mês. Na freqüência diária o índice também é de seis (6) ACS (37,5\%) e semanalmente de quatro (4) ACS (25\%). É possível verificar que as freqüências diária e semanal são as mais referidas pelo ACS, indicando ser essa uma ação continuamente realizada.

A seguir apresenta-se o gráfico 18 com a nona ação de Promoção da Saúde do ACS: orienta quanto a medidas de proteção à saúde (alimentação, higiene pessoal, limpeza, acondicionamento e destino do lixo, cuidados com a água e dejetos, e outros). 


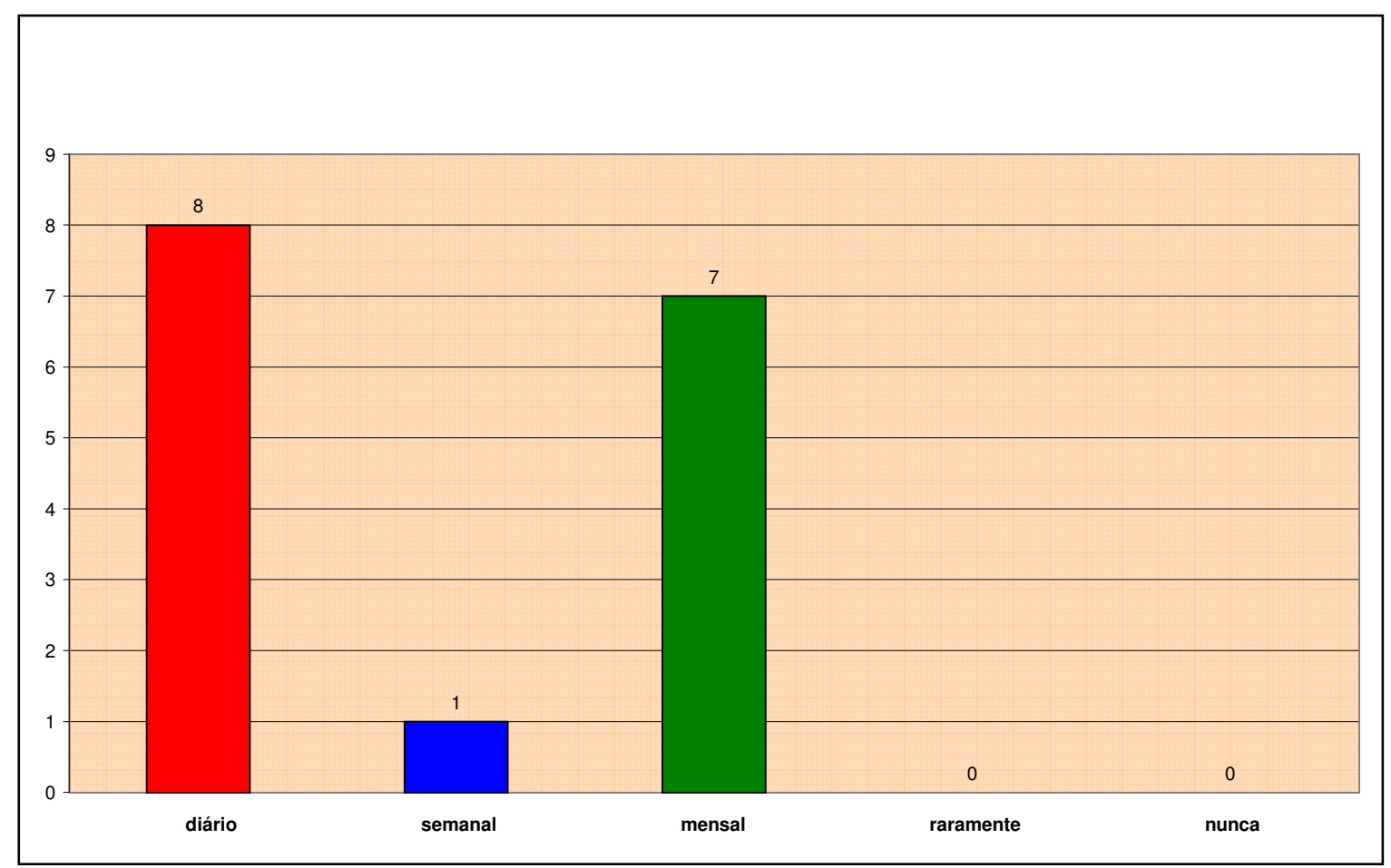

Gráfico 18 - 9a ação de Promoção da Saúde: orienta quanto a medidas de proteção à saúde (alimentação, higiene pessoal, limpeza, acondicionamento e destino do lixo, cuidados com a água e dejetos, e outros).

Diariamente, oito (8) ACS (50\%) orientam a população quanto a medidas de proteção à saúde, sete (7) orientam mensalmente (43,7\%) e um (1) ACS orienta semanalmente. A alta incidência mensal revela que a orientação à população sobre alimentação, higiene pessoal, limpeza, acondicionamento e destino do lixo, cuidados com a água e dejetos, entre outros é uma ação de baixa freqüência para mais de $40 \%$ dos ACS.

O gráfico a seguir mostra a décima ação de Promoção da Saúde do ACS: orienta indivíduos e família quanto às medidas de prevenção de acidentes domésticos. 


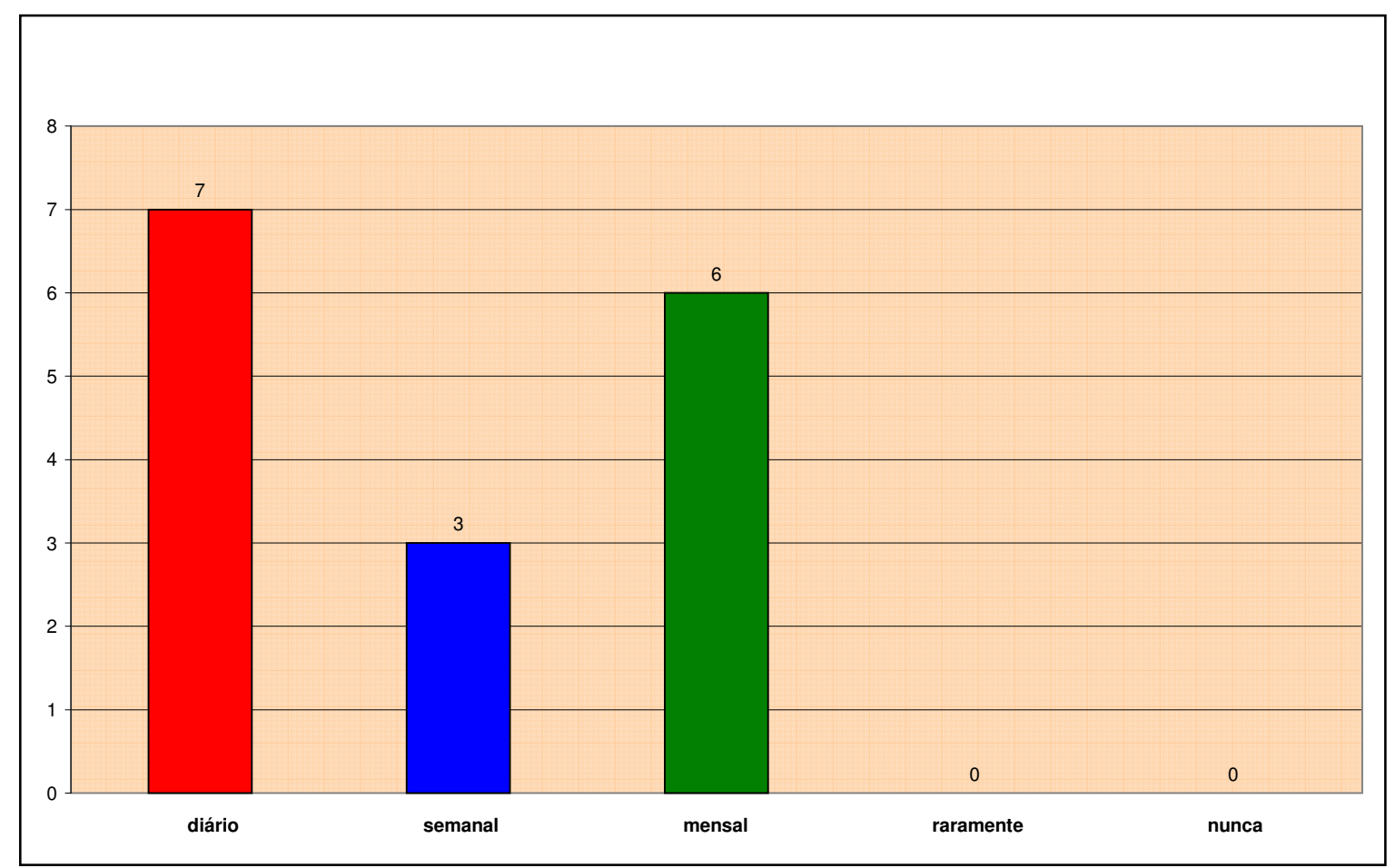

Gráfico 19 - 10a ação de Promoção da Saúde: orienta indivíduos e família quanto as medidas de prevenção de acidades domésticos.

As medidas de prevenção de acidentes requerem uma atenção especial do ACS, revelando um olhar atento para o comportamento da família e constante observação aos possíveis locais ou situações de acidente em domicílio. Este gráfico 19 demonstra que sete (7) ACS (43,7\%) diariamente orientam indivíduos e família para a prevenção de acidentes domésticos, seis (6) orientam somente uma vez ao mês $(37,5 \%)$ e três (3) ACS o fazem toda semana (18,7\%). O alto índice mensal dessa ação revela uma baixa freqüência em quase metade dos ACS investigados.

O próximo gráfico mostra a décima primeira ação de Promoção da Saúde do ACS: propõem ações que utilizem as diversas secretarias no município. 


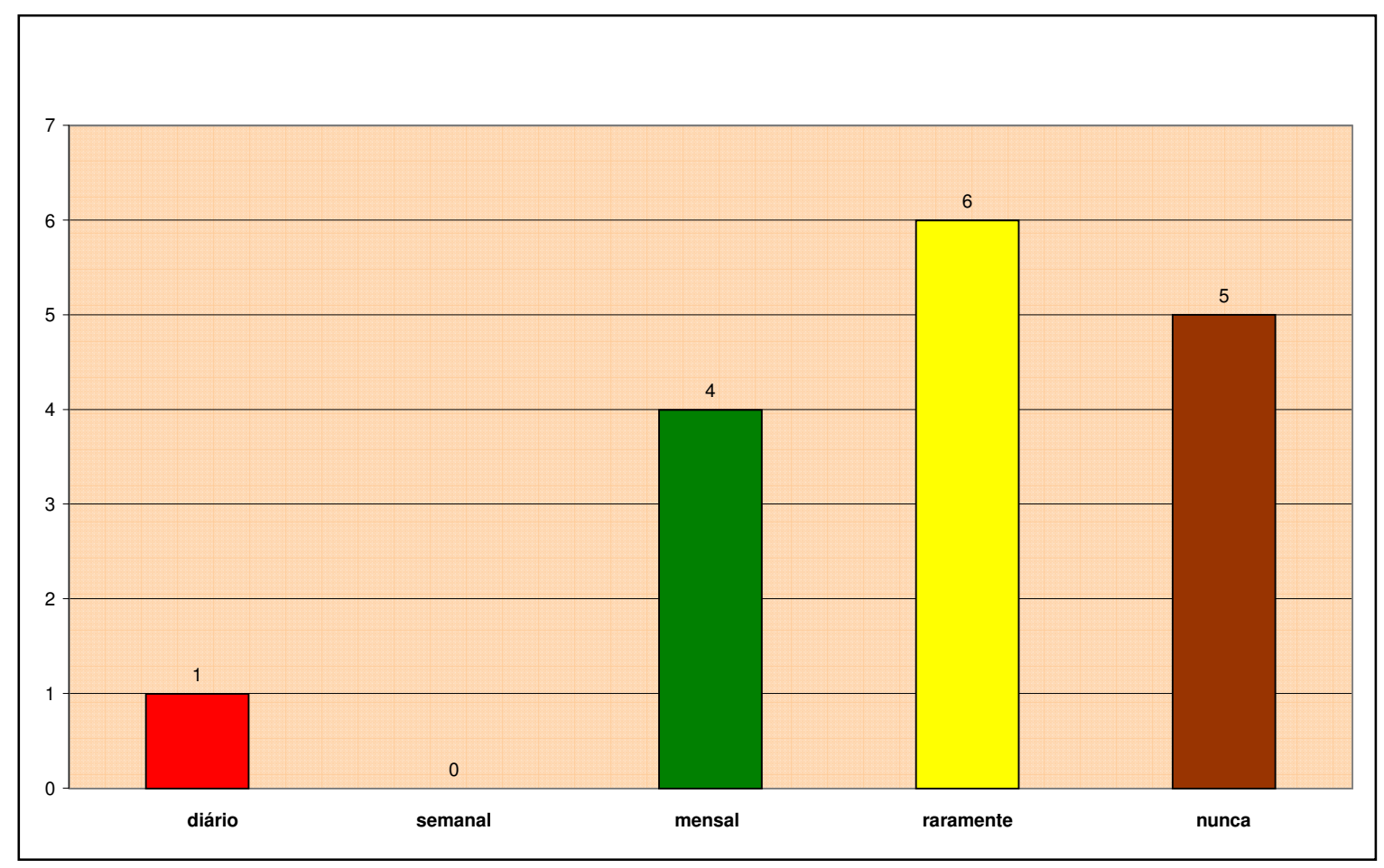

Gráfico 20 - 11aa ação de Promoção da Saúde: propõem ações que utilizem as diversas secretarias existentes no município.

As ações conjuntas entre as distintas secretarias municipais fazem parte das medidas de promoção da saúde e colaboram para uma visão ampliada do processo saúde-doença, em que o individuo é captado no seu cotidiano. Nota-se que seis (6) ACS $(37,5 \%)$ raramente propõem ações que utilizem as diversas secretarias existentes no município e seis (6) nunca as realizam $(31,2 \%)$, apontando para um alto índice (68,7\%), ou seja, onze (11) ACS que não praticam tal ação. Os demais relatos revelam que quatro (4) destes profissionais $(25 \%)$ realizam essa mensalmente e $6,25 \%$, ou seja, um único ACS pratica diariamente.

Verifica-se a seguir o gráfico com a décima segunda ação de Promoção da Saúde do ACS: executa ações que atuam em parceria com outras Secretarias existentes no município. 


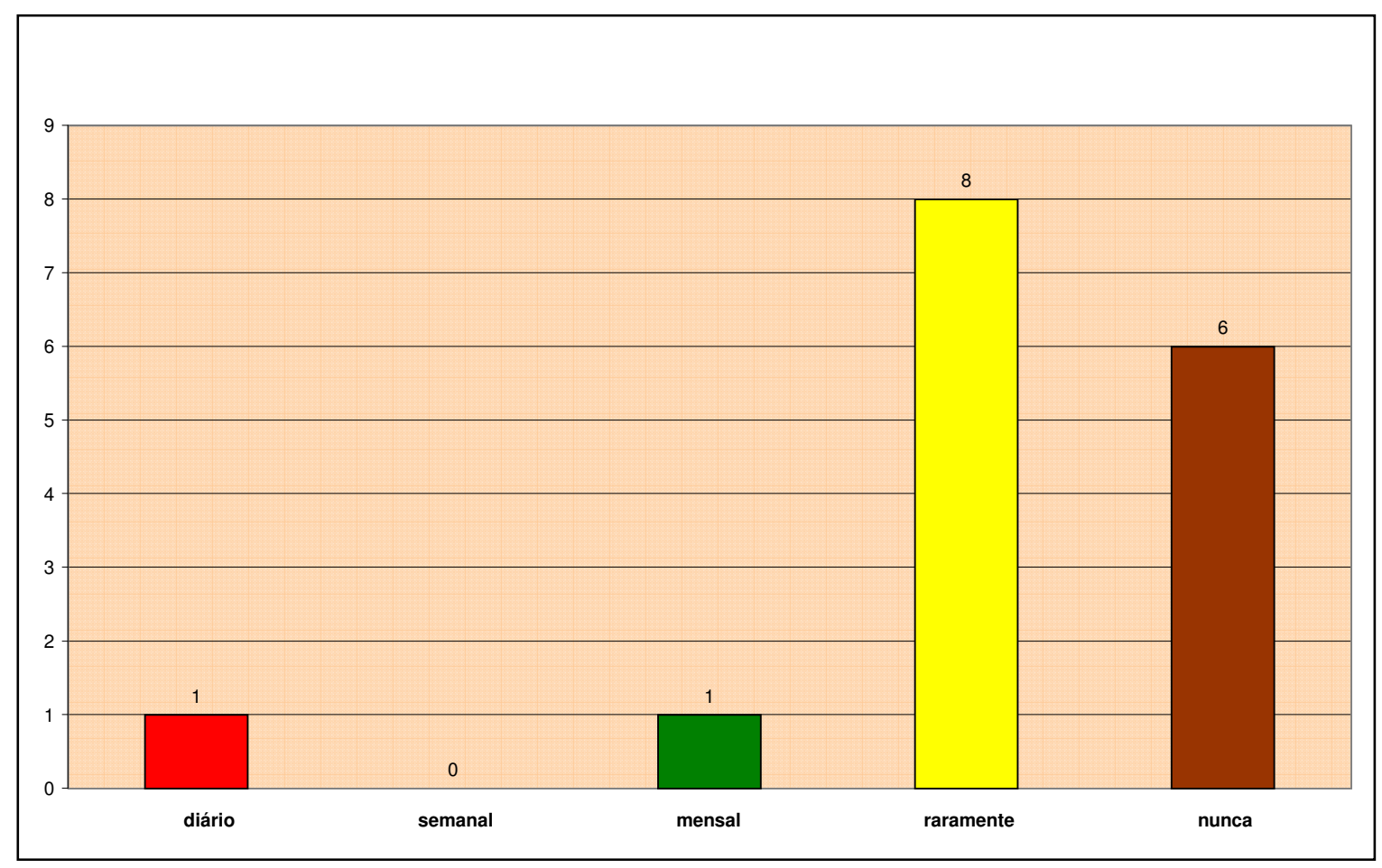

Gráfico 21 - 12a ação de Promoção da Saúde: executa ações que atuam em parceria com outras Secretarias existentes no município.

Nesse gráfico 21 os índices são ainda mais alarmantes, pois demonstram que oito (8) ACS (50\%) raramente executam ações que atuem em parceria com outras secretarias existentes no município e seis (6) ACS nunca a executam (37,5\%), resultando um total de $87,5 \%$ dos profissionais, ou seja, quatorze (14) ACS. Apenas dois relatos distribuídos entre as freqüências diária e mensal, apontando para 6,25\% cada um. A análise desses índices revela que a maioria dos ACS não realizam essa ação como freqüência e reproduzem no âmbito do micro espaço do trabalho, a desarticulação inter-setorial existente no âmbito do macro espaço e das políticas públicas.

O gráfico a seguir expõe a décima terceira ação de Promoção da Saúde do ACS: estabelecem parcerias com creches, asilos, escolas, comércios, grupos sociais e outros. 


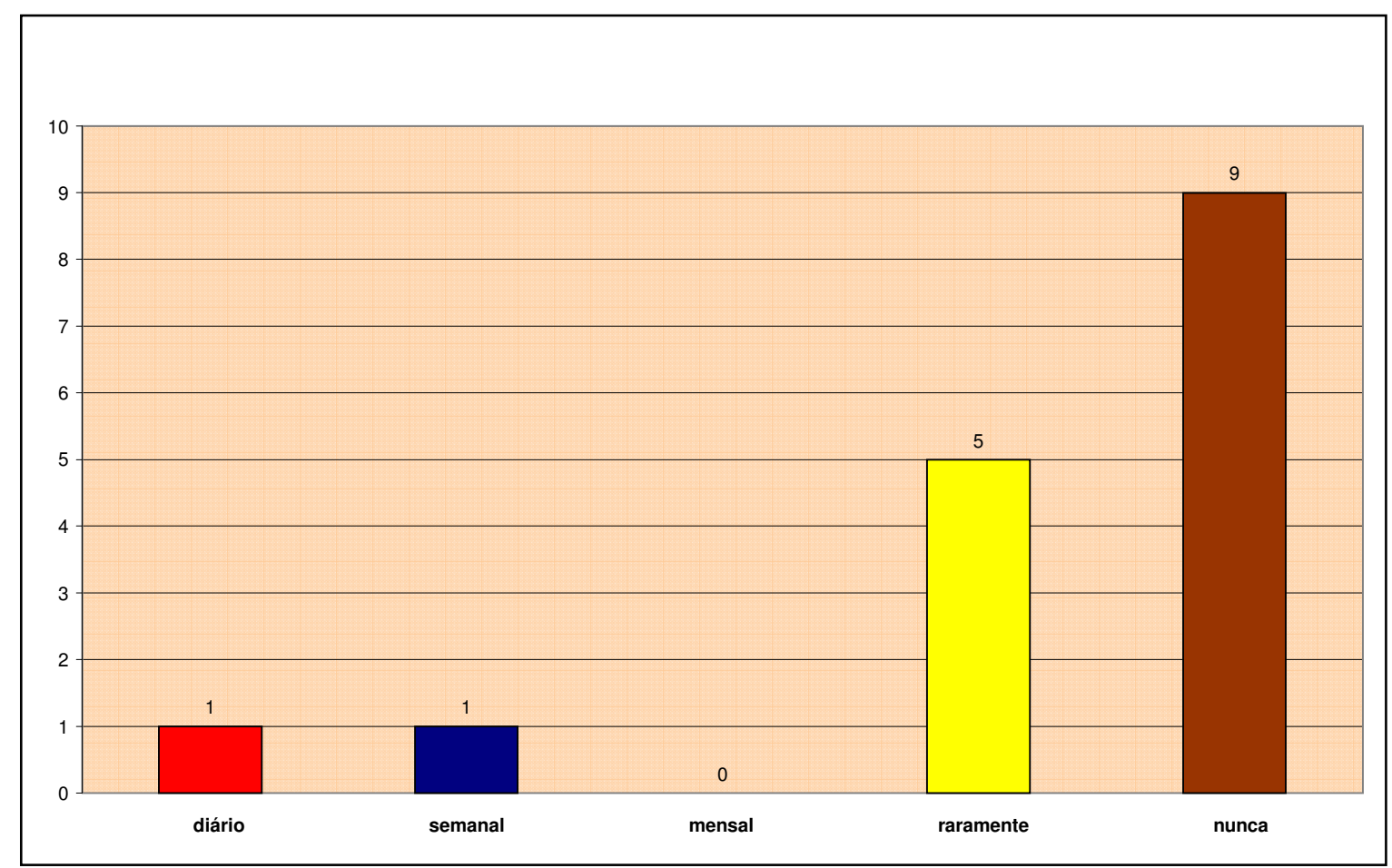

Gráfico 22 - 13a ação de Promoção da Saúde: estabelecem parcerias com creches, asilos, escolas, comércios, grupos sociais e outros.

Estabelecer parcerias com creches, asilos, escolas, comerciantes, grupos sociais e outros requer habilidade em reconhecer a instituição ou o grupo social como aliados nas ações de promoção da saúde. Essa ação indica uma visão de empowerment comunitário, observando dessa maneira que, nove (9) ACS (56,2\%) nunca realizam esta ação e cinco (5) raramente a praticam $(31,2 \%)$. Igualmente ao gráfico anterior identificam-se dois ACS que estabelecem parcerias com as instituições ou grupos sociais, sendo um (1) diariamente e um (1) semanalmente.

O gráfico seguinte refere-se à décima quarta ação de Promoção da Saúde do ACS: orienta a família e ou portador de necessidades especiais quanto às medidas facilitadoras para a sua máxima inclusão social. 


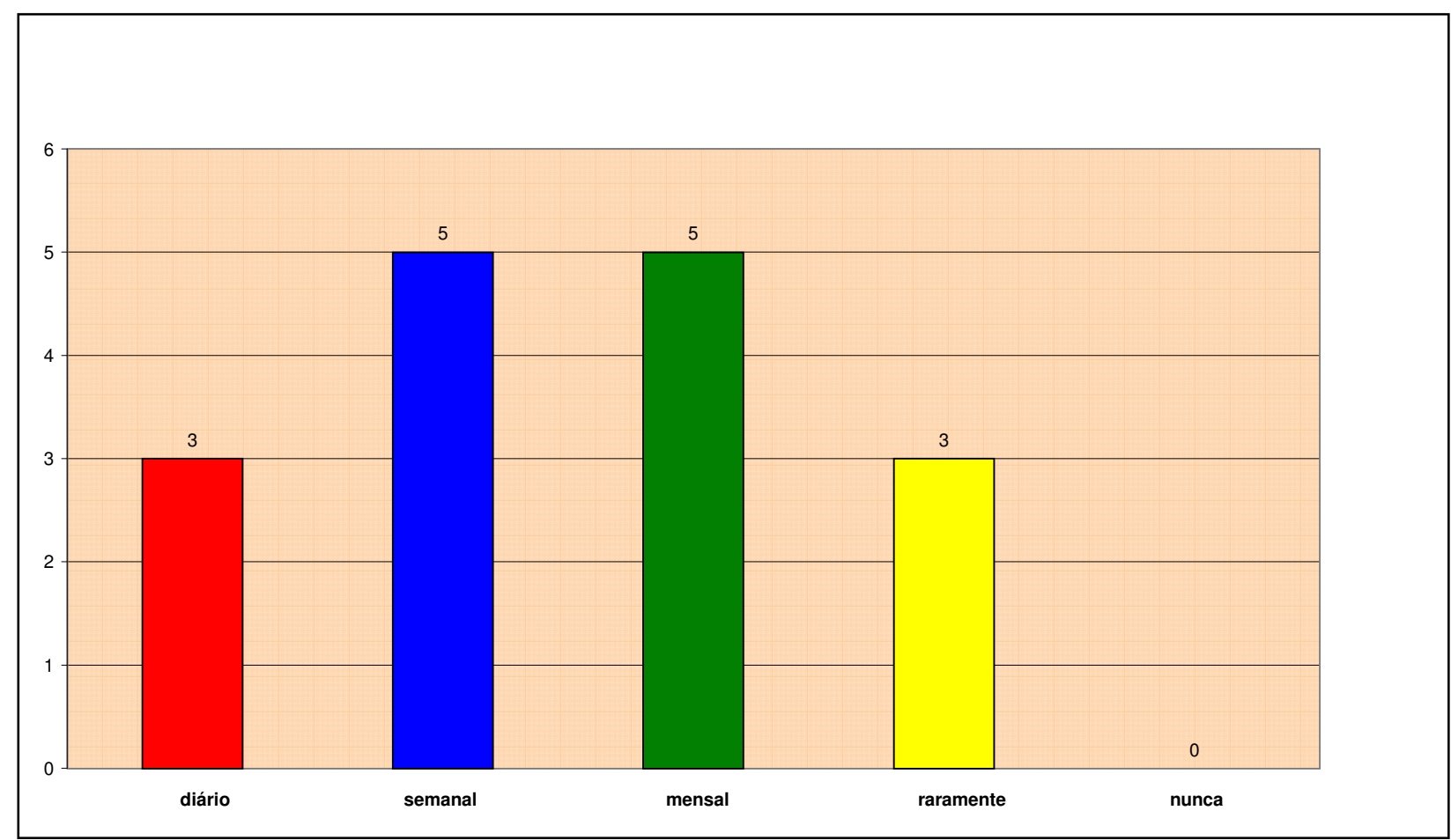

Gráfico 23 - 14a ação de Promoção da Saúde: orienta a família e ou portador de necessidades especiais quanto às medidas facilitadoras para a sua máxima inclusão social.

Aparentemente, ações que envolvem orientações à família são mais freqüentes entre os ACS investigados. De acordo com o gráfico 23, cinco (5) profissionais, semanalmente, orientam a família e ou portador de necessidades especiais quanto às medidas facilitadoras para a sua máxima inclusão social $(31,2 \%)$. Com o mesmo índice (31,2\%), cinco (5) ACS realizam essa ação mensalmente e três (3) ACS diariamente (18,7\%). Considerando que a freqüência dessa ação está relacionada ao número de portadores de necessidades especiais existente em cada micro-área, não é possível precisar a freqüência ideal para essa ação. Finalmente, encontra-se um índice de três (3) ACS (18,7\%) que raramente orientam seus cadastrados.

Verifica-se no gráfico 24 a décima quinta ação de Promoção da Saúde do ACS: apóia ações de alfabetização de crianças, adolescentes, jovens e adultos. 


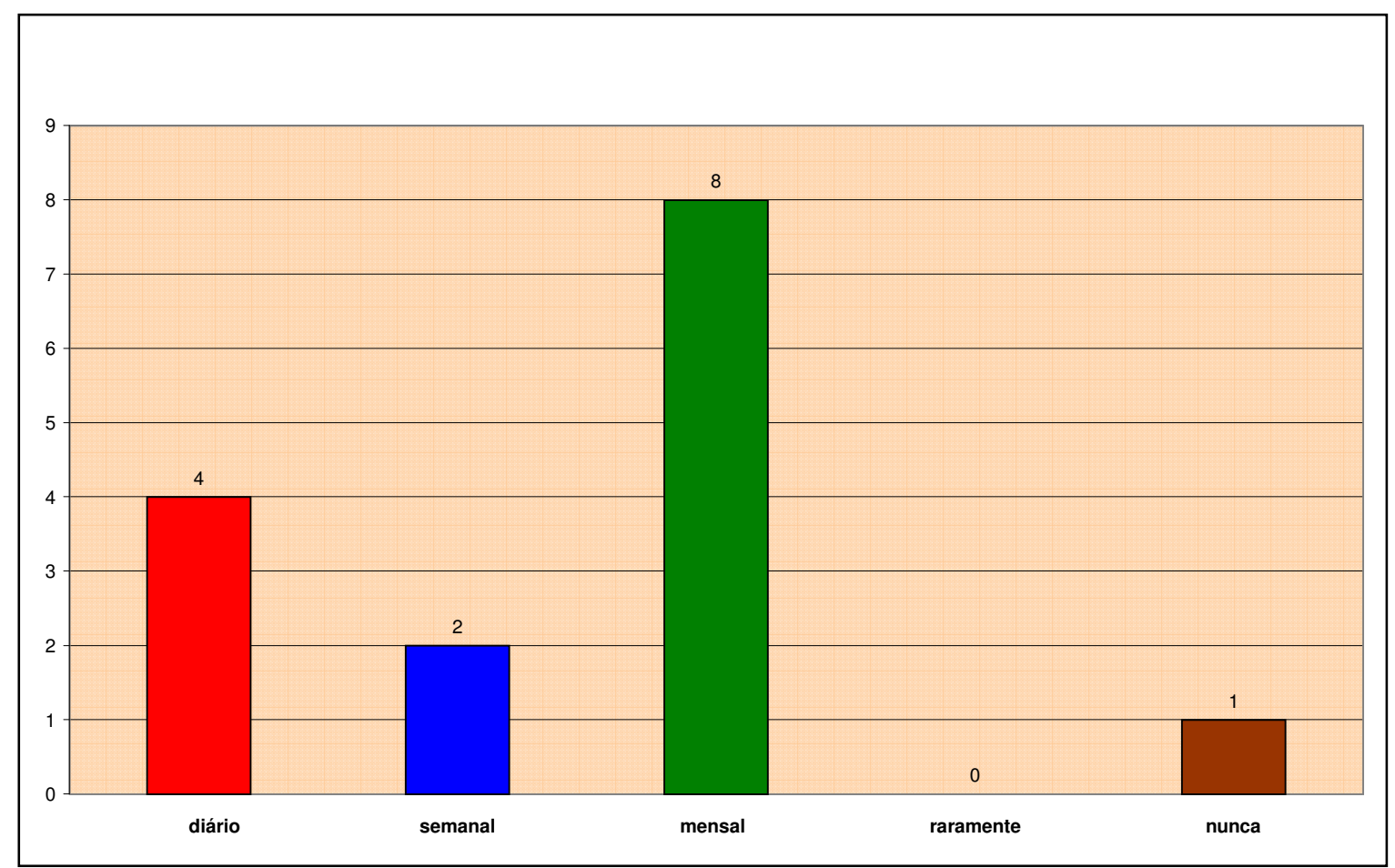

Gráfico 24 - 15ª ação de Promoção da Saúde: apóia ações de alfabetização de crianças, adolescentes, jovens e adultos.

O apoio às ações sociais de alfabetização de crianças, adolescentes, jovens e adultos pode ser interpretado de algumas maneiras: desde o incentivo à participação do indivíduo nas instituições que oferecem tais ações até a cooperação com as mesmas. Essas diferentes interpretações podem influenciar na resposta. Observa-se, no entanto, um índice de oito (8) ACS na freqüência mensal desta ação $(53,3 \%)$, revelando aderência por parte dos ACS. Quatro (4) ACS encontram-se na freqüência diária $(26,6 \%)$ e dois (2) ACS na semanal. Apenas um ACS relata que nunca realiza essa ação.

O gráfico a seguir refere-se a décima sexta ação de Promoção da Saúde do ACS: participa de reuniões do conselho local de saúde ou outro conselho local. 


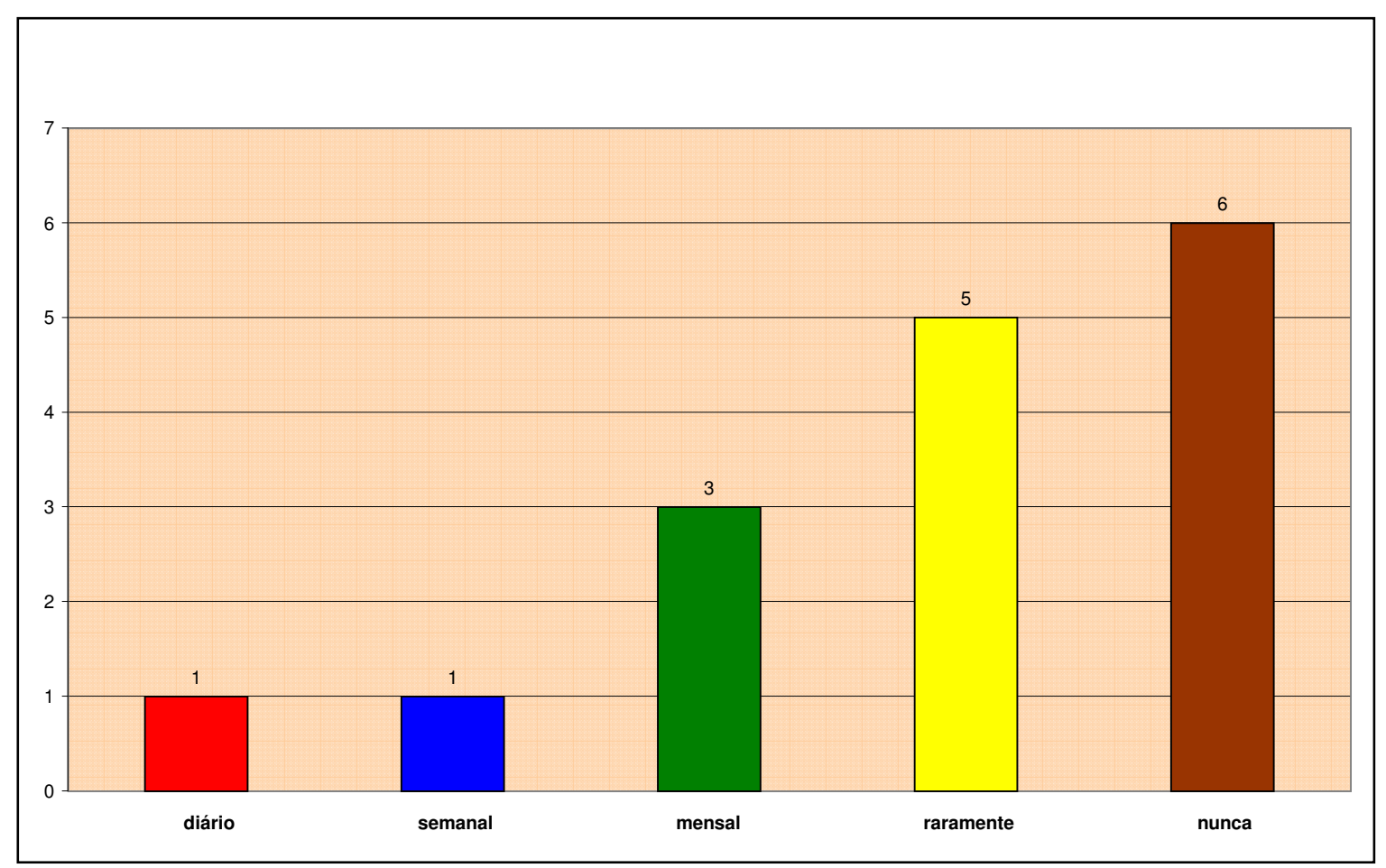

Gráfico 25 - 16a ação de Promoção da Saúde: participa de reuniões do conselho local de saúde ou de outro conselho local.

As reuniões do conselho local de saúde ou outros conselhos locais acontecem normalmente uma vez ao mês. O conselho local de saúde é uma das formas de desenvolver o empowerment da comunidade, permitindo, de forma coletiva, que a população defina as necessidades de saúde da localidade. Apesar disso nota-se que dois (2) ACS referem participar do conselho, um diariamente e outro semanalmente. O gráfico revela ainda que seis (6) ACS nunca participam destas reuniões (37,5\%), cinco (5) raramente participam $(31,2 \%)$ e três (3) ACS participam mensalmente $(18,7 \%)$, o que demonstra a baixa participação do ACS nesse tipo de atividade.

O próximo gráfico refere-se o conjunto de ações do quarto eixo de competência do ACS: Prevenção e monitoramento de risco ambiental e sanitário. 


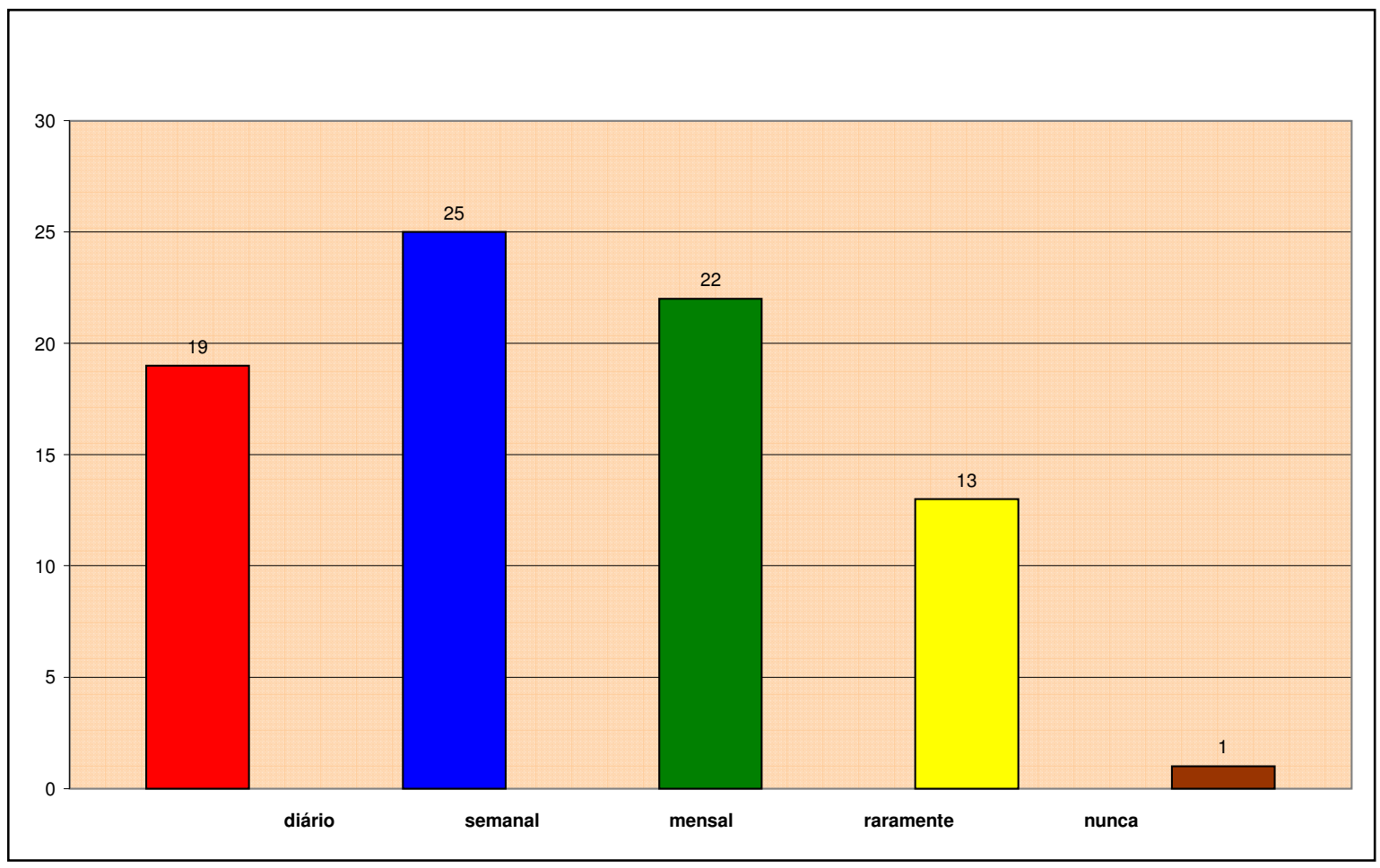

Gráfico 26 - 4 Eixo de Competência do ACS: Prevenção e monitoramento de risco ambiental e sanitário.

O conjunto das ações de prevenção e monitoramento de risco ambiental e sanitário foi retratado no gráfico acima, revelando que $31,25 \%$ dessas ações, são referidas semanalmente, $27,5 \%$ mensalmente, $23,75 \%$ diariamente, $16,25 \%$ raramente e $25 \%$ dessas ações nunca são realizadas.

O gráfico a seguir mostra as ações de prevenção e monitoramento de risco ambiental e sanitário e com que freqüência ocorre na prática do ACS. 


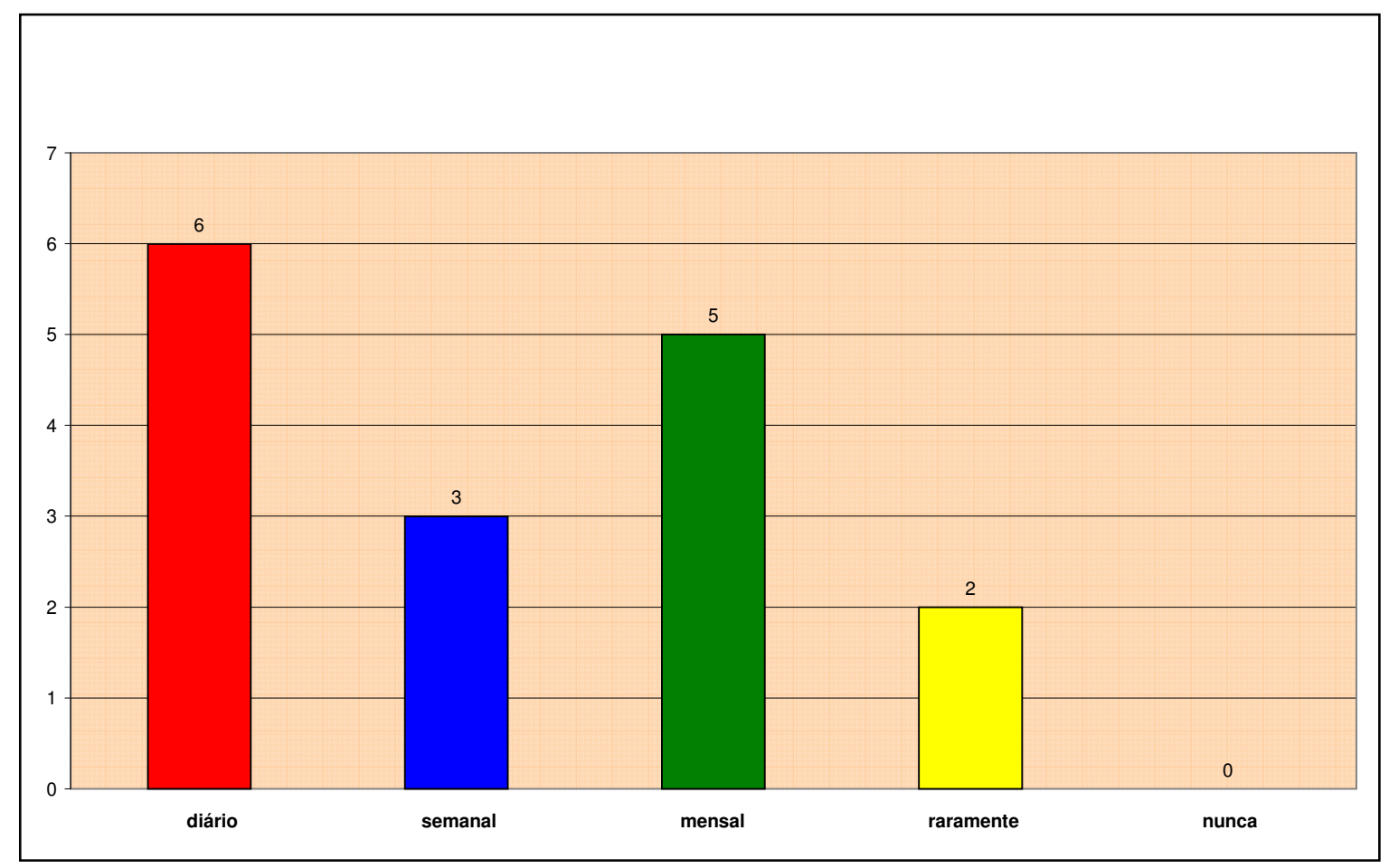

Gráfico 27 - 1a ação do $4^{\circ}$ eixo de Competências do ACS: identificam as condições ambientais e sanitárias que provoquem riscos para a saúde da comunidade.

As condições ambientais e sanitárias que provocam riscos para a saúde da comunidade se diferem nas diferentes micro-áreas e a identificação destas condições depende da observação atenta do ACS. Conforme o gráfico acima, seis (6) ACS revelam que diariamente identificam condições ambientais e sanitárias que provocam riscos para a saúde da comunidade (37,5\%), cinco (5) identificam mensalmente $(31,25 \%)$ e três (3) ACS identificam semanalmente (18,7\%). O percentual dos ACS que raramente identificam estas condições é de 12,5\%, ou seja, dois (2) ACS, revelando que provavelmente, esses dois profissionais não considerem a importância dessa atividade, já que a maioria das micro-áreas apresentam várias situações de risco ambiental e sanitário para a saúde da população local.

A seguir, o gráfico 28 refere-se a segunda ação do quarto eixo de competência do ACS: informa à equipe de saúde sobre a ocorrência de situações de risco, na micro-área de atuação. 


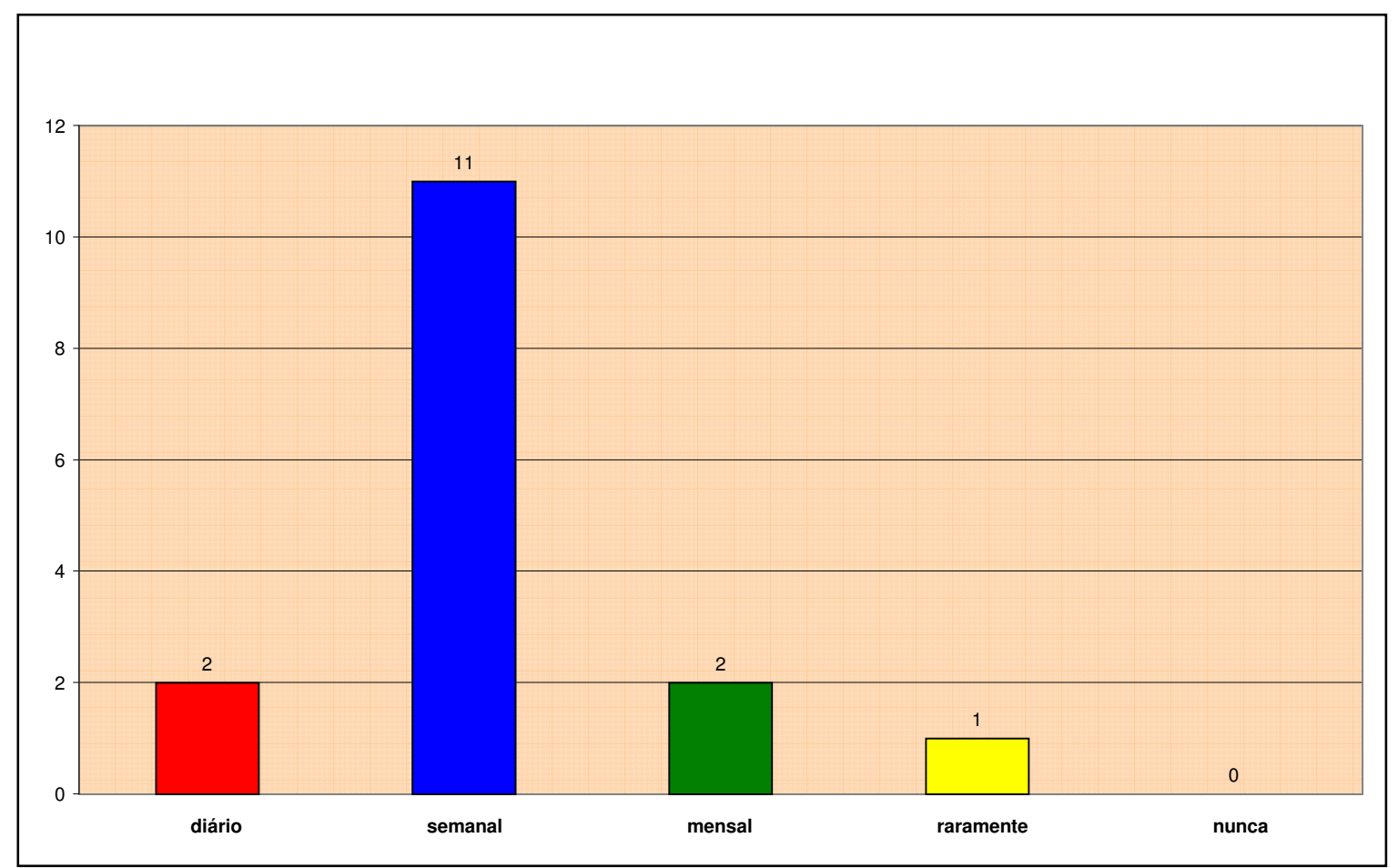

Gráfico 28 - $2^{\mathrm{a}}$ ação do $4^{\circ}$ eixo de competências do ACS: informa à equipe de saúde sobre a ocorrência de situação de risco, na micro-área de atuação.

Informar à equipe sobre as situações de risco ocorridas nas micro-áreas corresponde a uma das primeiras ações na história dos agentes comunitários de saúde. É compreensível que seu maior índice ocorra semanalmente, 68,7\%, ou seja, onze (11) ACS, pois, as reuniões de equipe acontecem uma ou duas vezes por semana e a reunião geral entre as equipes, mensalmente. De maneira reduzida e similar, as freqüências mensal e diária são representadas por dois (2) ACS cada uma $(12,5 \%)$ e um (1) ACS, (6,25\%) relata que raramente realiza esta ação.

O próximo gráfico 29 representa a terceira ação do quarto eixo de competência do ACS: informa à população sobre a ocorrência de situações de risco na micro-área de atuação. 


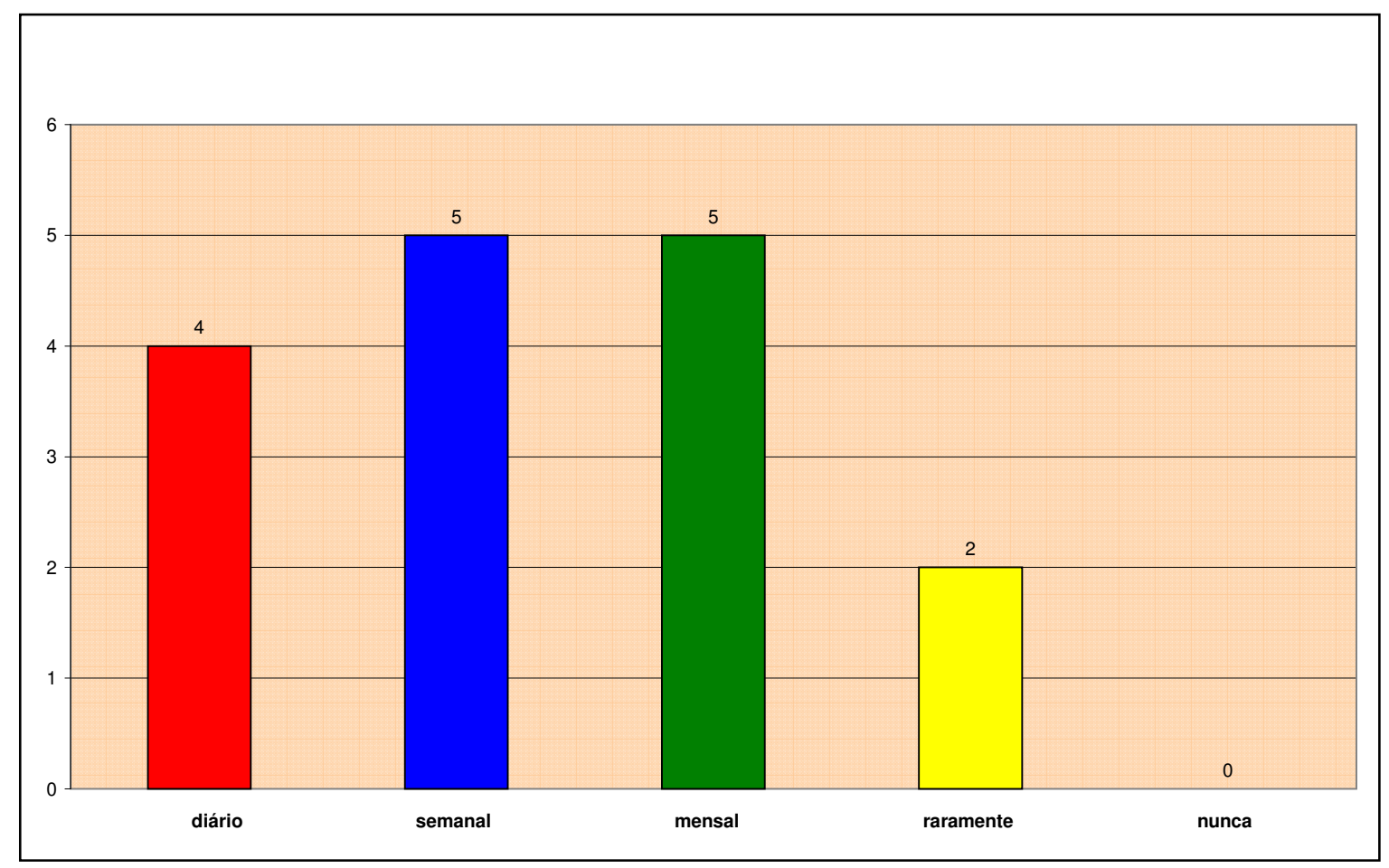

Gráfico 29 - 3a ação do 4ำ eixo de competência do ACS: informa à população sobre a ocorrência de situações de risco, na micro-área de atuação.

Distribuída de maneira quase uniforme, as freqüências diária, semanal e mensal correspondem respectivamente, aos índices de quatro (4) ACS (25\%), cinco (5) ACS (31,2\%) e cinco (5) ACS (31,2\%). Observa-se que não há um padrão para a ocorrência dessa ação, estando presente nas três freqüências, sinalizando que os ACS não receberam a mesma orientação quanto à prática referida. Com certo destaque, nota-se que dois (2) ACS (12,5\%) raramente informam à população sobre a ocorrência de situações de risco em sua micro-área, apontando deficiência na prevenção e monitoramento do risco ambiental e sanitário de sua localidade.

Verifica-se a seguir o gráfico que refere à quarta ação do quarto eixo de competência do ACS: orienta indivíduo e grupos quanto a medidas de redução ou prevenção de riscos ambientais e sanitários em saúde. 


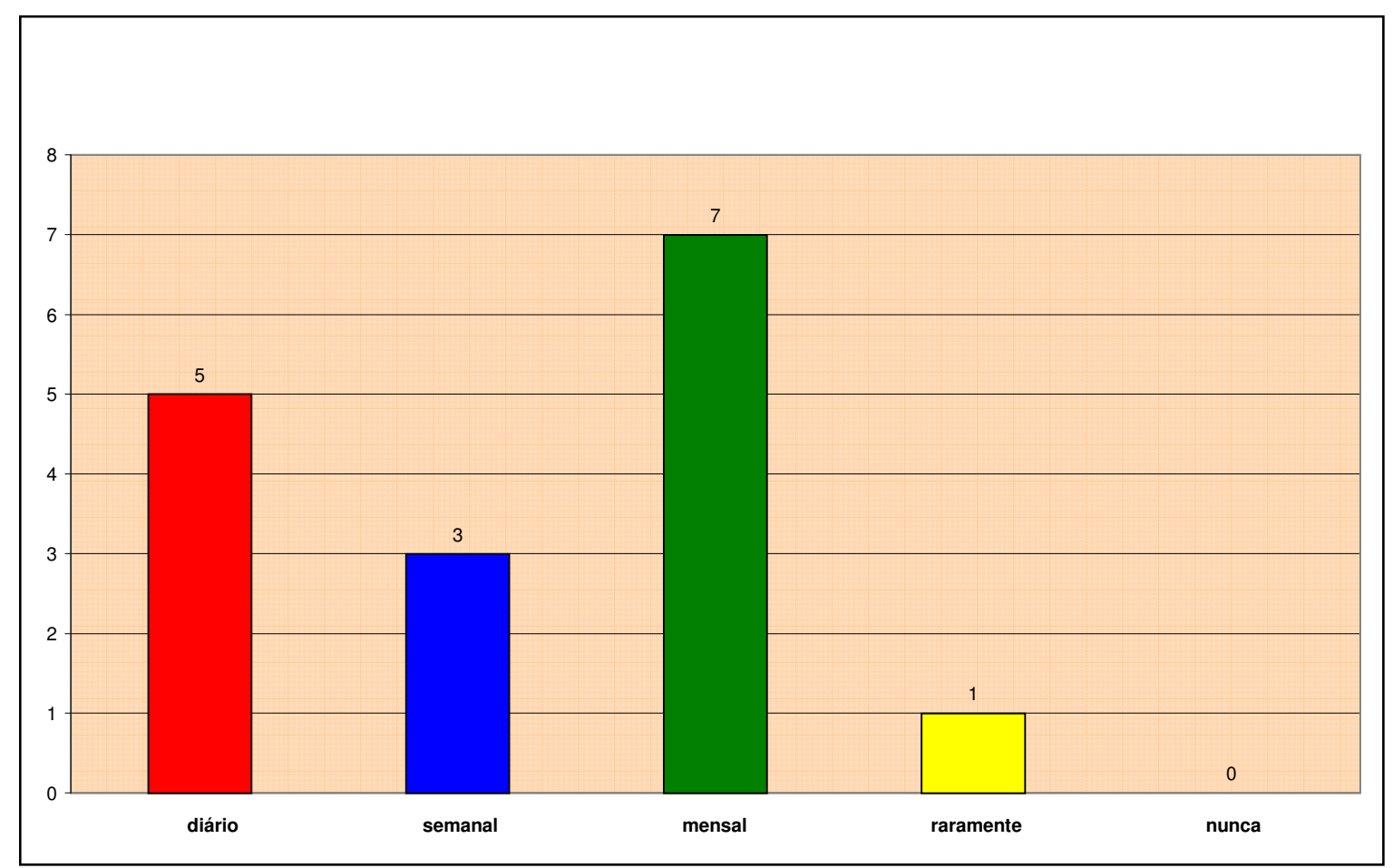

Gráfico 30 - 4⿳亠丷a ação do 4ำ eixo de competências do ACS: orienta indivíduos e grupos quanto a medidas de redução ou prevenção de riscos ambientais e sanitários em saúde.

Orientar quanto a medidas de redução ou prevenção de riscos ambientais e sanitários em saúde requer capacitação dirigida ao tema e observação apurada da situação. O índice mensal desta ação representa sete (7) ACS (43,7\%), o diário, cinco (5) ACS $(31,25 \%)$ e o semanal, três (3) ACS (18,7\%), demonstrando que menos da metade dos profissionais, pelo menos uma vez ao mês, orienta sua população quanto a essas medidas, os demais $50 \%$ se distribuem nas freqüências diária e semanalmente e $6,25 \%$ dos ACS (uma única referência) relata que raramente orienta sobre estas medidas.

O gráfico a seguir refere-se ao conjunto de ações do quinto eixo de competência do ACS: Prevenção e monitoramento a grupos específicos e morbidades. 


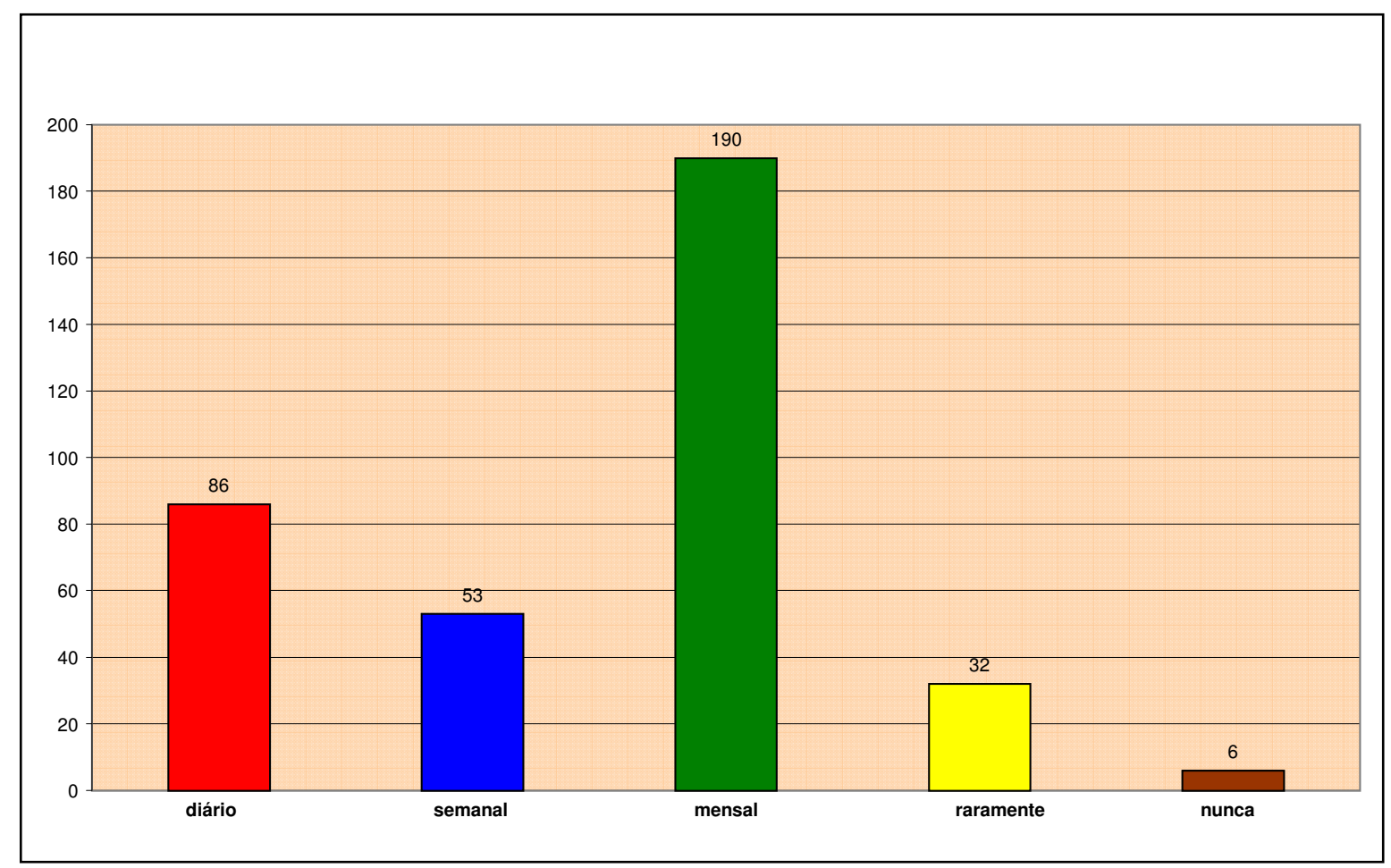

Gráfico 31 - 5o Eixo de Competência do ACS: Prevenção e monitoramento a grupos específicos e morbidades.

Este gráfico 31 reúne vinte e três ações que decodificam a quinta competência do sujeito desta pesquisa. Esta competência descreve ações voltadas à prevenção e acompanhamento dos grupos de prioridade do Programa Saúde da Família. Esses grupos prioritários são constituídos por gestantes, recém-nascidos, crianças menores de dois anos, usuários que apresentam hipertensão, diabetes mellitus, tuberculose e hanseníase. Essas ações englobam ainda a prevenção e acompanhamento de doenças sexualmente transmissíveis, usuários hospitalizados e óbitos, identificados pela a faixa etária e a causa de morte.

A análise do gráfico revela que $51,7 \%$ destas ações são realizadas pelo ACS mensalmente, $14,4 \%$ são realizadas semanalmente, $23,4 \%$ são realizadas diariamente, $8,7 \%$ são raramente realizadas e $1,6 \%$ nunca são realizadas. Revelando, portanto, que a maior parte dessas ações são realizadas mensalmente pelo sujeito desta pesquisa, apontando concordância com o esperado, já que a freqüência das ações de acompanhamento (monitoramento) à grupos específicos é mensal.

A seguir, alguns gráficos específicos do conjunto de ações do quinto eixo de competência do ACS, (prevenção e monitoramento a grupos específicos e 
morbidades) são expostos para uma observação mais detalhada desse conjunto dessas ações.

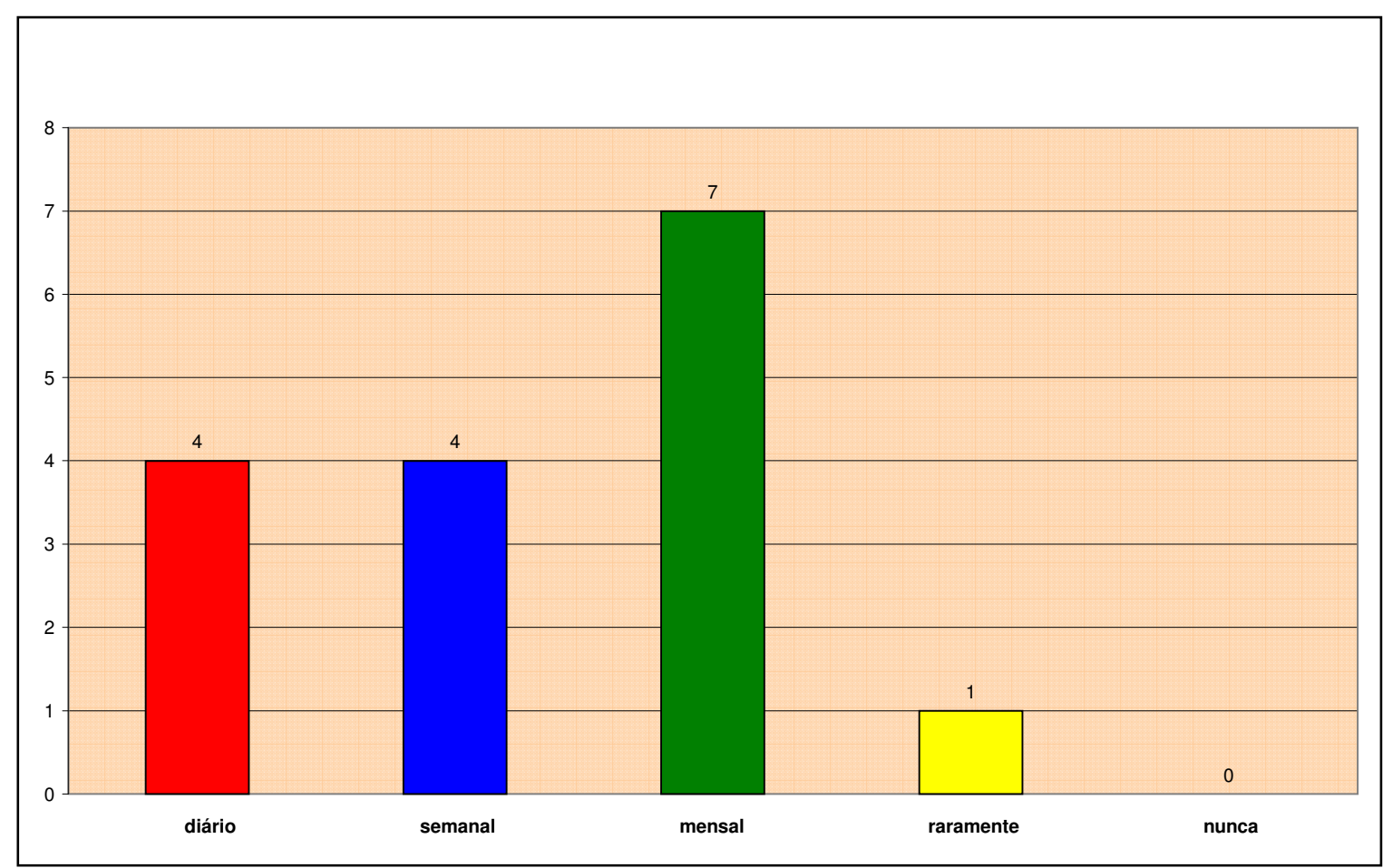

Gráfico 32 - 1a ação do 5o eixo de competências do ACS: identifica indivíduos ou grupos que demandem cuidados especiais de saúde.

Uma das atribuições do ACS é identificar e acompanhar o grupo de prioridade (menor de cinco anos, HA, DIA, TB, etc.). Desta maneira, identificar indivíduos ou grupos que demandem cuidados especiais de saúde, possui conotação acentuada, já que essa ação, que é descrita no banco de dados SIAB, pode ser analisada por várias instâncias: supervisão imediata, coordenação regional, secretaria municipal, estendendo-se até ao governo federal. Espera-se, portanto, que a ação de identificação desse grupo seja realizada diariamente pelo ACS ou no mínimo semanalmente.

No gráfico acima se observam que sete (7) ACS identificam este grupo mensalmente $(43,7 \%)$, quatro (4) semanalmente (25\%), quatro (4) diariamente $(25 \%)$ e um (1) ACS raramente $(6,25 \%)$. Esses dados apontam para uma freqüência aquém do esperado, o que indica que essa ação não está solidificada entre o sujeito pesquisado.

O gráfico a seguir refere-se à segunda ação do quinto eixo de competência do ACS: orienta a comunidade sobre os sinais que indicam problemas de saúde. 


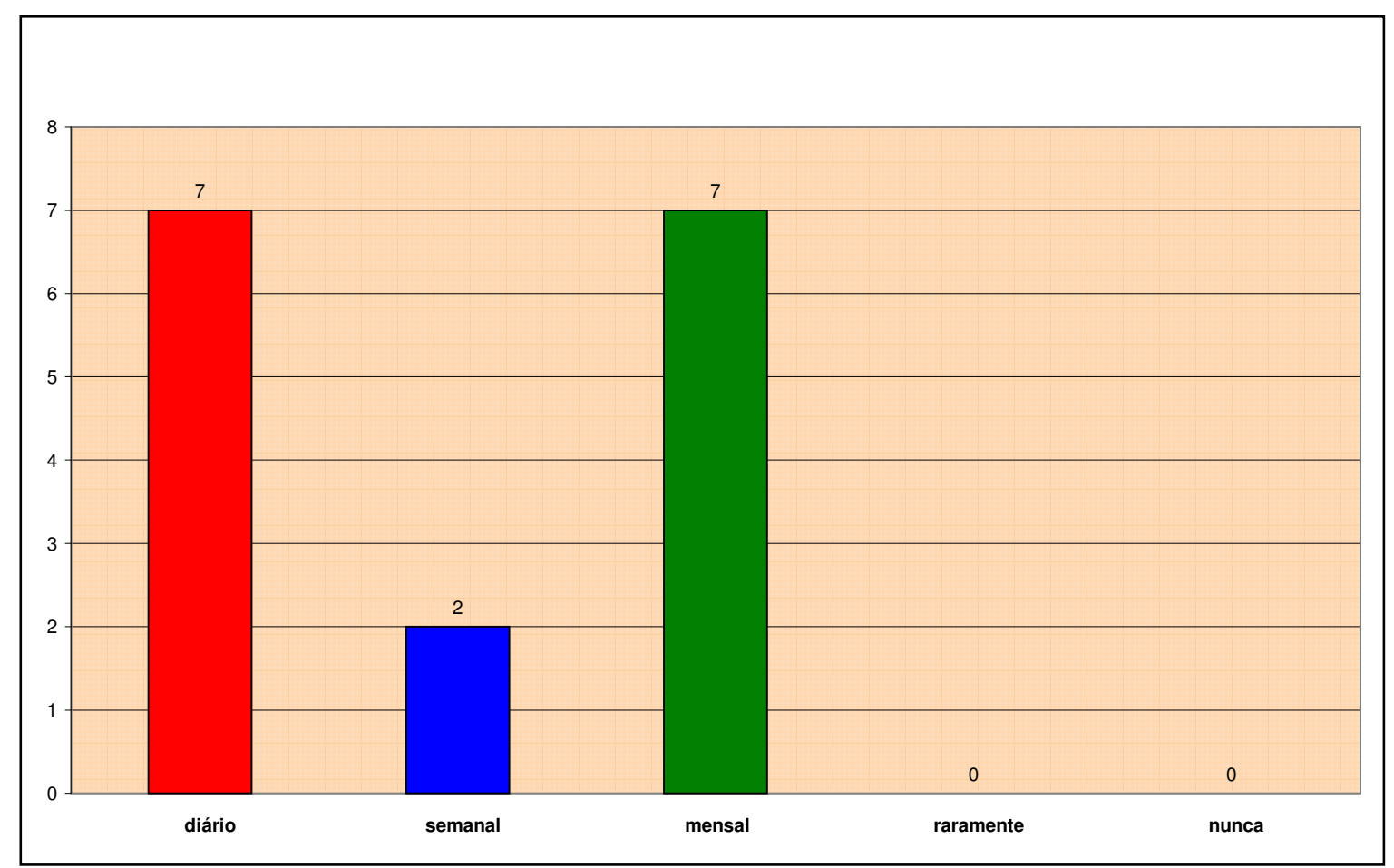

Gráfico 33- 2ª ação do 5 eixo de competências do ACS: orienta a comunidade sobre os sinais que indicam problemas de saúde.

Em relação à ação de orientar a comunidade sobre os sinais que indicam problemas de saúde, o gráfico demonstra que sete (7) ACS (43,7\%) apresentam freqüência diária, sete (7), freqüência mensal (43,6\%) e dois (2) ACS freqüência semanal (12,5\%). É possível inferir, considerando a importância dessa ação, que o ACS investigado não incorpora no cotidiano de seu trabalho, a orientação à comunidade sobre os sinais que indicam problemas de saúde.

O gráfico a seguir refere-se à terceira ação do quinto eixo de competência do ACS: comunica a equipe sobre os casos existentes de indivíduos ou grupos que necessitem de cuidados especiais ("grupos de risco", portadores de necessidades especiais e outros). 


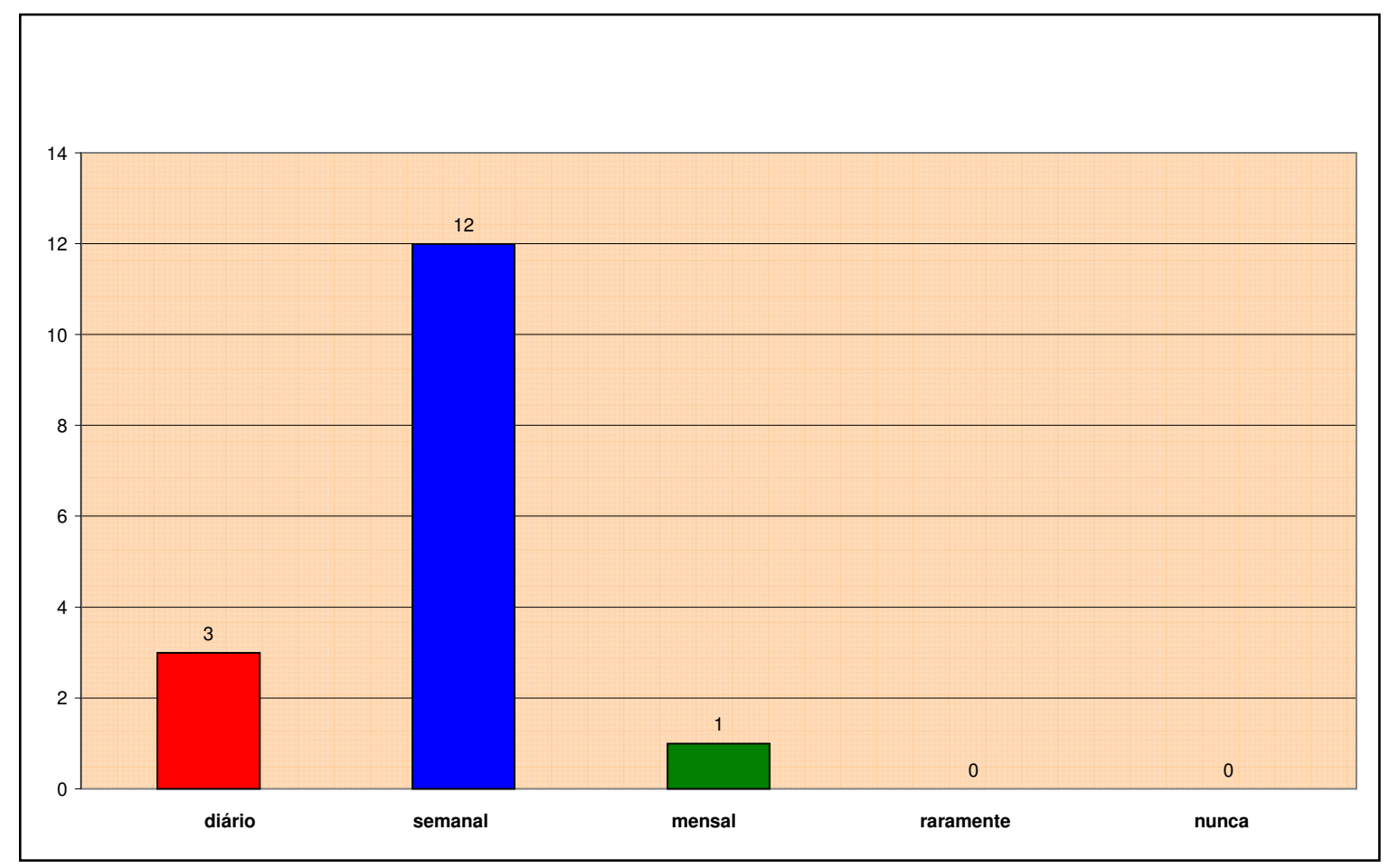

Gráfico 34 - 3a ação do 5 eixo de competências do ACS: comunica à equipe sobre os casos existentes de indivíduos ou grupos que necessitam de cuidados especiais ("grupos de risco", portadores de necessidades especiais e outros).

O meio de comunicação mais freqüentes entre o ACS e a equipe é a reunião de equipe, que acontece semanalmente entre as distintas equipes, e 0 encontro mensal entre as três equipes de PSF estudadas. A partir desse dado é possível observar que doze (12) dos entrevistados relatam que, semanalmente realizam essa ação (75\%), três (3) ACS diariamente (18,75\%) e um (1) ACS mensalmente (6,25\%). Esse relato aponta para uma ação frequentemente realizada pelo ACS.

Verifica-se no próximo gráfico, a quarta ação do quinto eixo de competência do ACS: ao identificar um problema de saúde nos indivíduos ou grupos, encaminha à UBS para atendimento. 


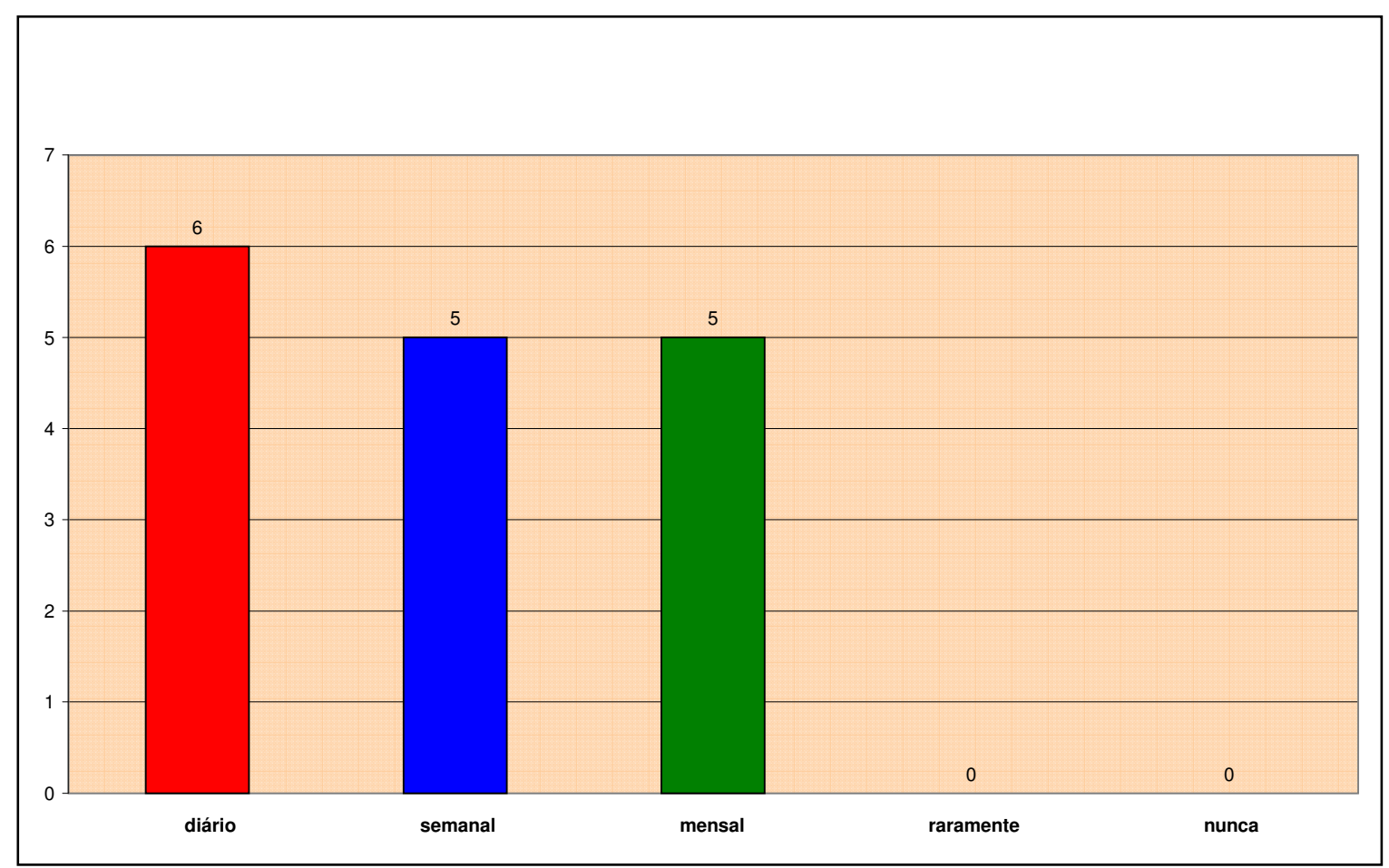

Gráfico 35 - 4a ação do 5e eixo de competências do ACS: ao identificar um problema de saúde nos indivíduos ou grupos, encaminha à UBS para atendimento.

A demonstra que seis (6) dos profissionais entrevistados encaminham, diariamente, problemas de saúde individual ou grupal, para atendimento na Unidade Básica de Saúde (37,5\%). Cinco (5) ACS relatam que semanalmente realizam essa ação $(31,25 \%)$ e seis (6) mensalmente o fazem (31,25\%). A distribuição equilibrada entre as freqüências diária, semanal e mensal, revela que, de acordo com a demanda, os encaminhamentos à UBS são realizados frequentemente.

O gráfico a seguir refere-se à quinta ação do quinto eixo de competência do ACS: agenda ou remarca consultas para a comunidade. 


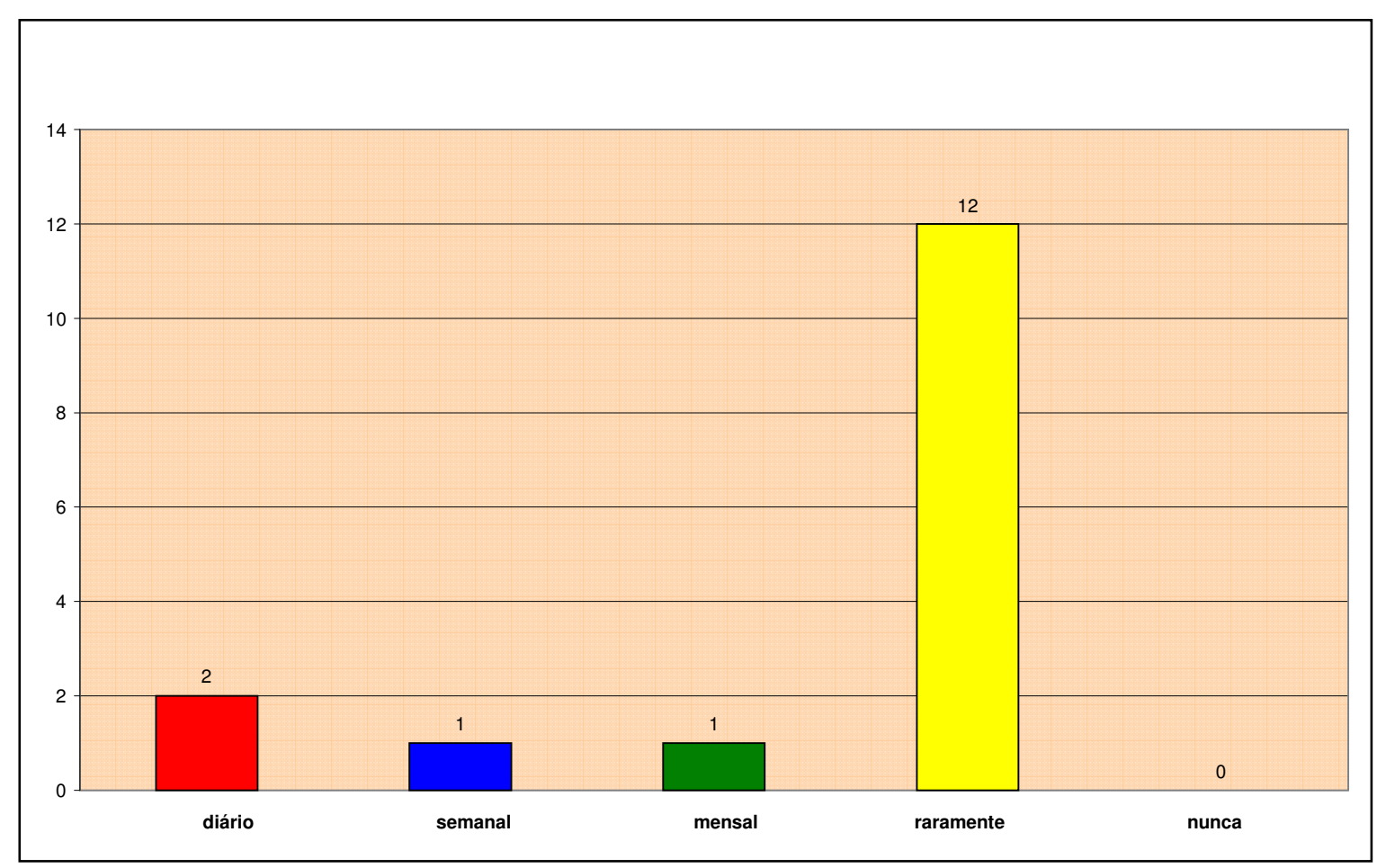

Gráfico 36 - 5a ação do 5 eixo de competência do ACS: agenda ou remarca consultas para a comunidade.

O agendamento de consulta pelo ACS é palco para diversas discussões entre vários pontos de vista, podendo, em determinadas situações, gerar ação assistencialista à população, dificultando o desenvolvimento da participação coletiva e individual, no levantamento das suas necessidades de saúde (empowerment). Por sua vez, essa ação pode ser fundamental para que grupos de atendimento prioritário (gestantes, crianças menores de dois anos, HA, DIA, TB e HAN.) tenham garantia de atendimento, prevenindo e monitorando as morbidades.

Por meio da análise do gráfico anterior, é possível constatar que doze (12) dos profissionais pesquisados, relatam que raramente realizam essa ação (75\%), dois (2) ACS indicam freqüência diária (12,5\%), um (1) ACS freqüência semanal $(6,25 \%)$ e um (1) ACS freqüência mensal (6,25\%). Observa-se que a maioria desses profissionais raramente agendam consultas na Unidade Básica de Saúde.

O gráfico a seguir refere-se à sexta ação do quinto eixo de competência do ACS: leva medicação (conforme prescrição médica ou de enfermagem) para alguém da população. 


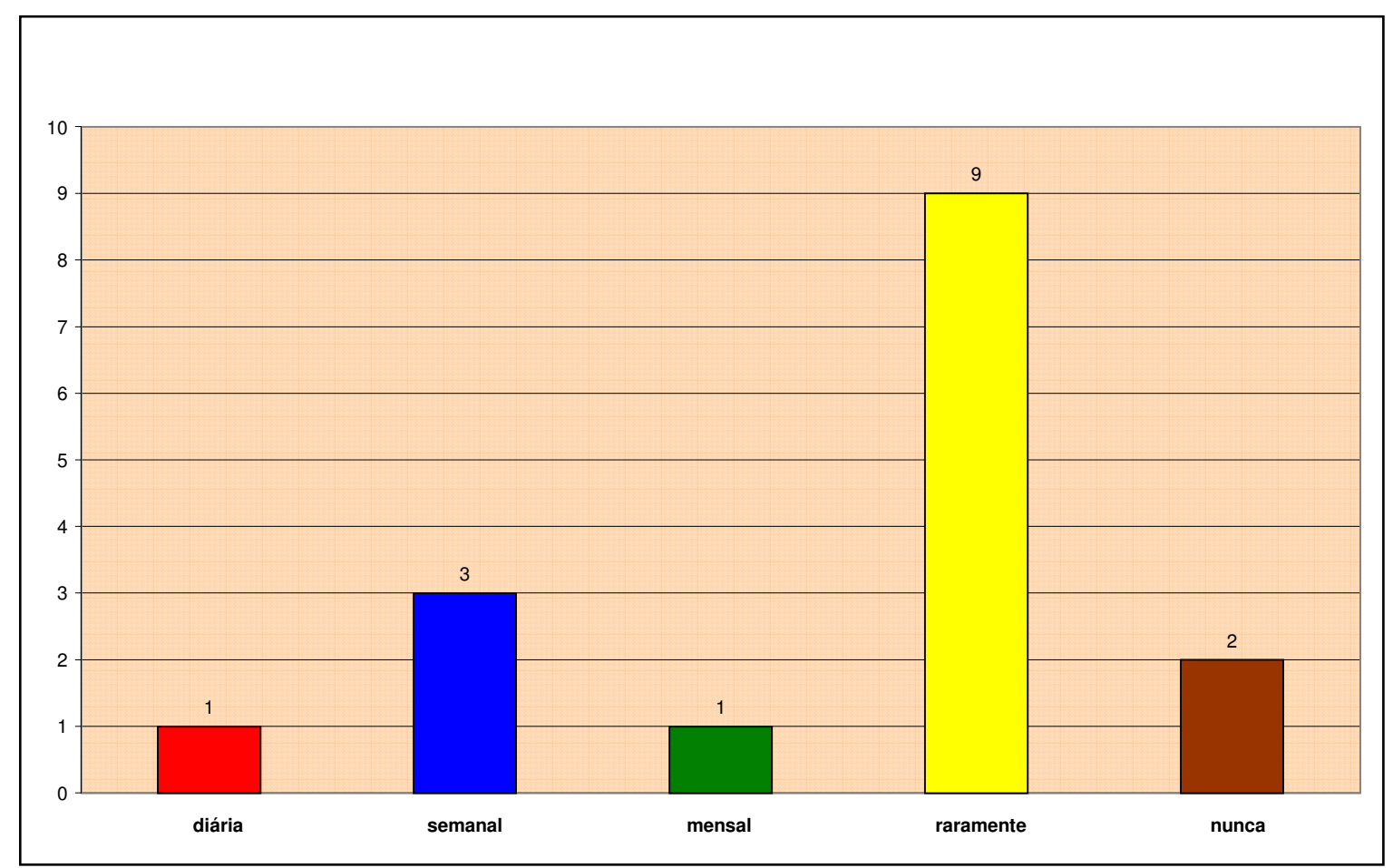

Gráfico 37 - 6a ação do 5ำ eixo de competência do ACS: leva medicação (conforme prescrição médica ou de enfermagem) para alguém da população.

No seguimento do mesmo processo de análise do gráfico anterior é possível observar que nove (9) ACS investigados raramente levam medicamentos para alguém da população (56,25\%). Três (3) ACS semanalmente realizam essa ação (18,75\%), dois (2) ACS nunca realizam (12,5\%,) e um (1) ACS realiza diária e mensalmente. Esses dados revelam um alto índice de ACS que raramente praticam essa ação (56,25\%), incluindo aqueles que nunca a realizam (6,25\%). Uma das justificativas para essa constatação pode ser a curta distância entre a UBS e os domicílios, considerando que as moradias coletivas (prédios e cortiços) concentram um maior número de pessoas em um menor espaço horizontal. Outro argumento poderia ser o programa municipal (remédio em casa), que entrega o medicamento em domicílio, pelo correio.

O gráfico a seguir refere-se à sétima ação do quinto eixo de competência do ACS: sensibiliza os familiares e seu grupo social para a convivência com os indivíduos que necessitam de cuidados especiais. 


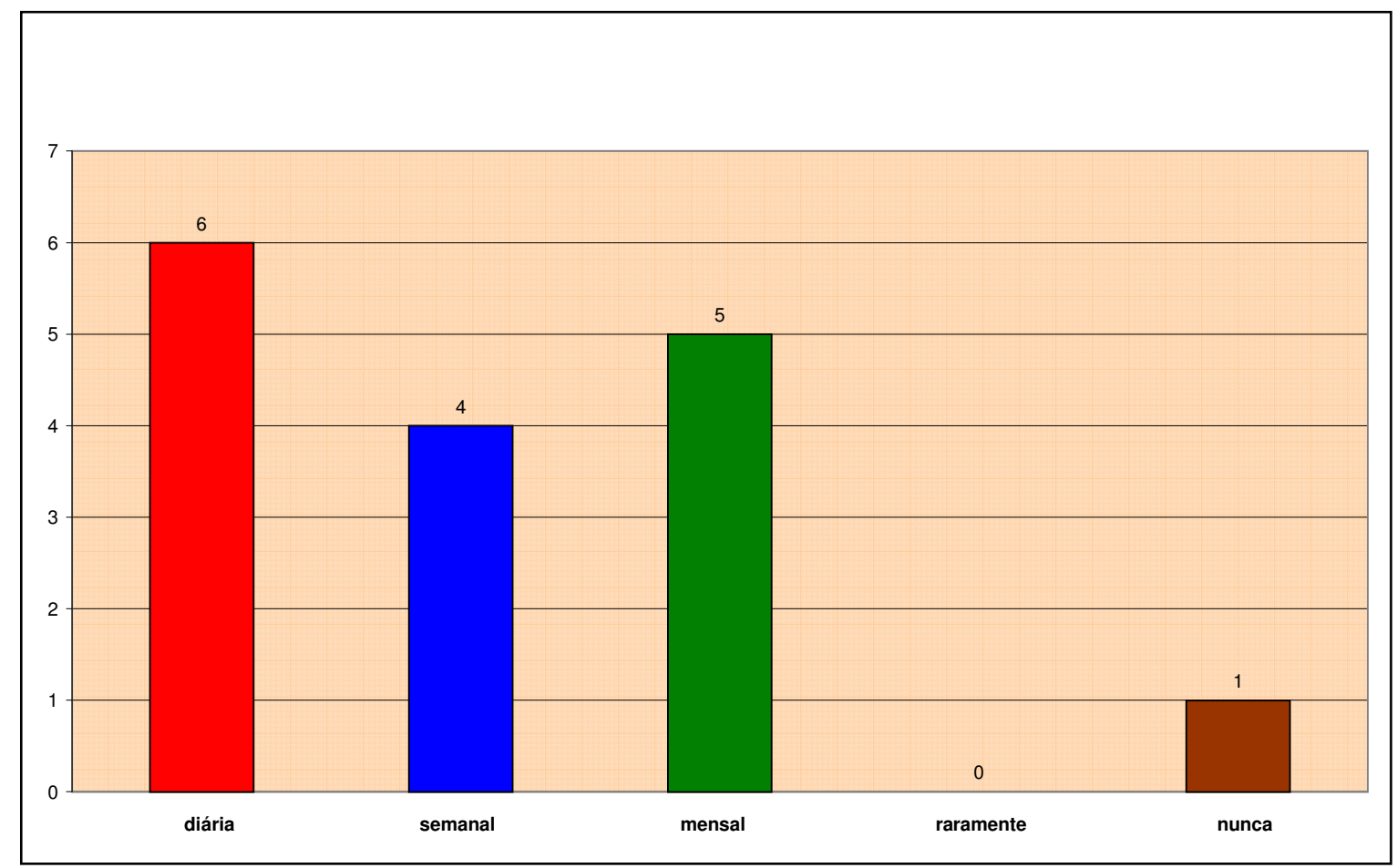

Gráfico 38 - 7ª ação do 5o eixo de competências do ACS: sensibiliza os familiares e seu grupo social para a convivência com os indivíduos que necessitem de cuidados especiais.

A presença de pessoas com necessidades especiais muitas vezes podem gerar situações de negligência no cuidado por parte de algumas famílias. O diálogo aberto entre o ACS e as famílias sobre essa situação pode sensibilizar os familiares ou o grupo social em questão, fazendo com que as situações de negligência diminuam.

Diante dessa questão, observa-se no gráfico que seis (6) ACS, relatam realizar essa ação diariamente (37,5\%), cinco (5) realizam mensalmente (31.25\%), quatro (4) ACS semanalmente (25\%) e um (1) diz que nunca a realiza (6,25\%).

Verifica-se a seguir o gráfico que refere-se à oitava ação do quinto eixo de competência do ACS: estimula indivíduos, familiares e grupos a participarem de programas sociais locais que envolvam orientação e prevenção da violência intrafamiliar. 


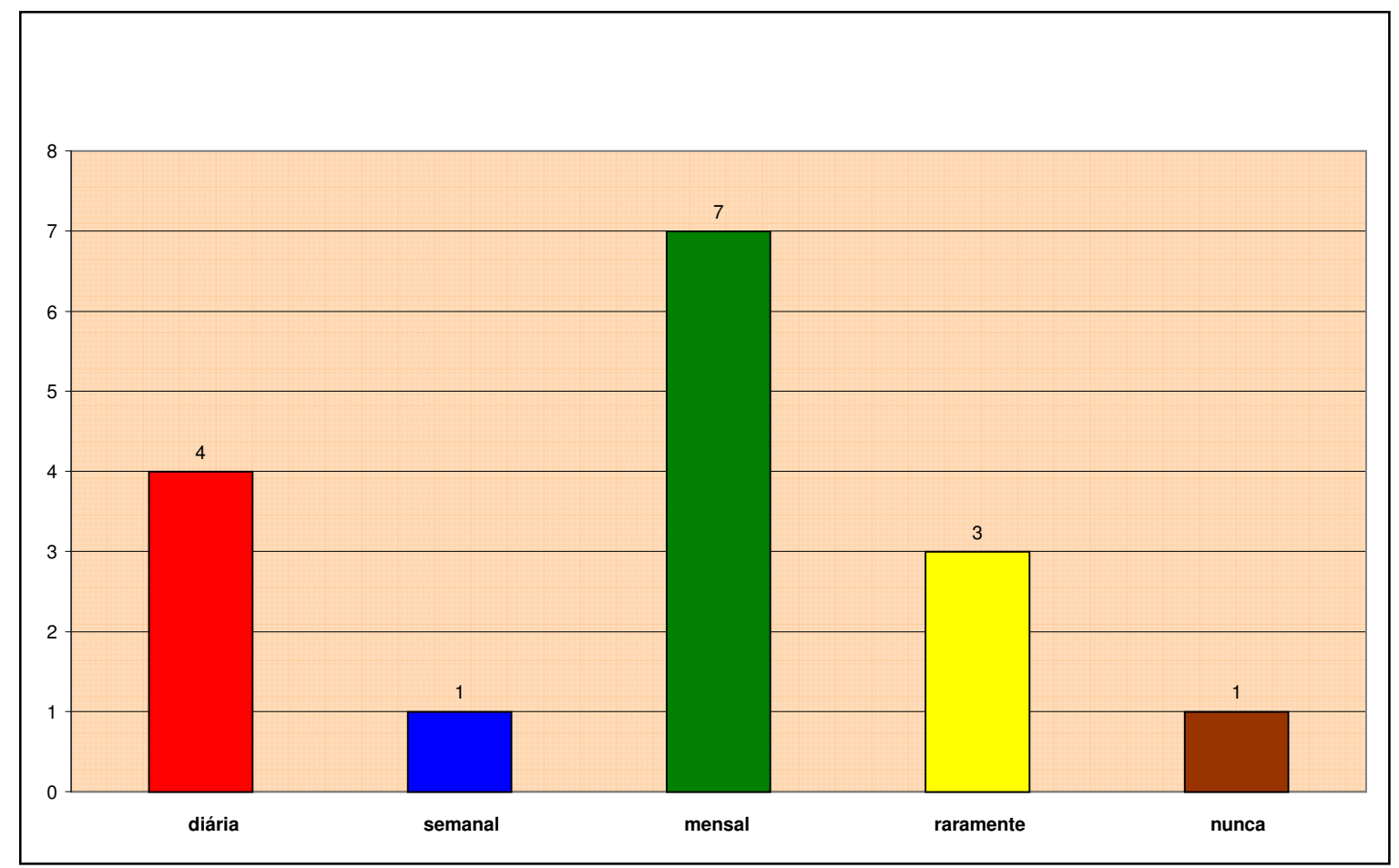

Gráfico 39 - 8ª ação do 5 eixo de competências do ACS: estimula indivíduos, familiares e grupos a participarem de programas sociais locais que envolvam orientação e prevenção da violência intra e inter-familiar.

O fato de que sete (7) ACS, mensalmente, estimulem a comunidade a participar de Programas contra a Violência, pode indicar falta de preocupação, por parte desse profissional, com essa questão. Isso pode ser corroborado se observarmos que quatro (4) desses profissionais indicam realizar essa ação diariamente (25\%), três (3) ACS raramente (18,75\%), um (1) semanalmente $(6,25 \%)$ e um (1) ACS nunca a realiza (6,25\%). É possível interpretar que esse assunto, provavelmente, não seja debatido com a freqüência para, a partir dessa reflexão, transformar-se em uma ação cotidiana.

O próximo e último gráfico refere-se à nona ação do quinto eixo de competência do ACS: orienta as gestantes sobre os cuidados relativos à gestação. 


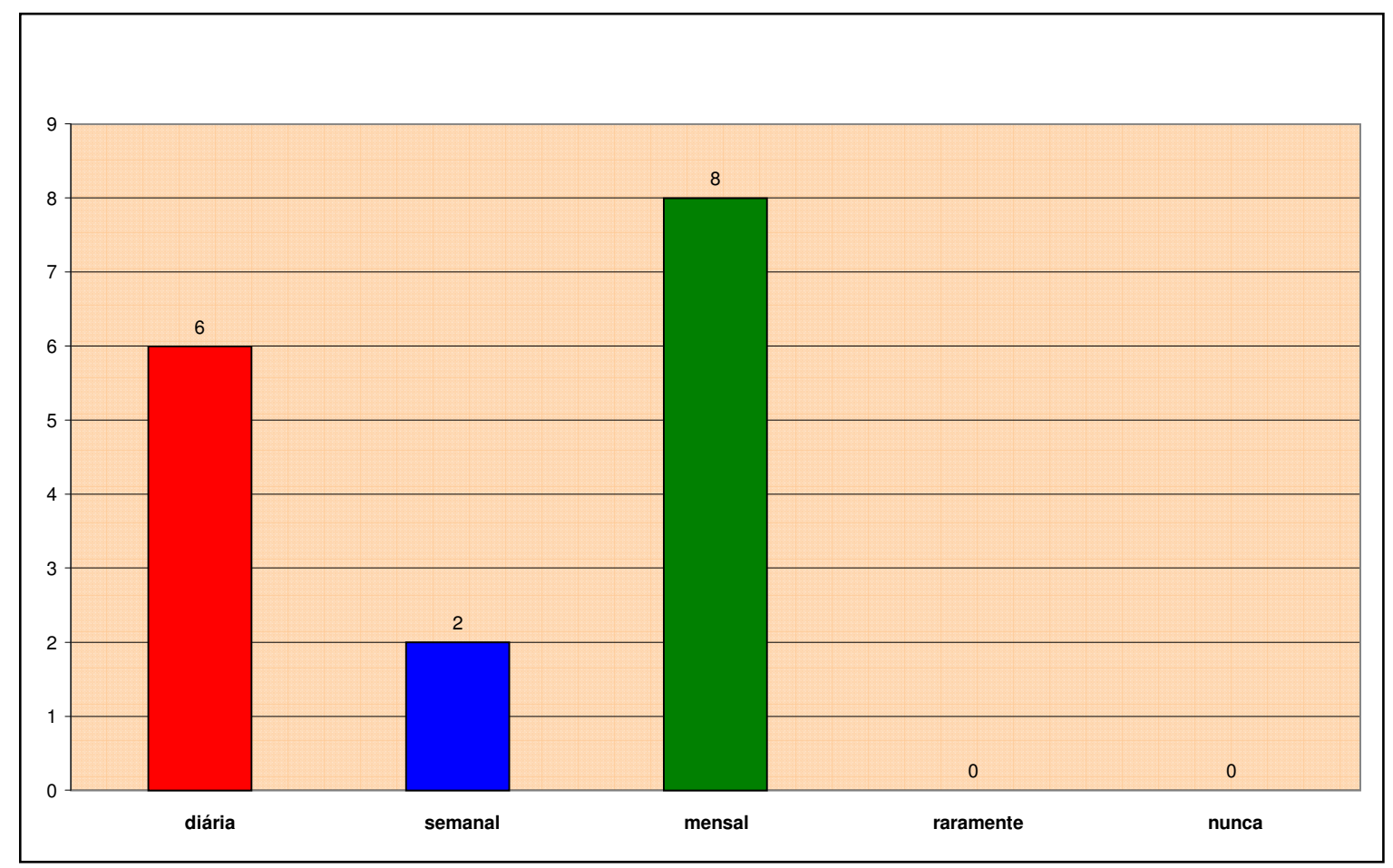

Gráfico 40 - 9a ação do 5 o eixo de competências do ACS: orienta as gestantes sobre os cuidados relativos à gestação.

As ações que visam ao cuidado da gestante estão presentes desde os primórdios do trabalho do ACS, mesmo antes de se tornar um programa com dimensões nacionais. A transformação do trabalho do ACS em freqüências diária, semanal, mensal, raramente e nunca, pode ter dificultado, em particular, a explanação dessa ação, pois, operacionalmente, o ACS deve visitar e acompanhar todas as gestantes mensalmente, usando este momento para também orientá-la quanto aos cuidados à gestação. Ao transformar esta ação em freqüência é possível que o ACS tenha indicado a referência mensal pela similaridade operacional com o seu trabalho, que é mensal, podendo então justificar uma freqüência aquém da esperada. O gráfico apresenta que oito (8) dos entrevistados, realizam essa ação mensalmente (50\%), seis (6) ACS diariamente (37,5\%) e dois (2) ACS semanalmente $(12,5 \%)$.

O quadro a seguir aponta para o índice de cada conjunto de ações das cinco competências do ACS, indicando, quantitativamente, qual conjunto de ação é mais freqüente no seu cotidiano: 
Quadro 1 - Análise quantitativa das ações presentes entre os cinco eixos de competências do ACS

\begin{tabular}{|l|}
\hline ESTATISTICAMENTE, AS AÇÕES INDICADAS PELO ACS ESTÃO \\
DISTRIBUIDAS ESTRE AS CINCO COMPETÊNCIAS DA SEGUINTE \\
FORMA: \\
\hline 1- 92,5\% DAS AÇÕES DE INTEGRAÇÃO DA EQUIPE COM A POPULAÇÃO \\
LOCAL SÃO INDICADAS PELO ACS. \\
2- 89,5\% DAS AÇÕES DE PREVENÇÃO E MONITORAMENTO A GRUPOS \\
ESPECÍFICOS E MORBIDADES SÃO INDICADAS PELO ACS. \\
3- 82,5\% DAS AÇÕES DE PREVENÇÃO E MONITORAMENTO DO RISCO \\
AMBIENTAL E SANITÁRIO SÃO INDICADAS PELO ACS. \\
4- 78,7\% DAS AÇÕES DE PLANEJAMENTO E AVALIAÇÃO SÃO INDICADAS \\
PELO ACS. \\
\hline 5- 65,5\% DAS AÇÕES DE PROMOÇÃO DA SAÚDE SÃO INDICADAS PELO \\
ACS.
\end{tabular}

Esta análise baseia-se na somatória das freqüências diária, semanal e mensal do conjunto de ações dos cinco eixos de competência do ACS, transformando esse resultado em porcentagem para que, por meio da concentração destes dados, tornese possível uma análise geral quantitativa entre esses eixos.

É possível observar que, proporcionalmente, as ações de promoção da saúde, são indicadas com menor proporção quantitativa pelos sujeitos investigados, identificando $65,5 \%$ destas ações realizadas pelo ACS, distribuídas entre as freqüências diária, semanal e mensal. Torna-se óbvio declarar que as ações de promoção da saúde, decodificadas no instrumento de coleta de dados desta pesquisa, ainda não estão integralmente familiarizadas entre os ACS, evidenciando uma necessária investigação qualitativa desse fenômeno.

De acordo com a quinta competência proposta pelo MS, "Desenvolver ações de prevenção e monitoramento à grupos específicos e morbidades, definida no plano de ações das equipes de saúde, dirigidas a grupos específicos e a doenças prevalentes conforme protocolos de saúde pública" ${ }^{(14)}$, entre os conhecimentos necessários para o desenvolvimento das habilidades relativas a esta competência estão:

[...] "conhecer as estruturas e funcionamento do corpo humano, cuidados gerais com o recém-nascido, aleitamento materno (anatomia e fisiologia da mama) e cuidados gerais com a mama, conceito, sinais e sintomas e fatores de risco das doenças crônicas-degenerativa" $[\ldots]^{(14)}$, entre outras. 
Baseado nesse fato, espera-se que o ACS esteja basicamente preparado com informações técnicas de saúde, de forma a subsidiá-lo diante de situações em que o monitoramento de doenças ou agravos, ou mesmo a orientação de determinados hábitos saudáveis faça-se necessário.

Corre-se o risco, então, do ACS se não for bem capacitado e não delinear sua atuação perante a comunidade, se tornar um pseudo-profissional de saúde, acumulando características próprias dos técnicos do setor da saúde, desviando de seu enfoque principal, que são as ações de promoção da saúde.

$\mathrm{Na}$ amostra dos sujeitos desta pesquisa, pôde-se observar que um grupo reduzido, mas, considerável de ACS, possuíam formação profissional em auxiliar de enfermagem.

Essa situação, a meu ver, pode dificultar que este profissional, venha compreender qual é o seu papel e desempenho, em relação às reais competências de sua profissão e na construção de seu trabalho mais próximo das necessidades e do empowerment da comunidade.

\subsection{AS PERCEPÇÕES DOS ACS SOBRE SUAS AÇÕES DE PROMOÇÃO DA SAÚDE}

Nesta análise reuniram-se os depoimentos relatados na transcrição do grupo focal, realizado com dez ACS. Após a apresentação dos gráficos que, representaram o consolidado das respostas ao formulário de atividades do ACS (Anexo I), iniciou-se a discussão no grupo focal onde, intencionou-se, explorar a concepção dos ACS, sobre as ações e conceitos de promoção da saúde.

Após a leitura com exaustão, suficiente para esgotar as possibilidades de encontrar as expressões chaves, compatíveis com as idéias centrais e ou ancoragens dos determinados depoimentos, Identificaram-se discursos dispostos em três grandes Idéias Centrais (IC), a primeira IC identificada refere-se ao "trabalho do ACS", a segunda IC refere-se ao "desenvolvimento de atividades inter-setoriais na comunidade para o ACS" e a terceira IC refere-se a "valorização das ações do ACS pela Comunidade". 
Dentro da Idéia Central (IC) "O trabalho do ACS no PSF" pode-se identificar o surgimento de três diferentes temas, um relativo a "dificuldade em quantificar seu trabalho", o outro relacionado a "atividade cotidiana do ACS" e um terceiro tema discutindo a "Prevenção e a promoção na prática do ACS".

Os discursos ficaram organizados da seguinte maneira:

\author{
IC 1 : O trabalho do ACS
}

Tema A: Dificuldade em quantificar seu trabalho

-Eu senti que no questionário tinham respostas que eu não sabia se marcava mensal ou diário, o meu trabalho é fazer a visita uma vez por mês em uma casa, mas, eu faço visitas todos os dias para várias famílias. Tem Família que eu vou uma, duas vezes na mesma semana, depende da situação, por exemplo, remédio, pra algumas pessoas eu levo, pra quem não consegui, é por mês. As questões sobre identificar problemas, promoção da saúde e a relação entre a equipe e a população, isso é todo dia. Houve resposta que eu coloquei até dois X's, algumas coisas ficaram meio duvidosas. Cada dia eu vou em uma casa diferente. Pensar, eu vou na casa da E. é mensal, mas, faço visita todos os dias para várias famílias. Quando é prioridade eu vou varias vezes e, sempre tem uma dúvida e, eu sempre dou uma resposta. Tem um problema eu vou, eu fico preocupada e vou. Algumas perguntas eu achei confuso e eu perguntava aos colegas, uma ajudava a outra. Orientar o indivíduo quanto ao auto cuidado, são atividades diárias, eu faço uma vez por mês para determinada família e outras, todos os dias. Acho que a maioria é diária. Raramente não quer dizer nunca, não vejo raramente no meu trabalho. Meu trabalho é feito diariamente, raramente quase não se aplica. Raramente se aplica para, secretaria e o uso de instrumentos, quando tem alguma campanha. Quem colocou (raramente), não entendeu direito. Uma pessoa só, não é atividade educativa, eu entendi como grupo e, coloquei mensalmente. Eu acho que a pergunta confundiu um pouco $\mathrm{Na}$ comunidade eu vou sozinha e, faço uma visita educativa sozinha. Então, é diariamente. Eu já fiz sozinha, já fiz acompanhada. Tem muita gente que nunca fez sozinha.

Tema b) A atividade cotidiana do ACS

-Moro na rua. Tem panfletos não é? As vezes tiram as dúvidas. Eu aprendo na capacitação e o panfleto é um reforço né? Gosto dos panfletos. $\mathrm{Na}$ visita, deixo com a pessoa (cadastrado), porque naquele momento ela não assimilou, está te ouvindo, mas não está ai, mas, amanhã ou depois ela vai pegar alguma coisa e o panfletinho está lá sobre a amamentação, deixa eu dar uma olhada... como é mesmo para colocar o neném?. Eu tenho várias capacitações e, no entanto haviam dúvidas. O folheto é bom, pois quem tem alguma dúvida, procura lá. É como a E. falou, deixo guardadinho, deixo na bolsa, pois guardar tudo de cabeça... Acha que sabemos tudo! Eu falo: não sei. No meu trabalho, um exemplo positivo é o Papanicolau (exame preventivo do câncer de colo uterino). Eu oriento, faço meu trabalho direitinho e estou colhendo os frutos. Identificar bastante e curar as pessoas, pra mim, isso é evento positivo. Infelizmente tenho na minha micro-área muitos 
alcoólatras. Eu consegui que três parassem de beber, graças as broncas e orientações. Vai enfermeiro, médico, até minha irmã vai junto (a irmã é ACS), graças ao que a gente passa, eles pararam. Acho que é um dado positivo. Eu consigo ver a pessoa conscientizada, tentando mudar seus hábitos de exercício, alimentação, etc. Fico convencida. Tive um caso de uma mãe que não queria levar a criança pra APAE. Encontrei com a irmã dela e ela está levando. É conquista! Na minha área não tinha PSF, eu comecei nesse trabalho e eles achavam que não tinham direito à prevenção, só quando estão doentes. Fiz todo um trabalho em cima disso. Ontem mesmo eu estava num aniversário e uma falou pra outra: Olha, isso não pode comer. Ali eu vejo meu trabalho. Pra chegar é trabalhoso, é conquistado. As pessoas acham que não tem direito, não tem condições. Eu falo, tem direito ao papanicolaou, exames de sangue. O PSF é muito importante.-Eu chego em uma casa e, dá pra saber, aqui vou ter problema.

\section{Tema c) Prevenção e promoção na prática do ACS.}

--Eu sonho com a prevenção, faz parte de mim, eu respiro isso. Levanto da cama e estou preocupada com isso. A semana inteira faço promoção da saúde, todos os dias, inclusive, até mesmo quando estou em minha casa. Fico meio possuída pelo trabalho. Não só em casa, na rua também. De repente, naquela semana eu cadastro duas famílias, eu faço promoção da saúde duas vezes, eu explico como funciona o programa. No meu cadastro eu falo, é melhor prevenir, que ir para o hospital ficar acamado. Dá muito mais despesa para o Estado assim. Tem pessoas que não querem aceitar a doença, a rebeldia, ou o fato de ter de cuidar. Além de ter problemas de saúde ainda tem que cuidar de outros que tem doença! Eu encontro muitos casos parecidos. Por mais que eu oriente, mais que eu faça planejamento, eu me decepciono. Eu faço a minha parte, mas, não posso obrigar o outro a fazer o que eu oriento. É um trabalho árduo. Tem família que eu vou duas, três vezes e ela não se conscientiza. Cada família é um olhar diferente. Outras eu tenho de falar todo mês e outras eu falo uma vez só, pega no ar. As vezes me encontra na rua e, eu não tenho como dizer não, vou ter que dar orientação. É trabalhoso, é complicado. Por mais que eu queira ajudar, no meu trabalho, eu não obtenho cem por cento. Eu faço a minha parte e vou embora, mas, pra ele o dia a dia é complicado. Eu vejo, pelo lado mais negativo.

IC-2: O desenvolvimento de atividades inter-setorias na comunidade para o ACS.

-Eu coloquei raramente para a participação no Conselho local de saúde. Eu ia todos os meses, poucas pessoas iam, a diretora, (...) e nós (os ACS), eu ficava até meia-noite lá. Chegou uma hora que eu falei: eu não vou mais. Se não é obrigatório, eu não vou. Se fosse uma coisa boa para todos, porque não estavam ali. Por isso eu coloquei raramente. Se houvesse necessidade e dissessem para mim vá e, todos fossem, eu iria. Mas quase ninguém vai, nada era resolvido. Minha área tem muitas pessoas que não sabem ler nem escrever. Tem a Achiripita e o CJ (Instituições de auxilio à alfabetização), então eu peço para procurar um dos dois. Entendi que, incentivar meu 
cadastrado a procurar um lugar para se alfabetizar, é um apoio social. Eu dou um conselho, eu mostro, mas, se a pessoa vai eu não sei. Um cadastrado adulto que não é alfabetizado eu dou um toque, dou a maior força, alguns trazem o caderno para mostras as letras. Chego numa casa que têm seis crianças, uma não está na escola, a ação educativa eu falo pra mãe: tem que colocar este menino na escola, você está prejudicando o desenvolvimento da criança. Ela fala "ah! não sei aonde vai", vai procurar uma assistente social. Uma criança, por exemplo, não estava nem registrada na escola, tem nove anos, eu falo, vai procurar! A mãe fala, "já procurei". Então vai procurar outra forma. Eu as vezes incluo crianças, adolescente e fica um outro ai com doze anos, falei, vai procurar a assistente social. Oriento também, famílias que tem filhos com quatorze, dezesseis anos que ficam o dia todo dentro do quarto, para fazer um curso profissionalizante. $O$ bairro tem bastante disso. De repente aparecem cinco cadastros novos naquela semana e, em uma família tem um pai ou um tio que, não está estudando. Então naquele mês eu faço mais (apoio), pois, é cadastro novo. Agora, as famílias que eu já tenho cadastrado, algumas já correram atrás e outras não, por motivo de filho, trabalho, etc. Eu oriento também o lazer. Como moro no bairro, sei o lugar que podem ir. Algumas (famílias) já conseguiram colocar o filho para fazer natação. Eu mostro, vai quem quer, o interesse é da pessoa. Tem crianças que ficam com as avós, não tem lazer nem atividade. Eu oriento que a creche é um lugar bom. Eu coloquei raramente para a atividade de "executar ações que atuam em parceria com outras secretarias existentes no município", porque acho que secretaria é um órgão maior. Nunca entrei em contato com alguma secretaria para o trabalho com o cadastrado. Eu até pensei, "eu trabalho numa Unidade, deve ter alguma coisa envolvida com outra secretaria", mas não tenho certeza. O ACS passa para o enfermeiro e, o enfermeiro passa para a parceria. Eu não tenho contato. Já a parceria com creches, escolas e outras instituições pra mim, é usar um espaço na igreja para fazer um grupo (educativo) com a comunidade, é uma doação do mercado para uma família carente é, pedir cesta básica na igreja. É ter contato com esta rede comunitária e, conseguir algo para a própria comunidade. Eu tenho um cadastrado que, precisou de alimentação. Junto com a assistente social entramos em contato com o núcleo do idoso e, conseguimos. Se nascer uma criança e o marido abandonar, eu arrumo a parceria. Nas micro-áreas mais carentes, a parceria é sempre bem vinda. Comunico ao enfermeiro e, todos ajudam. Acho muito importante eu ser bem relacionada com meus parceiros.

\section{IC-3: a valorização das ações do ACS pela comunidade}

- Uma parceria foi o curso sobre o meio ambiente que eu tive agora. Diretamente tenho uma ligação (com outras secretarias), quando estou falando (sobre o curso de meio ambiente) através do meu trabalho, também, quando tem alguma campanha com a Secretaria da Saúde. Durante a visita, eu vou uma vez por mês e, vou vendo as outras coisas. Tem essa coisinha aqui que está ruim, mas, tem este lado aqui que é positivo. Ela (cadastrado) não vai ao médico, mas, de repente faz um regime, uma caminhada, dá pra ver o lado bom, o que a pessoa faz de positivo. Pessoas que estão participando do LIANG-GONG (exercício corporal); pode estar o frio que for que elas não desanimam, fico impressionada. As vezes eu me ponho no lugar (do cadastrado). De repente chega alguém na minha casa, mostra tudo que está errado e vai embora. Pelo amor de Deus! Eu coloco sempre alguma coisa de bom. Dou alguma palavra, mostrando que a pessoa faz algo de bom. Uma mãe que comprou o CD pro bebê para a mamada. Isso é positivo! Tinha o tempo certo pra criança. É boa mãe! Foi a coisa mais positiva que vi. 
As análises dos Discursos do Sujeito Coletivo (DSC) identificados no Grupo Focal auxiliaram na identificação da concepção do ACS sobre suas ações de Promoção da Saúde, relacionando-as posteriormente, à prática destas ações, descrito anteriormente.

Os DSC percorrem três Idéias Centrais, sendo a primeira: "O trabalho do ACS".

Diante desse tema encontraram-se três sub-temas, sendo estes: "Dificuldades em quantificar seu trabalho"; "A atividade cotidiana do ACS" e, "Prevenção e Promoção na prática do ACS".

Através da análise desse material é possível observar que este profissional demonstra inabilidade em analisar seu próprio trabalho do ponto de vista das ações. Isso pode ser observado na resposta que a maioria dos sujeitos da pesquisa dá em relação à orientação a gestantes. Esse atendimento na prática ocorre semanalmente e até diariamente, mas ao preencher o formulário, relata como prática mensal.

Esta inabilidade de auto-análise sobre seu trabalho pode revelar pequena proximidade e reflexão entre os aspectos cotidianos de suas ações. Ainda observa-se a limitação de análise do seu cotidiano, quando declara que não existe (freqüência) nunca em seu trabalho, isto é, sempre cumpre com seus deveres e a freqüência raramente só se aplica em algumas ações, demonstrando discordância e recusa em reconhecer esse tipo de ação. Esta negação dificulta o conhecimento e a discussão dos possíveis problemas cotidianos do ACS, mantendo um "tarefismo" sem aprofundar os vários aspectos que envolvem as suas ações.

Com relação ao tema b "A atividade cotidiana do ACS", os discursos dos ACS revelam que existem determinadas situações que lhes geram insegurança quanto as informações dadas, no que se refere às necessidades e dúvidas da comunidade ou família.

Esta observação pode ligar-se ao fato de que determinados questionamento vindos da comunidade podem não fazer parte do conjunto de competências do ACS, ou então, relacionar-se à capacitação insuficiente deste profissional perante suas diversas atribuições. De uma forma ou de outra, o ACS usa dos folhetos informativos 
para suprir sua carência "teórica", se é possível assim se referir, e quando não consegue delimitar, junto a comunidade local seu real papel como ACS.

Aponta-se aqui ao fato do ACS não compreender de forma integral o seu papel, demonstrando dificuldades em visualizar as fronteiras de sua atuação o que faz com que, de certa forma, sinta-se inseguro com o desempenho de seu aporte teórico.

Em um trecho desse mesmo discurso "A atividade cotidiana do ACS", ao tratar do alcoolismo o ACS limita-se às "firmes" orientações contra o vício, como exclusiva estratégia de ação para enfrentar esse problema, deixando de levantar e discutir sobre os diversos determinantes presentes no universo desta doença.

Essa constatação revela que a concepção do ACS sobre o processo saúdedoença, encontra-se fundamentado no lado biologicista hegemônico, não incorporando a esse processo os determinantes sociais, econômicos, culturais entre outros existentes.

Outra revelação encontrada nos discursos é que o ACS idealiza um padrão de comportamento saudável e divide a comunidade em dois grupos, aqueles que se comportam adequadamente e os que não se comportam. Essa concepção idealizada do ACS sobre comportamento saudável pode impedi-lo de fortalecer as competências familiares e da comunidade, ou seja, as habilidades já existentes. O ACS não foca sua ação no que existe de positivo, mas na perspectiva da doença, (mudança de hábito para não ficar doente), da carência, do que falta, distanciando-se da perspectiva da promoção da saúde, que envolve o desenvolvimento da autonomia e consciência do indivíduo e coletividade (seguida de capacitação dirigida) com vistas à tomada de decisões sobre suas necessidades de saúde.

Mais especificamente no sub-tema C: "Prevenção e Promoção na prática do ACS", o sujeito da pesquisa aponta para o desenvolvimento de seus próprios hábitos saudáveis (encarados por ele, como ações de Promoção da Saúde) como uma atitude ainda a ser conquistada em seu aspecto integral. Trata a questão como se as ações de prevenção e promoção não fossem construídas e sim "invadissem" suas vidas, sem sua "permissão", isto é, sem ter refletido ou analisado as implicações dessas ações. 
Quanto a Idéia Central 2, "O desenvolvimento de atividades inter-setoriais", o discurso revela que, o ACS exclui sua responsabilidade, na construção de vias de possibilidades favoráveis, para reunião do Conselho Local de Saúde. Sua expectativa é por uma atividade já delineada e sedimentada, mas como isto não ocorreu (na sua concepção), retira sua participação, sem considerá-la como parte integrante do seu trabalho.

Essa omissão na participação nas reuniões do Conselho Local de Saúde impede que o ACS, desenvolva uma ação moldada na estratégia da Promoção da Saúde. Essa atitude atrapalha o incentivo às ações que visam ao aumento da autonomia individual e coletiva na descoberta de suas reais necessidades de saúde. Como o ACS vai incentivar a participação da comunidade na tomada de decisão no campo da saúde, se ele mesmo não foi transformado por sua prática?

Outro aspecto observado é o direcionamento que o ACS faz em relação aos comportamentos são saudáveis praticados pela comunidade, enfatizando os prejuízos conseqüentes dessa escolha. Com isso, ele perde a oportunidade de construir, junto à comunidade, uma visão positiva sobre a saúde, identificando os porquês das escolhas não saudáveis e podendo traçar, em conjunto com as famílias, meios de desenvolver estilos de vida mais saudáveis.

No que se refere ao apoio do ACS na alfabetização da comunidade assunto da IC-2, a pesquisa demonstra que há apenas a preocupação de indicar o local onde se encontram as instituição educacionais, não demonstrando que a questão tenha sido discutida com o indivíduo e comunidade nos seus demais aspectos.

Mais uma vez, o fortalecimento familiar dá espaço à informação "conteudista", ou seja, à ação sem reflexão, apenas o conteúdo é usado como estratégia para alcançar seu objetivo no trabalho.

A participação e incentivo às ações inter-setoriais foi mais um elemento levantado no IC-2. O ACS aqui investigado se isenta do envolvimento com as ações inter-setorias, destinando ao enfermeiro o "cargo" de responsável ímpar por este papel. O ACS considera como parceria o envolvimento de escolas e creches, o uso de uma sala de aula (da escola ou creche) para grupos informativos de saúde (com a comunidade). Outra parceria, na concepção do ACS, é o envolvimento na área 
comercial, para se obter uma cesta básica, por exemplo, apontando com esta atitude, para uma visão assistencialista e paternalista.

A concepção do ACS sobre a ação que envolve e incentiva a participação inter-setorial, como um dos meios de promover a saúde da comunidade, encontra-se baseada na troca de favores entre os setores, numa visão assistencial e paternalista, não contribuindo, mais uma vez, com o fortalecimento e capacitação das habilidades da comunidade em prol do "incremento do poder técnico e político das comunidades nos processos decisórios para se alcançar melhores níveis de saúde...", segundo eixo de ações da Carta de Ottawa ${ }^{(21)}$.

Por meio da observação do último Discurso do Sujeito Coletivo sobre a Idéia Central-3: "A valorização das ações do ACS pela comunidade", foi possível verificar que o ACS julga desempenhar um potencial favorável na condução da comunidade para o desenvolvimento de estilos de vida saudáveis, potencial esse, superior, na concepção do ACS, ao dos demais profissionais de saúde da equipe.

Diante desse fato percebe-se um profissional que, apesar de não compartilhar integralmente da nova visão da Atenção Básica da Saúde, proposta pela estratégia da Promoção da Saúde, demonstra um potencial favorável para a mobilização da comunidade local. Esse fato comprova que as pesquisas no campo da saúde que tem como sujeito de investigação o ACS, se mostram pertinentes e altamente importantes do ponto de vista de desenvolver pesquisas científicas que proponham estratégias, instrumentos entre outros, para facilitar sua ampla capacitação, envolvendo toda a equipe de saúde nessa complexa e necessária construção. 
CONSIDERAÇÕES FINAIS 


\section{CONSIDERAÇÕES FINAIS}

O presente trabalho considera o método do Materialismo Histórico e Dialético. Este método interpreta os fenômenos sociais de acordo com o modo de produção de uma sociedade. Na compreensão dos autores do referido método, é imprescindível que as forças produtivas (relações estabelecidas entre os homens e a natureza) e as relações de produção (relações que os homens estabelecem entre outros homens) de um grupo social, sejam descritas e analisadas para que, a partir deste ponto, possam ser traçadas as possíveis interpretações do problema ${ }^{(28)}$.

O modo de produção hegemônico da sociedade brasileira é o capitalista periférico, e é a partir da divisão de classes sociais, que se estabelecem as distintas ideologias, responsáveis pela explicação dos problemas sociais. O projeto da burguesia, por exemplo, acredita na naturalização das diferenças sociais, pois entende que a seleção dos mais e menos capacitados, esforçados ou presenteados pela sorte, é melhor para todos. O projeto da pequena burguesia é semelhante ao anterior, com a vantagem da livre competição. O projeto do proletariado, em oposição aos anteriores, tem na participação coletiva dos trabalhadores, entre os vários âmbitos sociais, a forma de assegurar o interesse de todos.

De acordo com Lênin apud Egry e Cubas (2006):

[...] "As classes sociais são grandes grupos de homens que se diferenciam entre si pelo lugar que ocupam em um sistema de produção historicamente determinado, pelas relações em que se encontram frente aos meios de produção (relações que, em grande parte são estabelecidas e formuladas por leis), pelo papel que desempenham na organização social do trabalho $e$, conseqüentemente, pelo modo e proporção pela qual recebem a parte da riqueza social que thes cabe. As classes são grupos humanos nos quais um pode apropriar-se do trabalho do outro, por ocupar postos diferentes em um regime determinado de economia social" [...] ${ }^{(27)}$.

Ao delinear o resultado desta pesquisa, inicialmente no momento da caracterização do ACS observa-se que $100 \%$ do grupo investigado pertencem ao sexo feminino, tornando possível destacar o problema de gênero que, teoricamente, é construído cultural e politicamente. A população estudada encontra-se acima de $60 \%$ 
entre quarenta e cinqüenta e nove anos de idade, considerando uma faixa etária jovem-adulta, em que, possivelmente, as experiências da vida são cronologicamente maiores.

A região e local de nascimento podem ou não influenciar nos costumes de uma população. Entre os sujeitos desta pesquisa, a uniformidade regional e local encontrase em destaque, isto é, $94 \%$ dos ACS nasceram na região sudeste, sendo que $87 \%$ desta na zona urbana. Já no que se refere à origem da população de cadastrados com os quais o ACS trabalha, nota-se que a maioria é da região Nordeste, com costumes diferentes da região Sudeste. Essa diferença de origem pode trazer divergências entre o ACS e os cadastrados em relação à interpretação de um mesmo problema

O estado civil mais destacado entre os ACS é o solteiro, com $47 \%$ de indicações. Se for acrescentado a essa lista os separados (13\%), somar-se-á um total de $60 \%$. A partir desse dado presume-se que a população pesquisada enfrenta os problemas econômicos, considerando o baixo salário deste profissional e a falta de auxilio de um companheiro, acarretando-Ihe a sobrecarga de várias funções para a manutenção de uma casa.

Quanto à escolaridade, o índice de sujeitos da pesquisa que concluíram o ensino médio é de $52 \%$. Esse dado pode esboçar certo nível de desenvolvimento pessoal de forma bastante superficial, pois, o que se observa na prática é que não existe uniformidade de base entre as instituições educadoras de nosso país, o que resulta em diferentes níveis de desenvolvimento pessoal em um mesmo grau de escolaridade. Apesar dessa consideração, é possível constatar que independente das variações entre uma mesma escolaridade, o grau escolar indicado pela maioria dos ACS representa uma diminuição do risco durante a interpretação do formulário das atividades cotidianas do ACS ${ }^{(36)}$.

Uma pequena parcela do grupo pesquisado afirmou ter um curso profissionalizante. Representando $39 \%$ da população investigada relata que freqüentou cursos na área da enfermagem (auxiliar e técnico), vigilante e informática.

Essa formação profissional na área da saúde pode influenciar o ACS, a dar mais importância ao pólo da doença e menos ao pólo da saúde-comunidade, 
dificultando o desenvolvimento de habilidades que auxiliem na formação da autonomia individual e coletiva da comunidade ${ }^{(37)}$.

O tamanho da família do profissional estudado é considerado nesta pesquisa como forma de perceber se as necessidades de consumo de bens materiais correspondem à sua renda familiar.

Descreve-se, então, que 47\% dos profissionais investigados possuem uma renda maior de $R \$ 1.500,00$, sendo distribuída em $41 \%$ dos casos, entre três pessoas,. Isso revela que essa renda familiar supera em aproximadamente $200 \%$ sua renda líquida como Agente Comunitário de Saúde ${ }^{(27)}$.

A condição de moradia também pode influenciar no tipo de consumo de bens materiais dessa população descrita, entendendo que o valor dispensado a esse consumo acarreta um custo elevado, considerando o valor médio empregado aos imóveis desta região. Com 63\% de moradias alugadas é possível interpretar que em média $40 \%$ a $50 \%$ da renda familiar, anteriormente citada, são gastos com moradia, suprimindo os demais débitos individuais e familiares.

O tempo de moradia no local onde trabalha o ACS demarca o possível envolvimento com a população cadastrada. Tem-se que $100 \%$ dos trabalhadores pesquisados trabalham no bairro onde moram e $63 \%$ vivem há mais de quinze anos neste local, um tempo considerado longo para se habituar aos costumes ou estilos de vida da localidade.

Entre as ocupações anteriores ao trabalho de ACS emergem a área administrativa, cuidados infantis e do Lar, ramos de interligação com as atividades de ACS. A experiência anterior com trabalho formal $(87 \%$ com carteira de trabalho assinada) revela que a função atual não inaugura o campo de trabalho formal entre a maioria dos profissionais pesquisados, apontando para um profissional habituado, aparentemente, com a estrutura do trabalho formal.

O profissional investigado revela que $94 \%$ do grupo não possuem outra atividade remunerada, priorizando a atividade de ACS pelo menos no sentido formal. Para 62\% dos entrevistados, a motivação para ser Agente Comunitário de Saúde foi a visualização de uma oportunidade de emprego, já que a função de ACS, na cidade de São Paulo, estende-se por pouco mais de seis anos, tempo insuficiente para formar 
uma referência profissional, positiva ou não, com poder de influenciar na escolha dessa profissão.

Ao ser interrogado sobre a apreciação do trabalho de ACS, obteve-se $100 \%$ das respostas afirmativas. Podem-se traçar duas hipóteses para interpretar essa resposta: primeiro que realmente a função é apreciada pelos profissionais ou segundo, que a resposta negativa poderia acarretar algum tipo de prejuízo ao seu emprego, mesmo que tenha sido esclarecido que esta pesquisa não intenciona obter avaliação de desempenho profissional local.

O tempo de emprego do ACS pode qualificar o trabalho desse profissional. Ao revelar que $50 \%$ dos entrevistados trabalham nessa função entre quatro e seis anos, é possível constatar que provavelmente metade do grupo investigado tenha participado de períodos maiores de capacitação teórico e prático, em comparação com os mais novos contratados,

Quanto ao envolvimento com as atividades comunitárias da localidade, a pesquisa revela que $57 \%$ da população entrevistada participam de grupos religiosos e, por outro lado $0 \%$ dos ACS investigados participam do conselho tutelar.

A caracterização do sujeito desta pesquisa revela aspectos fundamentais que darão suporte para a descrição das atividades do ACS, entre elas as de promoção de saúde, além de analisar essas ações, buscando identificar as concepções que as sustentam.

A análise dos formulários das atividades do ACS usado nesta pesquisa revela que no que se refere ao conjunto das ações do ACS de "Integração da Equipe com a população local", verificou-se que $30,4 \%$ dessas atividades são realizadas diariamente, $35,2 \%$ semanalmente, $27 \%$ mensalmente e $7,4 \%$ raramente.

Os depoimentos colhidos durante o Grupo Focal, após terem sido transformados em discurso do sujeito coletivo, constatam que houve dificuldade, por parte do ACS, em quantificar a freqüência de suas atividades, revelando que a reflexão sobre suas ações, no formato individual e em a equipe, não é aprofundada quantitativamente.

Entre as ações descritas, a mais referida na freqüência raramente foi a ação: "Expõem suas opiniões nas reuniões em equipe" confere que $62,5 \%$ do grupo investigado expõem suas opiniões semanalmente. Se for considerado que, a reunião 
em equipe, neste grupo estudado, acontece uma vez por semana, constata-se que a freqüência ideal para esta ação destacada é, semanal, indicando que uma parcela menor, de $25 \%$, acredita não expor sua opinião diante da equipe de trabalho.

Diante do conjunto das ações de "Planejamento e Avaliação", o segundo eixo de competências do ACS de acordo com o Ministério da Saúde, é possível observar que $11,8 \%$ dessas ações são realizadas diariamente, 32,5\% semanalmente, 34,5\% mensalmente, $16,7 \%$ raramente e 4,5\% nunca são realizadas. Essa distribuição entre as freqüências revela que, apesar de existirem ações em que o peso maior é mensal, a maioria dessas atividades deveria percorrer a freqüência diária. Esse fato demonstra que as ações de avaliação e planejamento do ACS necessitam ser esclarecidas e conferidas por meio de debates em equipe, os quais devem ser programados para explorar o tema, norteando o desenvolvimento de ações claras e bem sedimentadas.

Em relação à descrição do conjunto de ações de Promoção da Saúde, sendo este o terceiro eixo de competências do ACS, é possível observar que 20,15\% dessas ações são realizadas diariamente, 14,22\% semanalmente, $31,22 \%$ mensalmente, $18,97 \%$ raramente e $15,41 \%$ nunca são realizadas.

Ao descriminar cada ação de promoção da saúde compreende-se que determinadas atividades voltadas ao fortalecimento individual e coletivo não fazem parte do cotidiano do ACS. Esse fato foi percebido nos discursos do sujeito coletivo, que mostram a impossibilidade da maioria do grupo estudado em qualificar ou mesmo identificar exemplos positivos dos indivíduos e familiares que promovam a sua saúde.

O Discurso do Sujeito Coletivo (DSC) deixa claro, as dificuldades do ACS em fortalecer as competências individuais e familiares, isto é, as práticas e habilidades já existentes. Estes DSC encontram no tema-c: Prevenção e promoção na prática do ACS, que incorpora a Idéia Central-1: O trabalho de ACS.

O fortalecimento das competências individuais e familiares é interpretado pelo ACS, como uma reação afirmativa por parte dos cadastrados, diante das informações fornecidas pelo ACS, é "colher os frutos" do seu trabalho, a obediência dos cadastrados como recompensa pelo seu esforço. 
A realização de atividades educativas mostra-se em distribuição desigual entre as modalidades: "atividade educativa com o enfermeiro", "atividade educativa com outro ACS" e "atividade educativa sozinho". A terceira modalidade tem uma representação porcentual mais freqüente, considerando que $40 \%$ dos entrevistados referem realizar essa atividade (ação educativa sozinho) mensalmente, apontando para uma ação que, em parte, é compreendida e realizada cotidianamente.

Dirigindo-se ao quarto conjunto de atividades do ACS, as ações de "Prevenção e monitoramento de risco ambiental e sanitário" é possível constatar que $23,75 \%$ dessas ações são realizadas diariamente, 31,25\% semanalmente, 27,5\% mensalmente, $16,25 \%$ raramente e $1,25 \%$ nunca são o são.

Este conjunto de ações encontra-se entre o terceiro eixo de competências do ACS que mais obteve referência pelo sujeito da pesquisa durante o levantamento dos dados quantitativos. Essas ações referem-se a identificar os riscos ambientais e sanitários, informar à equipe de saúde sobre situações de risco na população, informar a população sobre a situação coletiva de saúde e orientar a redução e prevenção dos riscos ambientais e sanitários de saúde. Este grupo de atividades propostas, numericamente reduzido em relação aos outros conjuntos de ações do ACS, não diminui a importância destas ações.

Este grupo de atividades propostas, esquematicamente reduzido, em relação aos outros conjuntos de ações do ACS, não diminui a importância destas ações.

É suposto que, a rotina diária das visitas domiciliares, aguce o olhar do ACS quanto aos riscos ambientais e sanitários, mas, se a importância da observação atenta do ACS ao ambiente não é discutida e planejada entre a equipe, corre-se o risco de naturalizarem-se situações que, a curto ou em médio prazo, necessitem de intervenção.

Baseado nos relatos acima é possível constatar que, o grupo investigado não atua de forma esperada quanto às ações de prevenção e monitoramento de risco ambiental e sanitário, visto que as áreas de risco sanitário e ambiental abrangem a maior parte das áreas de cada uma das três equipes de PSF pesquisadas.

Como forma de complementar essa análise anterior, é necessário recordar também que $24 \%$ do grupo estudado, trabalha como ACS há menos de seis meses, fato que pode contribuir para uma lenta adaptação quanto aos eixos de prioridade do 
seu trabalho. É importante ressaltar que são inúmeras as atribuições do ACS e se não forem devidamente discutidas e refletidas em seu cotidiano, correm o risco de "perderem-se no meio do caminho".

O quinto e último conjunto de ações do ACS, "Prevenção e monitoramento a grupos específicos e morbidades", revela que é o grupo de ações esquematicamente maior entre os cinco eixos de competências do ACS. Este conjunto de ações traça o desenvolvimento de atividades com grupos prioritários do Programa Saúde da Família, delineando de maneira concreta suas atividades.

Com $89,5 \%$ das ações de prevenção e monitoramento a grupos específicos e morbidades, referidas pelo grupo estudado, tem-se o segundo eixo de competências do ACS mais indicado pelo sujeito da pesquisa.

A orientação individual e familiar e, o acompanhamento das morbidades mediante seu grupo de prioridade revela o epicentro deste grupo de ações.

Esse tipo de modalidade é o conjunto de ações que mais se destaca, aquele que requer maior empenho técnico-administrativo, exigindo um tempo para desempenhar as funções burocráticas, igualmente maior. Isto porque ao mencionar "monitoramento" a grupos específicos, se refere ao fato do ACS recolher os dados selecionados pelo Programa referente a cada grupo de morbidade e os lançar concretamente em uma planilha (Ficha-B).

Com semelhante conotação o acúmulo de informações sobre os específicos grupos e morbidades, torna-se fundamental para o sucesso de atuação desse conjunto de ações, convertendo essas atividades em números de produtividade (Ficha-D de produtividade mensal do ACS), podendo aumentar o peso de avaliação em relação aos demais eixos de competência, por dispor de um instrumento de fácil acesso.

Isto pode indicar que os órgãos responsáveis por avaliar o desempenho do trabalho do ACS, tanto no nível local como nacional, selecionam dados quantitativos que tendem destacar atividades do ACS, mais voltadas às ações de prevenção e de monitoramento a grupos específicos e morbidades. Essa avaliação aumenta peso e destaque do trabalho, tanto no âmbito individual deste profissional quanto entre os responsáveis diretos por sua capacitação e avaliação, no caso o enfermeiro. 
Para atingir os objetivos desta pesquisa, correndo o risco de ser repetitiva, mas por necessidade dirijo-me novamente ao conjunto de ações de Promoção da Saúde para mais uma analise, incluindo a explanação descrita anteriormente.

Usando de análise estatística simples, é possível constatar que, na prática, o ACS investigado, não realiza as ações de Promoção da Saúde, de acordo com o que é esperado entre as modalidades, diária, semanal e mensal de cada ação de Promoção da Saúde, decodificado pelo instrumento de Santos (2005) ${ }^{(19)}$.

Essa constatação leva a destacar o que foi anteriormente descrito sobre a crítica ao instrumento de orientação e avaliação do trabalho do ACS, instituído pelo Ministério da Saúde, na forma da Ficha D. Desenvolvida para medir sua produtividade mensal, essa avalia as ações preventivas e de monitoramento a grupos específicos.

Desta forma, para que as mudanças de concepções relativas à promoção da saúde aconteçam torna-se necessário o desenvolvimento de momentos em grupo com toda a equipe de PSF. Esses encontros visam a refletir, planejar e avaliar suas ações de promoção da saúde, tendo como suporte instrumentos desenvolvidos para subsidiar essas discussões e um núcleo de apoio técnico que tenha a intenção de construir ações que promovam a saúde individual e coletiva.

Esse tempo de discussão entre a equipe ou as equipes de PSF de uma determinada Unidade Básica de Saúde deve ser garantido pelos órgãos públicos responsáveis, pois são nesses espaços interativos e integradores que os conceitos de promoção da saúde podem ser coletivamente construídos.

Considera-se ainda de suma importância a capacitação da população no sentido de que essa determine suas necessidades locais de saúde como meta a ser seguida para o alcance das modificações eqüitativas do setor saúde, ação importante em um país com diferenças sócio-econômicas tão alarmantes.

Ao observar as questões iniciais desta pesquisa voltadas a:1 - identificar as ações de promoção da Saúde praticadas pelo ACS, 2 - traçar as concepções do ACS sobre Promoção da Saúde, 3 - localizar em que entendimento de Promoção da Saúde se baseia as concepções do ACS e finalmente, 4 - observar qual a relação entre as concepções de Promoção da Saúde do ACS e sua prática, é possível perceber se os questionamentos norteadores desta pesquisa foram totalmente contemplados, o que será feito a seguir: 
A primeira questão, "identificar as ações de Promoção da Saúde praticadas pelo ACS", foi analisada na parte que se dedicou aos resultados deste trabalho, relatando o conjunto de ações dos cinco eixos de competências do ACS e as indicações feitas pelo ACS sobre todas as ações de promoção da saúde.

As concepções do ACS sobre Promoção da Saúde foram descritas durante as análises dos três Discursos do Sujeito Coletivo, e seu entendimento foi identificado entre as interpretações de Promoção da Saúde, baseadas nos conceitos de Leavell e Clark (1976) ${ }^{(21)}$.

A coerência entre a concepção do ACS sobre as ações de Promoção da Saúde e sua prática cotidiana foi identificada quando estatisticamente a maioria das ações do ACS encontradas, foram aquelas que indicavam orientação a comportamentos saudáveis e monitoramento a grupos de prioridade e morbidades. As concepções sobre essas ações, localizaram-se igualmente, diante de conceitos pré-moldados de comportamento saudável, utilizando-se de informação "conteudista" como única estratégia para tentar solucionar os problemas de saúde.

De maneira geral as práticas e as concepções do ACS sobre as ações de Promoção da Saúde encontram-se sintonizadas, demonstrando que os sujeitos investigados realizam sua prática cotidiana em acordo com as idéias e valores concebidos sobre o seu trabalho.

Outra constatação foi que a capacitação do ACS inicialmente citada durante a implantação do projeto "Janelas", percorreu um tempo delimitado e, por não dar continuidade ao processo, esse profissional não refletiu sobre suas ações, mantendose no modelo biologicista.

A contribuição deste trabalho para a prática da enfermagem no PSF é de extrema importância, pois, ao considerar que o enfermeiro é instrutor/supervisor do trabalho do ACS sendo responsável por sua capacitação e também entender que o instrumento de coleta de dados dessa investigação, o Formulário de Atividades (Anexo-I), poderá fornecer a base para identificar problemas cotidianos relacionados às ações do ACS, julga-se, que com a visualização desses problemas, poderá ser traçado um plano para capacitação do ACS, dirigida especificamente por esses levantamentos. 
Baseado nesta contribuição, esse estudo presente lança um desafio aos profissionais da saúde, principalmente aos enfermeiros, sobre a possibilidade de usar o Formulário de Atividades do ACS (ANEXO-I), como instrumento orientador para as reflexões do trabalho desse profissional (ACS), juntamente com a participação de toda a equipe de saúde. 
REFERÊNCIAS BIBLIOGRÁFICAS 


\section{REFERÊNCIAS BIBLIOGRÁFICAS}

1. Chiesa, AM. A Promoção da Saúde como eixo estruturante do Programa de Saúde da Família. In: Seminário: O Enfermeiro no Programa de Saúde da Família. São Paulo, Secretaria do Estado da Saúde; 2000. [texto de apoio do evento].

2. Chiesa $A M, A$ avaliação da implantação de novos instrumentos para o fortalecimento das ações de promoção do desenvolvimento infantil, na área de atuação do Programa Saúde da Família do Município de São Paulo. Projeto de pesquisa encaminhado as CNPd. eeusp. São Paulo; 2006.

3. São Paulo. Programa saúde da Família, UNICEF, Associação comunitária Monte Azul: Nossas Crianças:Janelas de Oportunidades. Projeto de cooperação. São Paulo; abril de 2002.

4. Ministério da Saúde (BR). Promoção da Saúde. Brasília (DF); 2001-a.

5. Viana ALD, Dal Poz MR, A Reforma do Sistema de Saúde no Brasil e o Programa de Saúde da Família. PHISIS - Revista de Saúde Coletiva 1998; 8 (2): $11-48$

6. Nogueira RP. O trabalho da Agente Comunitário de Saúde: entre a dimensão técnica "universalista" e a dimensão social "comunitarista". Interface 2002; 6 (10): 91-94.

7. Giffin K, Shiraiwa, T. O agente comunitário de Saúde Pública: a proposta de Manguinhos. Cadernos de Saúde Pública. Vol.5. n1. Rio de Janeiro, jan/mar; 1989.

8. Ministério da Saúde (BR). Programa Agentes Comunitários de Saúde (DF); 2001-b.

9. Silva JA, Dalmaso ASW. Agente comunitário de saúde: o ser, o saber, o fazer. Rio de Janeiro: Fiocruz; 2002.

10. Ministério da Saúde (BR). Manual para a organização de atenção básica. Brasília (DF); 1999.

11. Ministério da Saúde (BR). Promoção da saúde: Carta de Ottawa, Declaração de Adelaide, Sundsvall e Santa Fé de Bogotá. Tradução de Luis Eduardo Fonseca. Brasília (DF): Ministério da Saúde; 1996.

12. Ministério da Saúde (BR). Disponível em http://DAB- Atenção Básica- PSFAtenção Primária. 
13. Ferraz L, Aerts Castro DRG. O cotidiano de trabalho do agente comunitário de saúde do PSF de Porto Alegre, ciência e saúde coletiva, vol. 10. n². Rio de Janeiro; 2005.

14. Secretaria de Gestão do Trabalho e da Educação na Saúde Departamento de Gestão da Educação na Saúde. Perfil de Competências Profissionais do Agente Comunitário de Saúde (ACS). Brasília. Out; 2003

15. Trapé CA, Soares CB. A Prática Educativa dos Agentes Comunitários de Saúde à luz da Categoria Práxis. Ver. Latino-Am de Enf. v.15 n.1 Ribeirão Preto: jan/fev; 2007.

16. Bezerra AFB, Santos ACGE, Batista MF. Concepções e Práticas do Agente Comunitário na Atenção à Saúde do Idoso. Ver. Saúde Pública v39 n.5 São Paulo out; 2005.

17. Noronha MGRCS, Resiliência: nova perspectiva na Promoção da Saúde da Família. Ver. Ciências e Saúde Coletiva da ABRASCO; 2006.

18. Santos LPGSS, A atuação do Agente Comunitário de Saúde de São Bernardo do Campo: possibilidades e limites para a promoção da saúde [dissertação] São Paulo (SP): Escola de Enfermagem da USP; 2005.

19. Souza EM, Grundy E. Promoção da Saúde, epidemiologia social e capital social: inter-relações e perspectivas para a saúde pública. Cad. Saúde Pública, Rio de Janeiro, 20(5): 1354-1360, set/out; 2004.

20. Buss P M Promoção de saúde e qualidade de vida: Ciência e Saúde Coletiva, 5(1): 163-177; 2000.

21. Freitas CM. A Vigilância da Saúde para a Promoção da Saúde. In: Czeresnia D, Freitas CM (orgs) Promoção da Saúde: conceitos, reflexões, tendências. Rio de Janeiro: FIOCRUZ; 2003.

22. Nunes ED. Sociologia da Saúde: história e temas: In. Tratado de saúde coletiva. São Paulo: Hucitec; Rio de Janeiro. Ed. Fiocruz; 2006.

23. Vasconcelos CM, Pache DF. O sistema único de saúde. In: Campos GWS, et al (org). Tratado de saúde coletiva. São Paulo: HUCITEC; Rio de Janeiro: FIOCRUZ; 2006.

24. Ministério da Saúde (BR). Política Nacional de Promoção da Saúde. Brasília (DF); 2006.

25. Fortes PAC, Spinett SR. O agente comunitário de saúde e a privacidade das informações dos usuários. Cad. Saúde pública. v.20. Rio de Janeiro. Set/out; 2004.

26. Fonseca. RMGS, et.al. Sociedade e Processo Saúde-Doença do Curso Sistematização da Assistência de Enfermagem com base no Materialismo histórico e dialético. 42ํㅡㄹ Congresso Brasileiro de Enfermagem, Natal (RN), 11 
a 16 de outubro de 1990. In: Egry. EY, Fonseca RMGS. Textos de Apoio. EEUSP. SP; 2004.

27. Egry EY, Cubas MR. $O$ trabalho da enfermagem em saúde coletiva no cenário do CIPESC: ABen. Curitiba; 2006.

28. SIAB. Sistema de informação da atenção básica: Banco de dados da UBS Humaitá: São Paulo; 2008.

29. Secretaria municipal de saúde. Coordenação de Epidemiologia e InformaçãoCElnfo. Dados populacionais região central. Boletim informativo. São Paulo. Disponível em http:// pdf - Adobe Reader; 2005.

30. Secretaria Municipal de Saúde de São Paulo. CEInfo-GISA. UBS Humaitá. [mimeo]. 2007.

31. Vigilância Sanitária-UBS Humaitá. São Paulo. [mimeo]. 2007.

32. Spozati A. Mapa de exclusão/inclusão social da cidade de São Paulo. EDUC/PUC/SP. 2000. disponível em http://www. exclusão social aldaíza spozati.pdf. Adobe Reader. São Paulo.

33. Dall A, Trench MH.Grupos focais como estratégia metodológica em pesquisa na enfermagem. Ver. Gaúcha. Enfermagem. Porto Alegre. V.20. oㅜ 1. p 5-25: jan; 1999.

34. Lefevre F, Lefevre AMC. Depoimentos e discursos: uma proposta de análise em pesquisa social. V. 12. Brasília - DF; 2005.

35. Lefèvre $F$, Lefèvre AMC. O Discurso do Sujeito Coletivo - Um novo enfoque em pesquisa qualitativa (desdobramentos). $1^{\circ}$ ed. Caxias do Sul: EDUCS; 2003.

36. Buther J. Problema de gênero, feminismo e subversão da identidade. Tradução: Renato Aguiar. Rio de Janeiro; 2003.

37. Lefevre $F$, Lefevre AMC. Promoção de saúde a negação da negação. $1^{\text {a }}$ ed.dez: 2004; Rio de Janeiro. 


\section{ANEXOS}




\section{ANEXO I - QUESTIONÁRIO PARA CARACTERIZAÇÃO DO PERFIL DO ACS QUESTIONÁRIO PARA CARACTERIZAÇÃO DO PERFIL DO ACS}

Qual é o seu sexo?

1. ( ) Feminino

2. ( ) Masculino

Qual é a sua idade? anos

Qual a sua raça/cor?

1. ( ) Branca
2. ( ) Preta
3. ( ) Parda
4. ( ) Amarela
5. ( ) Indígena

Qual a sua região de nascimento?

1. ( ) Região Sul (Rio Grande do Sul, Santa Catarina,Paraná)

2. ( ) Região Sudeste (São Paulo, Minas Gerais, Rio de Janeiro, Espírito Santo)

3. ( ) Região Centro-Oeste (Mato Grosso, Mato Grosso do Sul, Goiás, Distrito Federal)

4. ( ) Região Norte (Acre, Amazonas, Roraima, Rondônia, Pará, Amapá, Tocantins)

5. ( ) Região Nordeste (Maranhão , Piauí, Rio Grande do Norte, Ceará, Paraíba, Pernambuco Alagoas Sergipe, Bahia)

Qual o seu local de nascimento?

1. ( ) Zona Rural

2. ( ) Zona Urbana

Qual é o seu estado civil?

1. ( ) Solteiro(a)

2. ( ) Unido(a)

3. ( ) Separado(a)

4. ( ) Viúvo(a)

Qual a última série escolar que você concluiu com aprovação?

CIVIL

Fez algum curso profissionalizante?

1. ( ) Sim

0. ( ) Não

CPROF

Caso a resposta anterior seja afirmativa, escreva o nome do curso realizado:

NCUR

Quantos filhos vivos você possui?

Qual é a sua renda familiar? (total bruto) $\mathrm{R} \$$ 
Você mora em casa:
1. ( ) Própria
2. ( ) Alugada
3. ( ) Cedida
4. ( ) Outros

CASA

Há quanto tempo é morador(a) do bairro onde reside?

MBAIRR

Trabalha no bairro em que mora?

1. ( ) Sim

0. ( ) Não

TBAIRR

Qual era sua ocupação antes de ser Agente Comunitário de Saúde (ACS)?

OCUP

Possuiu carteira assinada antes de ser ACS?

1. ( ) Sim

0. ( ) Não

CART

Realiza alguma outra atividade remunerada além a de ACS?

1. ( ) Sim

0. ( ) Não

ATIVREM

O que primeiramente o(a) motivou a ser ACS?

1. ( ) Gostar da área de saúde

2. ( ) Já conhecia o trabalho do ACS e quis trabalhar nesta área

3. ( ) Gostar de trabalhar com pessoas

4. ( ) Colaborar para melhorar a saúde da comunidade onde vive

5. ( ) Visualizou uma oportunidade de emprego, mesmo não sabendo muito bem o que iria fazer.

6. ( ) Outros. Quais?

Você gosta de trabalhar como ACS?

1. ( ) Sim

0. ( ) Não

GOSTR

Há quanto tempo trabalha no PACS?

TEMTR

Participa ou já participou de alguma atividade na comunidade? (Pode assinalar mais de 01 resposta)

1. ( ) Associação de bairro/moradores

2. ( ) Associação de pais e mestres

3. ( ) Conselho tutelar

4. ( ) Igreja/ comunidade religiosa

5. ( ) Outros. Qual? 
FORMULÁRIO DE ATIVIDADES DO AGENTE COMUNITÁRIO DE SAÚDE

Marque com um "X" a alternativa escolhida

\begin{tabular}{|c|c|c|c|c|c|c|c|}
\hline & & & Freqüênc & com que 1 & aliza & & \\
\hline & Atividade & & $\begin{array}{l}\text { Todos os } \\
\text { dias }\end{array}$ & $\begin{array}{l}\text { Todas as } \\
\text { semanas }\end{array}$ & $\begin{array}{l}\text { Todos os } \\
\text { meses }\end{array}$ & Raramente & Nunca \\
\hline & $\begin{array}{l}\text { Participa das reuniões } \\
\text { em equipe }\end{array}$ & A1 & & & & & \\
\hline & $\begin{array}{l}\text { Expõe suas opiniões } \\
\text { nas reuniões em } \\
\text { equipe }\end{array}$ & A2 & & & & & \\
\hline & $\begin{array}{l}\text { Empenha-se para } \\
\text { executar as ações } \\
\text { propostas pela equipe }\end{array}$ & A3 & & & & & \\
\hline & $\begin{array}{l}\text { Orienta a comunidade } \\
\text { sobre o funcionamento } \\
\text { da UBS, atividades e } \\
\text { campanhas }\end{array}$ & A4 & & & & & \\
\hline $\begin{array}{l}\text { Integração } \\
\text { da equipe } \\
\text { com a }\end{array}$ & $\begin{array}{l}\text { Orienta a comunidade } \\
\text { quanto às ações } \\
\text { desenvolvidas nos } \\
\text { diversos serviços de } \\
\text { saúde } \\
\end{array}$ & A5 & & & & & \\
\hline $\begin{array}{l}\text { população } \\
\text { local } \\
\text { (A) }\end{array}$ & $\begin{array}{l}\text { Traz as necessidades } \\
\text { da comunidade, que } \\
\text { julga pertinente, para } \\
\text { serem discutidas junto } \\
\text { à equipe de saúde }\end{array}$ & A6 & & & & & \\
\hline & $\begin{array}{l}\text { Faz das visitas } \\
\text { domiciliares a base } \\
\text { para o } \\
\text { desenvolvimento das } \\
\text { suas ações como ACS }\end{array}$ & A7 & & & & & \\
\hline & $\begin{array}{l}\text { Preenche a ficha A } \\
\text { (cadastramento) para } \\
\text { todas as famílias } \\
\text { visitadas }\end{array}$ & A8 & & & & & \\
\hline & $\begin{array}{l}\text { Preenche a ficha B } \\
\text { (acompanhamento) } \\
\text { para todos os } \\
\text { indivíduos dos "grupos } \\
\text { de risco" }\end{array}$ & A9 & & & & & \\
\hline & Preenche a ficha $\mathrm{C}$ & A10 & & & & & \\
\hline & $\begin{array}{l}\text { Estimula a população a } \\
\text { participar de conselhos } \\
\text { locais de saúde e/ou } \\
\text { conferências } \\
\text { municipais de saúde }\end{array}$ & B1 & & & & & \\
\hline & $\begin{array}{l}\text { Incentiva a população } \\
\text { a participar de } \\
\text { atividades de sua } \\
\text { própria comunidade }\end{array}$ & B2 & & & & & \\
\hline
\end{tabular}




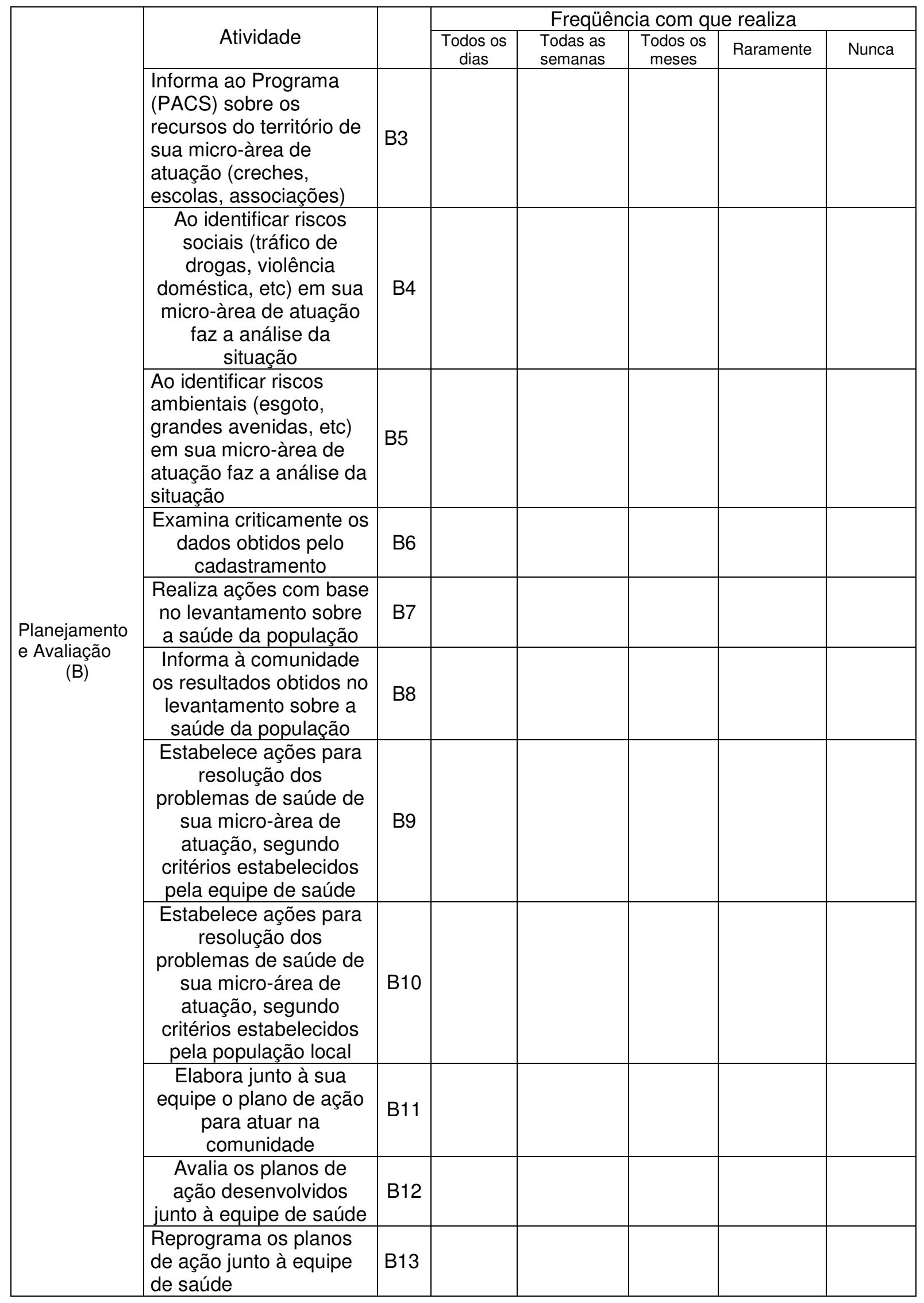




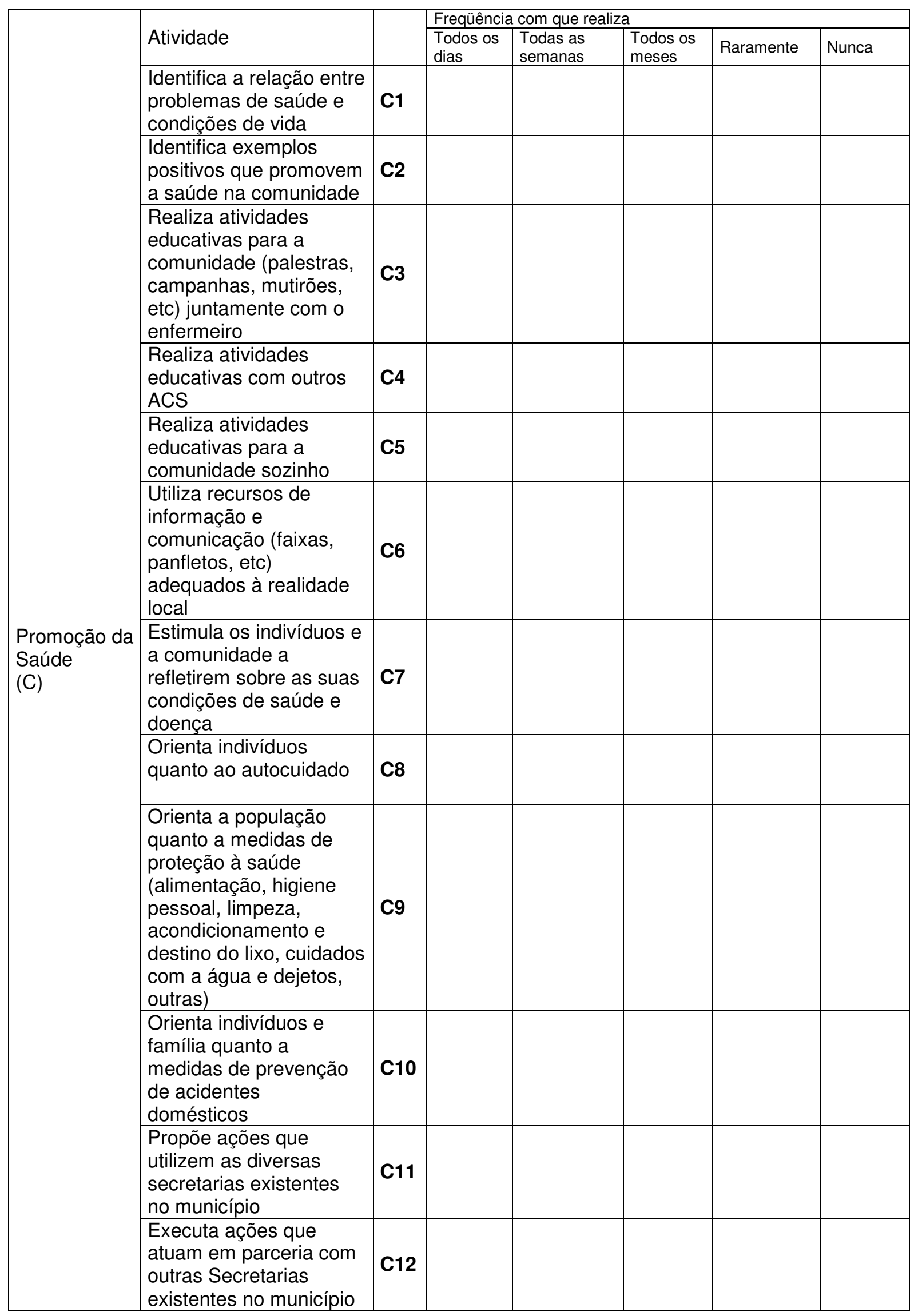




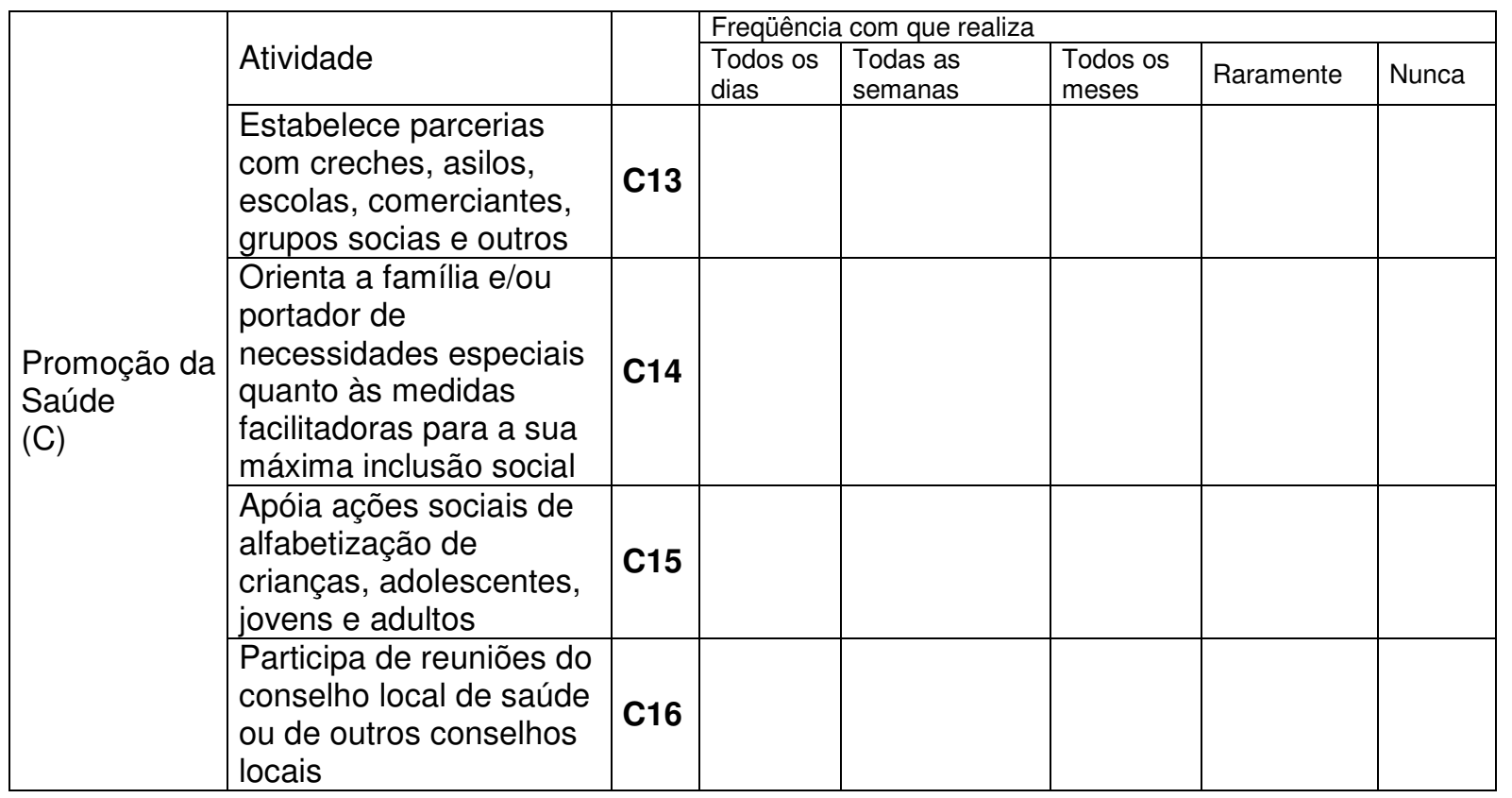

Prevenção e monitoramento de risco ambiental e sanitário (D)

\begin{tabular}{|c|c|c|c|c|c|c|}
\hline \multirow[b]{2}{*}{ Atividade } & & \multicolumn{5}{|c|}{ Freqüência com que realiza } \\
\hline & & \begin{tabular}{|l}
$\begin{array}{l}\text { Todos os } \\
\text { dias }\end{array}$ \\
\end{tabular} & $\begin{array}{l}\text { Todas as } \\
\text { semanas }\end{array}$ & $\begin{array}{l}\text { Todos os } \\
\text { meses }\end{array}$ & Raramente & Nunca \\
\hline $\begin{array}{l}\text { Identifica as } \\
\text { condições ambientais } \\
\text { e sanitárias que } \\
\text { provoquem riscos } \\
\text { para a saúde da } \\
\text { comunidade }\end{array}$ & D1 & & & & & \\
\hline $\begin{array}{l}\text { Informa à equipe de } \\
\text { saúde sobre a } \\
\text { ocorrência de } \\
\text { situações de risco, na } \\
\text { micro-área de atuação }\end{array}$ & D2 & & & & & \\
\hline $\begin{array}{l}\text { Informa à população } \\
\text { sobre a ocorrência de } \\
\text { situações de risco, na } \\
\text { micro-área de atuação }\end{array}$ & D3 & & & & & \\
\hline $\begin{array}{l}\text { Orienta indivíduos e } \\
\text { grupos quanto a } \\
\text { medidas de redução } \\
\text { ou prevenção de } \\
\text { riscos ambientais e } \\
\text { sanitários em saúde }\end{array}$ & D4 & & & & & \\
\hline $\begin{array}{l}\text { Orienta moradores e } \\
\text { famílias quanto aos } \\
\text { cuidados relacionados } \\
\text { ao ambiente } \\
\text { hospitalar }\end{array}$ & D5 & & & & & \\
\hline $\begin{array}{l}\text { Identifica indivíduos } \\
\text { ou grupos que } \\
\text { demandam cuidados } \\
\text { especiais de saúde }\end{array}$ & E1 & & & & & \\
\hline
\end{tabular}




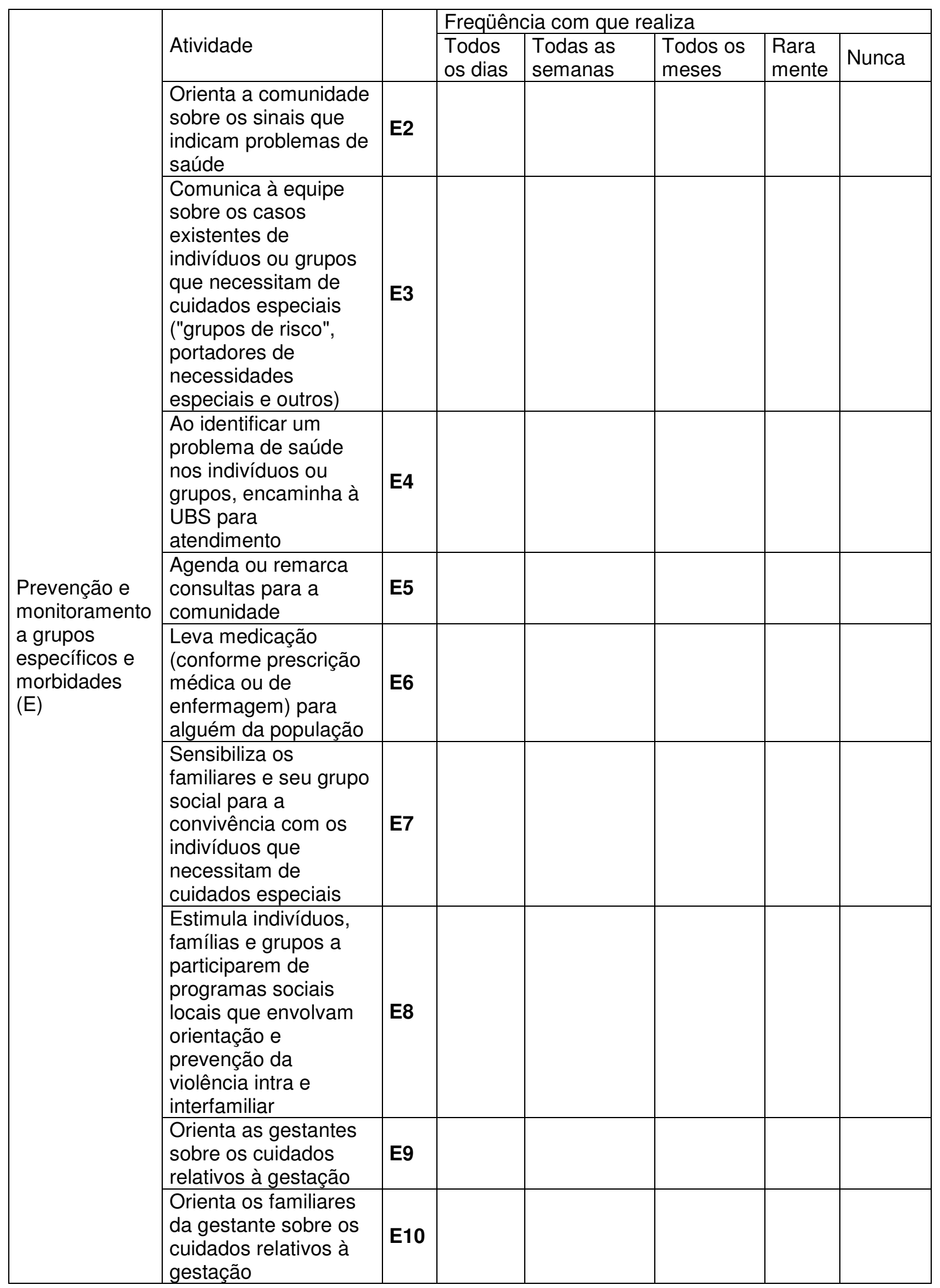




\begin{tabular}{|c|c|c|c|c|c|c|c|}
\hline & & & Freqüêr & cia com qu & aliza & & \\
\hline & Atividade & & \begin{tabular}{|l|} 
Todos \\
os dias \\
\end{tabular} & $\begin{array}{l}\text { Todas as } \\
\text { semanas } \\
\end{array}$ & $\begin{array}{l}\text { Todos os } \\
\text { meses }\end{array}$ & \begin{tabular}{|l|} 
Rarame \\
nte
\end{tabular} & Nunca \\
\hline & $\begin{array}{l}\text { Orienta as gestantes } \\
\text { sobre os cuidados } \\
\text { relativos ao parto }\end{array}$ & E11 & & & & & \\
\hline & $\begin{array}{l}\text { Orienta os familiares } \\
\text { da gestante sobre os } \\
\text { cuidados relativos ao } \\
\text { parto }\end{array}$ & E12 & & & & & \\
\hline & $\begin{array}{l}\text { Orienta as gestantes } \\
\text { sobre os cuidados } \\
\text { relativos ao puerpério }\end{array}$ & E13 & & & & & \\
\hline & $\begin{array}{l}\text { Orienta os familiares } \\
\text { da gestante sobre os } \\
\text { cuidados relativos ao } \\
\text { puerpério }\end{array}$ & E14 & & & & & \\
\hline & $\begin{array}{l}\text { Orienta gestantes, } \\
\text { puérperas e grupo } \\
\text { familiar quanto ao } \\
\text { aleitamento materno }\end{array}$ & E15 & & & & & \\
\hline Prevenção e & $\begin{array}{l}\text { Orienta gestantes, } \\
\text { puérperas e grupo } \\
\text { familiar quanto aos } \\
\text { cuidados com o } \\
\text { recém-nascido }\end{array}$ & E16 & & & & & \\
\hline morbidades & $\begin{array}{l}\text { Solicita o passaporte } \\
\text { materno-infantil nas } \\
\text { visitas domiciliares }\end{array}$ & E17 & & & & & \\
\hline & $\begin{array}{l}\text { Orienta indivíduos } \\
\text { quanto à saúde sexual } \\
\text { e reprodutiva }\end{array}$ & E18 & & & & & \\
\hline & $\begin{array}{l}\text { Acompanha o } \\
\text { crescimento infantil }\end{array}$ & E19 & & & & & \\
\hline & \begin{tabular}{|l} 
Acompanha o \\
desenvolvimento \\
infantil
\end{tabular} & E20 & & & & & \\
\hline & $\begin{array}{l}\text { Solicita o cartão de } \\
\text { vacina das crianças } \\
\text { nas visitas } \\
\text { domiciliares }\end{array}$ & E21 & & & & & \\
\hline & \begin{tabular}{|l|} 
Orienta indivíduos e \\
famílias sobre as \\
medidas de \\
prevenção e controle \\
das doenças não \\
transmissíveis
\end{tabular} & E22 & & & & & \\
\hline & $\begin{array}{l}\text { Orienta indivíduos e } \\
\text { famílias sobre as } \\
\text { medidas de } \\
\text { prevenção e controle } \\
\text { das doenças } \\
\text { transmissíveis }\end{array}$ & E23 & & & & & \\
\hline
\end{tabular}




\section{ANEXO II - TERMO DE CONSENTIMENTO LIVRE E ESCLARECIDO}

\section{CONSENTIMENTO LIVRE E ESCLARECIDO}

Título da Pesquisa: As concepções do Agente Comunitário de Saúde sobre Promoção da Saúde

Pesquisadora responsável: Eugênia Zilioli de Almeida

Orientador: Lislaine Aparecida Fracolli

1. O estudo a que se refere este consentimento livre e esclarecido tem caráter investigativo e é referente a uma pesquisa de mestrado da Escola de Enfermagem da Universidade de São Paulo (EEUSP)

2. O estudo tem por objetivo identificar e descrever as ações de promoção do ACS com base nas competências do Ministério da Saúde e analisar as ações relacionadas à competência da Promoção da Saúde, buscando identificar as concepções que dão suporte a essas ações.

3. Como procedimentos metodológicos os dados serão coletados a partir da aplicação de um questionário para a caracterização dos ACS e um formulário que buscará identificar as ações que este profissional realiza, bem como a freqüência com a qual executa essas ações. A seguir essas informações serão qualificadas através da percepção dos próprios ACS.

4. Os ACS terão liberdade para manifestar-se, poderão fazer qualquer questionamento acerca do estudo e de sua participação, devendo ser esclarecido sobre suas dúvidas em qualquer momento da pesquisa. Garante-se o sigilo acerca da identidade do informante e sua participação é voluntária, ou seja, seu nome não será divulgado em nenhum momento do estudo, tendo o sujeito da pesquisa toda a liberdade de recusar-se a participar do estudo, sem que isso represente qualquer prejuízo, desconforto ou risco à sua pessoa ou ao desempenho de seu trabalho.

5. Todas as informações obtidas através do questionário e formulário deverão ser mantidas sob sigilo e em lugar seguro.

6. Os resultados deverão ser descritos e analisados em um relatório formal que, ao seu término será apresentado publicamente, aos ACS as quais se refere 0 estudo e em instancias publicas como congressos, periódicos e afins.

7. Maiores esclarecimentos poderão ser obtidos com a pesquisadora responsável Eugênia Zilioli de Almeida - fone: (11) 31297132 ou (11) 96742999 e com a orientadora da pesquisa Lislaine Aparecida Fracolli - fone: (11) 3066 - 7652 ou com o Comitê de Ética em Pesquisa da Prefeitura Municipal de São Paulo - fone: (11) 32184043.

Declaro que, após convenientemente esclarecido pela pesquisadora responsável e de ter compreendido com clareza suas finalidades, procedimentos metodológicos e o destino final das informações recolhidas, consinto em participar livremente do estudo a que se refere este consentimento informado. 
São Paulo,... de. de 2007.

Assinatura do ACS

Assinatura do pesquisador 